\title{
norden
}

Nordisk ministerråd

Effektive strategier for livslang læring i de nordiske lande 



\section{Effektive strategier for livslang læring i de nordiske lande}

Forfattere: Søren Ehlers, Gun-Britt Wärvik, Anne Larson og Per-Olof Thång

Redaktør: Tinne Geiger

TemaNord 2011:561 


\section{Effektive strategier for livslang læring i de nordiske lande}

Forfattere: Søren Ehlers, Gun-Britt Wärvik, Anne Larson og Per-Olof Thång

Redaktør: Tinne Geiger

TemaNord 2011:561

ISBN 978-92-893-2277-5

(c) Nordisk Ministerråd, København 2011

Tryk: Kailow Express ApS

Oplag: 300

Denne rapport er udgivet med finansiel støtte fra Nordisk Ministerråd. Indholdet i rapporten afspejler dog ikke nødvendigvis Nordisk Ministerråds synspunkter, meninger, holdninger eller anbefalinger.

Printed in Denmark

\section{Det nordiske samarbejde}

Det nordiske samarbejde er en af verdens mest omfattende regionale samarbejdsformer. Samarbejdet omfatter Danmark, Finland, Island, Norge og Sverige samt Færøerne, Grønland og Åland.

Det nordiske samarbejde er både politisk, økonomisk og kulturelt forankret, og er en vigtig medspiller i det europæiske og internationale samarbejde. Det nordiske fællesskab arbejder for et stærkt Norden i et stærkt Europa.

Det nordiske samarbejde ønsker at styrke nordiske og regionale interesser og værdier i en global omverden. Fælles værdier landene imellem er med til at styrke Nordens position som en af verdens mest innovative og konkurrencedygtige regioner.

\section{Nordisk Ministerråd}

Ved Stranden 18

1061 København K

Telefon (+45) 33960200

\section{www.norden.org}




\section{Indhold}

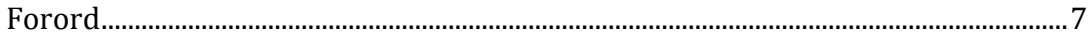

Effektive strategier for livslang læring i de nordiske lande....................................

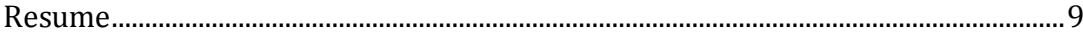

Samarbejdet mellem myndigheder og arbejdsmarkedets parter........................9

Samspillet mellem uddannelsesinstitutioner og virksomheder ..........................10

Indsatser for at styrke voksnes nøglekompetencer ............................................... 10

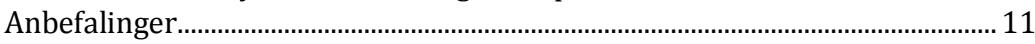

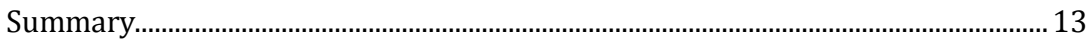

The cooperation between authorities and social partners................................... 14

The interaction between education providers and businesses............................ 14

Efforts to strengthen adults' competences ...........................................................15

Recommendations ............................................................................................ 16

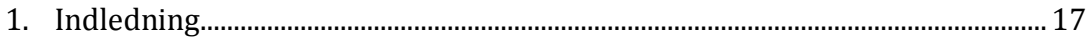

$1.1 \quad$ Formål.................................................................................................. 17

1.2 Undersøgelsesmetode.............................................................................. 18

1.3 Begrebsafklaring..................................................................................... 19

2. Den kompetencepolitiske indsats siden 2000 ....................................................23

2.1 Danmark ............................................................................................ 23

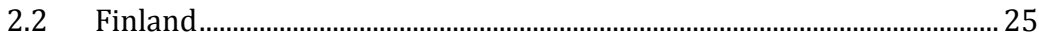

2.3 Island ......................................................................................................... 28

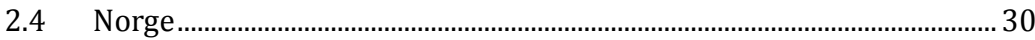

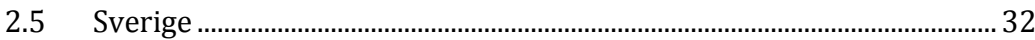

3. Udviklingen af nationale strategier ................................................................... 35

3.1 Samarbejdet mellem myndigheder og arbejdsmarkedets parter .......... 35

3.2 Indholdet i de nationale strategier, herunder særlige

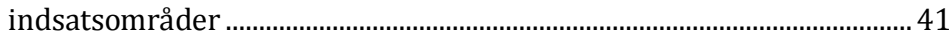

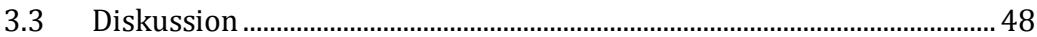

3.4 Delkonklusion med anbefalinger ................................................................. 49

4. Samspillet mellem uddannelsesinstitutioner og virksomheder .........................51

4.1 Uddannelsessystem vs. arbejdsliv ..............................................................51

4.2 Rådgivning.................................................................................................... 55

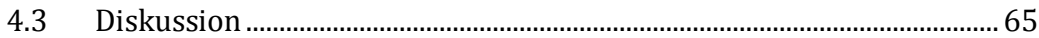

4.4 Delkonklusion med anbefalinger ................................................................ 66

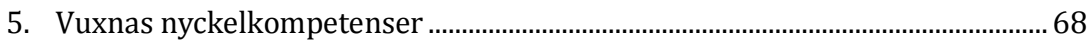

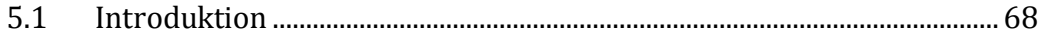

5.2 Nyckelkompetenser i de nordiska länderna .............................................. 73

5.3 Diskussion ................................................................................................... 81

5.4 Delkonklusion med rekommendationer .................................................... 82 


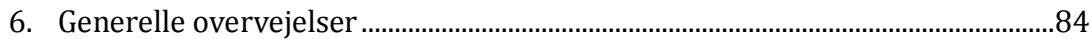

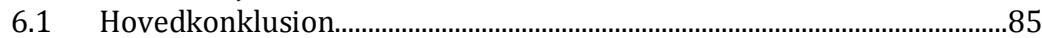

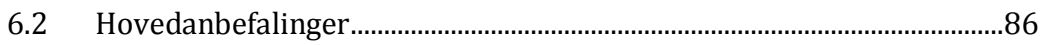

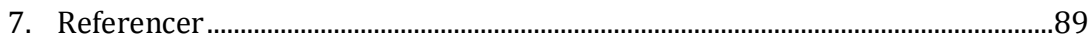

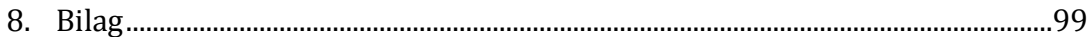

8.1 Oversigt over det ordinære uddannelsessystem i Danmark ..................99

8.2 Oversigt over voksen- og efteruddannelsessystemet i Danmark ....... 100

8.3 Oversigt over uddannelsessystemet i Finland ........................................ 101

8.4 Oversigt over uddannelsessystemet i Island ........................................... 102

8.5 Oversigt over uddannelsessystemet i Norge ........................................... 103

8.6 Oversigt over uddannelsessystemet i Sverige ....................................... 104

8.7 Oversigt over forkortelser.......................................................................... 105

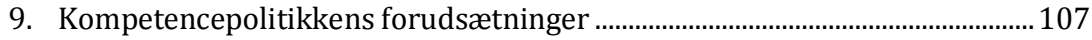

9.1 Danmark 107

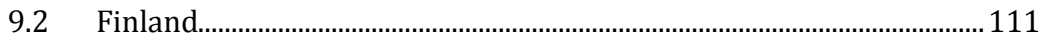

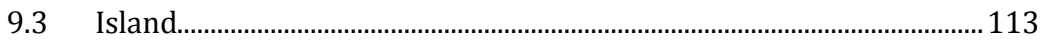

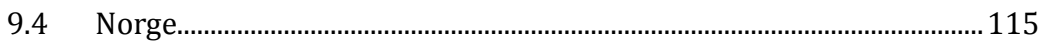

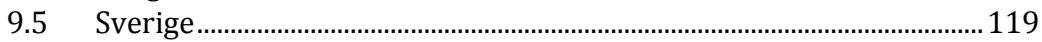

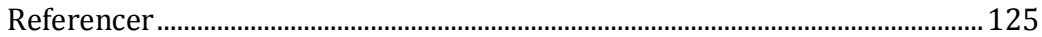




\section{Forord}

\section{Effektive strategier for livslang læring i de nordiske lande}

De nordiske lande har en lang tradition for livslang læring for voksne, der omhandler både folkeoplysning, almen og erhvervsrettet voksen- og efteruddannelse. Det er centralt for de nordiske lande, at den kompetencepolitiske indsats for at fremme livslang læring imødekommer både arbejdsmarkedets kompetencekrav og det moderne samfunds behov for sammenhængskraft.

Under Nordisk Ministerråds globaliseringsprojekt „En god uddannelse til unge og voksne" har ministerrådet derfor sat fokus på, hvad der gøres for at fremme voksnes deltagelse i livslang læring, dels gennem udvikling af partnerskaber mellem især myndigheder og arbejdsmarkedets parter, dels mellem virksomheder og uddannelsesinstitutioner.

Studiet om effektive strategier for livslang læring har til formål at skabe overblik over de nordiske landes indsatser for at fremme livslang læring for alle, herunder ikke mindst kortuddannede på arbejdsmarkedet samt vise "best pratice“ med henblik på erfaringsudveksling og fælles nordiske drøftelser.

Studiet har blandt andet vist, at de nordiske strategier for livslang læring har opnået en vis overensstemmelse siden 2001. Blandt fællestrækkene kan nævnes at:

- Der er samarbejde mellem de uddannelsespolitiske og de arbejdsmarkedspolitiske myndigheder: Et udtryk for voksenuddannelsens øgede betydning som arbejdsmarkedspolitisk redskab.

- Der er et øget fokus på realkompetencer og på vejledning og rådgivning.

- Der er en tendens til at landene går i retning af mere offentlig regulering og frivillig koordinering.

- De nordiske lande vurderer alle, at deres nationale læreplaner følger EUs anbefalinger til nøglekompetencer, om end de for størsteparten er udarbejdet inden vedtagelsen af nøglekompetencer. 
Nationalt Center for Kompetenceudvikling (NCK) under Aarhus Universitet har udarbejdet rapporten på opdrag af ministerrådet. NCK vandt opgaven i et åbent udbud blandt analyseinstitutioner og fagmiljøer ved højere læreanstalter og universiteter i Norden.

Vi håber, at rapporten kan skabe grundlag for frugtbare diskussioner om de nordiske landes indsatser for at fremme livslang læring for alle samt være til inspiration og læring for alle, der arbejder med dette felt.

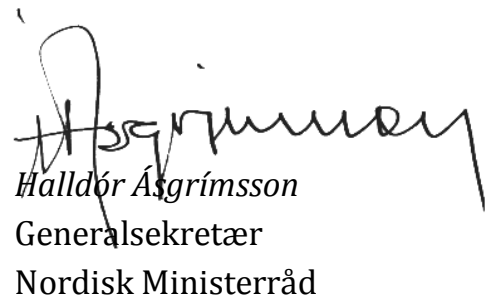




\section{Resume}

Dette studie af effektive strategier for livslang læring i de nordiske lande fokuserer på tre områder:

- Samarbejdet mellem myndigheder og arbejdsmarkedets parter

- Samspillet mellem uddannelsesinstitutioner og virksomheder

- Indsatser for at styrke voksnes nøglekompetencer

De nordiske landes strategier inden for livslang læring er i god overensstemmelse med de retningslinier, der fremgår af EUs Lissabonstrategi som blev vedtaget af EU i 2000. Generelt kan det siges, at det måske snarere er de nordiske lande, der inspirerer såvel EUs som OECDs politik på området end det modsatte. De nordiske lande må betragtes som foregangslande inden for livslang læring. Det er således et fællestræk for alle de nordiske lande, at en stor del af den voksne befolkning har adgang til og deltager i formaliseret og ikke-formaliseret kompetenceudvikling.

De nordiske landes strategier for livslang læring har siden 2001 opnået en vis overensstemmelse, også inden for de tre nævnte områder. Denne bevægelse mod større ensartethed, gør komparative studier inden for området relevante.

\section{Samarbejdet mellem myndigheder og arbejdsmarkedets parter}

Fælles for de fem lande i forhold til relationen mellem myndigheder og arbejdsmarkedets parter er blandt andet at:

- Arbejdsmarkedets parter er inddraget i såvel politikudformning som implementering

- Der er samarbejde mellem de uddannelsespolitiske og de arbejdsmarkedspolitiske myndigheder, et udtryk for voksenuddannelsens øgede betydning som arbejdsmarkedspolitisk redskab 
- I overensstemmelse med Lissabonstrategien er der et ønske om at øge deltagelsen i voksenuddannelse yderligere, særligt blandt kortuddannede og tosprogede

- Der er et øget fokus på realkompetencer og på vejledning og rådgivning

Landene adskiller sig primært i præsentationen af strategier og planer for livslang læring. Mens der i nogle lande findes samlede strategier med eksplicit fokus på livslang læring, så er der i andre lande ikke tale om en overordnet strategi, men snarere en række strategier og reformer, hvor livslang læring og voksenuddannelse indgår som et element.

\section{Samspillet mellem uddannelsesinstitutioner og virksomheder}

Gennem det seneste årti har de nordiske lande fortrinsvis forstået området som et marked præget af udbud og efterspørgsel. Det er fælles for de nordiske lande, at denne tænkning er ved at blive svækket til fordel for stigende offentlig regulering og regional koordinering.

Norge er det eneste land, hvor markedet er udbudsstyret, idet uddannelsesinstitutionernes aktivitet afhænger af kommunale og regionale budgetter. I de øvrige lande er markedet primært efterspørgselsstyret, dog som nævnt - med regulerende tiltag i næsten alle landene. Både Danmark og Finland har i 2010 implementeret tiltag i form af oprettelsen af henholdsvis VEU-centre og TE-centraler, der øger regulerings- og koordineringsmulighederne. Da initiativerne er helt nye, er det endnu ikke muligt at vurdere deres effekt.

Det forventes, at bevægelsen væk fra en tænkning i marked mod en tænkning i offentlig regulering og frivillig koordination vil kunne forbedre vilkårene for samspillet mellem udbydere og virksomheder.

\section{Indsatser for at styrke voksnes nøglekompetencer}

Studiet af indsatser til styrkelse af voksnes nøglekompetencer tager udgangspunkt i EUs anbefalinger til otte nøglekompetencer inden for livslang læring, som med udgangspunkt i Lissabonstrategien blev vedtaget $\mathrm{i}$ 
2006. Kompetencerne omfatter kompetence til at kommunikere på modersmål og på fremmedsprog, matematiske, tekniske og digitale kompetencer, læringskompetence, interpersonelle, interkulturelle og sociale kompetencer, iværksætterevne og kulturel udtryksevne.

Det er fælles for de nordiske lande at:

- De nationale læreplaner i de fleste tilfælde er udarbejdet inden vedtagelsen af anbefalingerne til nøglekompetencer

- Indholdet i de nationale læreplaner til trods herfor stemmer godt overens med anbefalingerne ifølge landene selv

På den baggrund sluttes det, at EUs anbefalinger har haft begrænset indflydelse i de nordiske lande, som dog alle selv vurderer, at de lever op til anbefalingerne.

De nordiske lande lægger stort set alle vægt på satsninger, der er rettet mod mere grundlæggende færdigheder som læse-, skrive-, regne og kommunikative færdigheder, kompetencer der betragtes som centrale for at kunne få eller beholde et arbejde.

Dette går igen i de projekter, som hvert af de nordiske lande har igangsat inden for området. Der er tale om konkrete projekter, som landene har rapporteret til EU som projekter, der skal bidrage til at opfylde EUs anbefalinger. Det er således typisk for de projekter, der er rettet mod voksne at:

- De fokuserer på kommunikative færdigheder

- De er rettet mod kompetencer, der kræves for at få eller beholde et arbejde

\section{Anbefalinger}

På baggrund af ovenstående opstilles i det følgende en række anbefalinger af studier og analyser. Baggrunden for anbefalingerne er det forhold, at landene er ved at opnå en vis overenstemmelse mht. strategier for livslang læring, og dette gør komparative studier relevante. Konkret anbefales det at igangsætte komparative studier af:

- Nationale og regionale strategier, der modvirker marginalisering og understøtter kortuddannede i forhold til arbejdsliv og samfundsliv 
- Formuleringen samt effekten af regionale strategier for livslang læring og mobilitet

- Samspillet mellem nationale, regionale og lokale myndigheder i det konkrete samarbejde med udbydere, virksomheder og arbejdsmarkedets parter

- Udbydernes, virksomhedernes og arbejdsmarkedets parters erfaringer med den konkrete anvendelse af NQFs

- De nordiske landes indsats for kortuddannede, der vil kunne give andre lande kendskab til de nordiske modeller 


\section{Summary}

\section{Effective lifelong learning strategies in the Nordic countries}

The Nordic Council of Ministers has initiated this comparative study of the political efforts to promote lifelong learning for all, including low-skilled labor, in the Nordic countries. The aim is to provide an overview of the political efforts and to create a basis for specific comparisons in order to support mutual inspiration and learning among the Nordic countries.

The study is based on the Nordic countries' development and implementation of political initiatives in three main areas concerning competence development:

- The cooperation between authorities and social partners on adult and continuing education initiatives

- The interaction between providers and businesses including guidance on adult and continuing education and competence development, and

- Efforts to strengthen adults' key competencies in relation to participation on the labor market and in society

Within each area the study examines selected examples of actual practice and provides recommendations of further studies and analysis.

The Nordic countries' strategies for lifelong learning is in good accordance with the guidelines set out by the EU's Lisbon Strategy adopted by the EU in 2000. One might say that the Nordic countries inspire EU policies as well as OECD policies in the area rather than the other way around. The Nordic countries might be considered frontrunners within the area of lifelong learning. It is hence a common feature for all the Nordic countries, that a large proportion of the adult population has access to and participates in formal and non-formal competence development.

Since 2001 the Nordic countries' strategies for lifelong learning have acquired a certain consistency, also within the three areas. This movement 
toward greater uniformity, is making comparative studies in the field relevant.

\section{The cooperation between authorities and social partners}

Regarding the relationship between authorities and social partners it is among others common to the five Nordic countries that:

- Social partners are involved in both policy formulation and implementation concerning adult and continuing education

- The authorities of education policy and of social policy cooperate, an expression of the increased importance of adult education as a social policy tool

- In line with the Lisbon strategy there is a desire to increase participation in adult education further, particularly among low-skilled and bilingual

- There is an increased focus on prior learning and on guidance and counseling

The five countries differ mainly in the presentation of strategies and plans for lifelong learning. While some countries present overall strategies focusing explicit on lifelong learning, other countries do not have one overall strategy, but rather a series of strategies and reforms, where lifelong learning and adult education is included as one item.

\section{The interaction between education providers and businesses}

During the past decade the Nordic countries have mostly understood the field of lifelong learning as a market characterized by supply and demand. It is common for the Nordic countries that thinking is being weakened in favor of increasing government regulation and regional coordination.

Norway is the only country where the market is supply-driven since education institutions' activity depends on local government budgets. In the other countries, the market is primarily demand driven, however - as 
mentioned - with regulatory initiatives in almost all countries. Both Denmark and Finland have in 2010 implemented initiatives in terms of establishing VEU-centers and TE-centrals respectively, which increases regulatory and coordination opportunities. Because the initiatives are quite new, it is not yet possible to assess their impact.

It is expected that the movement away from thinking in a market against a thinking in government regulation and voluntary coordination could improve the conditions for interaction between education providers and businesses.

\section{Efforts to strengthen adults' competences}

The study of efforts to strengthen adults' key competences is based on EU recommendations on eight key competences for lifelong learning, based on the Lisbon Strategy and adopted in 2006. The competencies include the competence to communicate in mother tongue and in foreign languages, mathematical, technical and digital skills, learning skills, interpersonal, intercultural and social competences, entrepreneurship and cultural expression.

It is common for the Nordic countries that:

- The national curricula in most cases are prepared before the adoption of recommendations on key competences

- The contents of the national curricula despite this correspond well with the EU recommendations, according to the Nordic countries themselves

Against this background it is reasonable to suggest that the EU recommendations have had limited influence in the Nordic countries, although the countries, according to themselves, all adhere to the recommendations.

The Nordic countries all emphasize initiatives that are directed toward more basic skills such as literacy, numeracy and communication skills, competences that are considered key to get or keep a job.

This is reflected in the projects that each of the Nordic countries have launched within the area. These are specific projects which the countries have reported to the EU as projects to help meet the EU recommendations. It is hence typical of the projects aimed at adults that: 
- They focus on communicative skills

- They are directed at skills needed to get or to keep a job

\section{Recommendations}

Based on the foregoing, the present study reaches a series of recommendations for future studies and analysis. As mentioned, it is assessed that the still more common features of the Nordic countries makes it increasingly more meaningful to conduct comparative studies in this area. Specifically, it is recommended to initiate comparative studies of:

- National and regional strategies to counteract the marginalization and supports low-skilled in relation to working life and society

- The formulation and the effect of regional strategies for lifelong learning and mobility

- The interaction between national, regional and local authorities in concrete cooperation with providers, enterprises and social partners

- Providers', enterprises' and social partners experience with the practical application of NQFs

- The Nordic countries' efforts for low-skilled, which could provide other countries knowledge of the Nordic models 


\section{Indledning}

\subsection{Formål}

De nordiske lande er alle kendetegnet ved, at en høj andel af befolkningen deltager i voksenuddannelse sammenlignet med andre lande i OECD. Det var en af konklusionerne i rapporten „Nyfikna sinnen - Nordisk vuxenutbildning i jämförelse“ (Nordisk Ministerråd, 2001a), som samtidig pegede på store forskelle mellem de nordiske landes strategier for livslang læring. Mens Finland tog princippet om livslang læring til sig straks efter OECD's offentliggørelse af rapporten „Lifelong learning for all“ i 1996, og offentliggjorde en national strategi for livslang læring i 1997, offentliggjorde Danmark sin nationale strategi i 2007.

Udviklingen og implementeringen af effektive strategier afhænger af samarbejdet mellem myndigheder og arbejdsmarkedets parter og samspillet mellem uddannelsesinstitutioner og virksomheder. Det er derfor interessant at undersøge disse relationer med henblik på at analysere, hvorledes disse relationer kan være med til at fremme voksnes deltagelse i livslang læring.

På den baggrund har Nordisk Ministerråd taget initiativ til et komparativ studie. Studiet beskæftiger sig med de nordiske landes formulering og implementering af kompetencepolitiske tiltag inden for livslang læring for alle, herunder kortuddannede på arbejdsmarkedet. Undersøgelsen skal, udover at skabe overblik over de kompetencepolitiske indsatser, danne grundlag for konkrete sammenligninger samt erfaringsudveksling med henblik på gensidig inspiration og læring mellem de nordiske lande.

Undersøgelsen er bygget op om de nordiske landes udvikling og implementering af kompetencepolitiske initiativer inden for tre primære områder:

- Samarbejdet mellem myndigheder og arbejdsmarkedets parter om voksen- og efteruddannelsespolitiske tiltag og initiativer

- Samspillet mellem uddannelsesinstitutioner og virksomheder, herunder rådgivning om voksen- og efteruddannelse og kompetenceudvikling 
- Indsatser for at styrke voksnes nøglekompetencer i forhold til deltagelse på arbejdsmarkedet og i samfundslivet

Inden for hvert område, vil studiet undersøge udvalgte eksempler fra den konkrete praksis og desuden levere anbefalinger studier og analyser.

\subsection{Undersøgelsesmetode}

Undersøgelsen af strategierne for livslang læring i de fem nordiske lande er overvejende baseret på analyse af policypapirer og andre relevante dokumenter. Desuden er der suppleret med interview med udvalgte repræsentanter for uddannelsesområdet (ministerier og/eller interessenter i relation til voksenuddannelse) i de fem lande. Endelig har en foreløbig udgave af rapporten været læst og kommenteret af nationale repræsentanter for opdragsgiver inden den endelige udarbejdelse.

\subsubsection{Dokumentanalyser samt litteraturstudier}

Dokumentanalysen har fokuseret på strategier og planer for udviklingen af voksenuddannelsessystemet med henblik på de konkrete idéer og planer, baggrunden for disse, samt hvilke aktører, der har været involveret i planlægningen og tænkes involveret i implementeringen af planerne. I forbindelse med sidstnævnte har der været et særligt fokus på, hvilken rolle uddannelsesinstitutioner og virksomheder tænkes at have. Studiet undersøger desuden de nationale strategier og planers relation til de transnationale policies, som især EU udvikler. Andre vigtige initiativer har været EQF (European Qualifications Framework), der i 2004 blev vedtaget af EUs Ministerråd som et forlæg for udviklingen af de NQFs (National Qualifications Frameworks), som ifølge programmet skulle vedtages i 2010 (European Communities 2008).

De undersøgte dokumenter er dels blevet udleveret og/eller anbefalet af de interviewede repræsentanter for uddannelsesområdet i de fem lande, dels fundet gennem søgninger på internettet og udvalgte databaser. I relation til sidstnævnte, har forfatterne bag rapporten fået bistand fra Danmarks Pædagogiske Bibliotek ved Aarhus Universitet. Med hensyn til Island og Finland har undersøgelsen af praktiske årsager overvejende været begrænset til dokumenter, der forelå på engelsk eller svensk. 
Udover primær-kilder, bygger undersøgelsen også på tidligere undersøgelser vedrørende livslang læring og voksenuddannelse i de nordiske lande.

\subsubsection{Interview}

Der er gennemført interview med 8-9 personer (embedsmænd og interessenter) i hvert af de fem lande. Fokus for interviewene har været det samme som for litteraturstudiet/dokumentanalysen. Interviewer har i forbindelse med interviewene sammenlagt tilbragt op til tre dage i hvert land ${ }^{1}$. De interviewede er udvalgt på baggrund af anbefalinger fra de nationale repræsentanter i Styregruppen for Voksnes Læring under Nordisk Ministerråd (SVL).

Som supplement til interviewene er der udarbejdet et spørgeskema, der efterfølgende er blevet sendt til de interviewede. Dette spørgeskema er blevet besvaret af embedsmænd og indgår som baggrundsmateriale til undersøgelsen.

\subsection{Begrebsafklaring}

Denne undersøgelses overordnede formål er jævnfør ovenstående at analysere, hvorledes de nordiske lande søger at fremme livslang læring, altså landenes strategier for livslang læring.

Strategier forstås i den forbindelse dels som konkrete nedskrevne strategier, udarbejdet af de respektive regeringer og ministerier, dels - hvor der ikke findes nedskrevne strategier - kommissorier og andet skriftligt arbejde, der angiver landenes retning inden for området. Strategierne består således både af offentligt skriftligt materiale, af skriftligt materiale, der er udleveret i forbindelse med interview med embedsværket og interessenter, samt af tendenser der har kunnet udledes af interviewene.

Begrebet livslang læring dækker som udgangspunkt over læring „fra vugge til grav." Ofte anvendes begrebet dog som bred betegnelse for vok-

\footnotetext{
1 Interviewene blev foretaget den 12. april, den 12. maj 2010 i København, den 17. maj 2010 i Aarhus, den 26.-27. april 2010 i Helsinki, den 7.-8. april 2010 i Reykjavik, den 19.-20. april og den 4.-5. maj 2010 i Oslo og den 13.-15. april 2010 i Stockholm.
} 
sen- og efteruddannelse. Det er den sidste forståelse, der ligger til grund for nærværende undersøgelse, der således omfatter livslang læring for voksne, forstået som folkeoplysning, almen voksen- og efteruddannelse og erhvervsrettet voksen- og efteruddannelse. Uddannelsessystemerne er bygget meget forskelligt op i de nordiske lande, ikke mindst voksen- og efteruddannelsessystemerne. I bilagene 1-5 er uddannelsessystemerne for hvert af de nordiske lande illustreret, således at det er muligt at få et overblik over det enkelte lands system.

\subsubsection{Livslang læring vs. voksnes læring}

I de nordiske lande forstås „livslang læring for alle“ som et overordnet politisk princip, og sådan har det været siden februar 1995, hvor Nordisk Ministerråd offentliggjorde rapporten „Guldtavlerne i græsset. Livslang læring for alle". Denne rapport blev udarbejdet af en nordisk tænketank, der i december 1992 var blevet nedsat på en konference i Gøteborg arrangeret af Styringsgruppen for nordisk folkeoplysning og voksenundervisning (FOVU). Allerede i 1988 beskæftigede Nordisk Ministerråd sig med livslang læring og begrebet spillede en central rolle i rådets handlingsplan for det kulturpolitiske samarbejde (Nordisk Ministerråd 1988).

Efter 2000 tager EU begrebet til sig med vedtagelsen af Lissabonstrategien. Det sker i en periode, hvor Danmark, Finland og Sverige er blevet medlemslande, mens Island og Norge fortsætter som associerede lande. Efter vedtagelsen af Lissabonstrategien tager EU begrebet til sig, og Kommissionen gennemfører 2000-2001 en omfattende høring hos medlemslandene (herunder Danmark, Finland og Sverige) og de associerede lande (blandt andet Island og Norge). Det bliver især bidragene fra de nordiske lande, der får indflydelse på EUs beslutning om at gøre sigtet bredt. Livslang læring det nye fælles EU-begreb - skulle bidrage til økonomisk vækst, øget beskæftigelse, bedre miljø, social integration m.v. (European Commission 2001). Det konkrete arbejde med implementeringen blev forankret i arbejdsprogrammet „Education and Training 2010“ (Pepin 2007), og EUs Ministerråd opfordrede i 2004 landene til at udarbejde og beslutte nationale strategier for livslang læring. Mht. voksnes læring blev der taget særskilte initiativer: Kommissionen udsendte i 2006 en særlig meddelelse, der bar navnet „Det er aldrig for sent at lære" (Kommissionen for de europæiske fællesskaber 2006), og året efter kom handlingsplanen „Der er altid et godt tidspunkt at lære“ (Kommissionen for de europæiske fællesskaber 2007). Andre vigtige 
initiativer har været European Qualifications Framework (EQF), der startede i 2004, og som lagde op til vedtagelsen af nationale kvalifikationsrammer i 2010, samt Ministerrådets rekommandation af Kommissionens beskrivelse af otte „nøglekompetencer“ (2006). I Kommissionens program for udviklingen 2007-2013 blev alle former for uddannelse og træning betegnet som „livslang læring“ (EU-tidende 2006).

Siden 1984, hvor Nordisk Ministerråd nedsatte FOVUs første styringsgruppe, havde "folkeoplysning og voksenundervisning" været et fællesnordisk policy-begreb. Efter tyve år blev styringsgruppen reorganiseret og skiftede navn til Styringsgruppen for voksnes læring (SVL). Navneskiftet ses som en konsekvens af, at alle nordiske lande anerkendte „læring“ som relevant for området.

SVLs projekter og rapporter har „Voksnes læring“ som nøglebegreb, og der er således overensstemmelse i forhold til OECD, der anvender begrebet „adult learning“ i projekter og rapporter. Når det er relevant at kortlægge sprogbrugen, skyldes det, at en kortlægning kan bidrage til at afklare, hvornår de nordiske lande opgav undervisningsbegrebet til fordel for læringsbegrebet. En del forskere kalder denne ændring et paradigmeskift (Tuijnman, 1992).

UNESCO vedtog i 1965 en definition af „lifelong education“, som vurderes at have fungeret som fundament for policy-formuleringen i de nordiske lande:
„...the animating principle of the whole process of education regarded as continuing through an individual's life from his earliest childhood to the end of his days and therefore calling for integrated organization. The nec- essary integration should be achieved both vertically, through the duration of life, and horizontally to cover all the various aspects of the life of indi- viduals and societies..." (Ehlers, 2009).

Siden UNESCOs oprettelse havde de nordiske lande sendt delegationer til de verdenskonferencer om „adult education“, der blev gennemført i Helsingør (1949), i Montreal (1960) og i Tokyo (1972), og de havde spillet en aktiv rolle, når konferencerne blev forberedt. Efter Tokyo-konferencen udsendte UNESCO betænkningen „Learning to be. The world of education today and tomorrow" (Faure m.fl. 1972), der beskrev resultaterne af et verdensomfattende udvalgsarbejde. Den sidste del af teksten fremlægger under overskriften „Towards the learning society“ 21 sammenhængende anbefalinger, der henvender sig til regeringerne i UNESCOs medlemslan- 
de. Den første anbefaling bygger på et princip om at „every individual must be in a position to keep learning throughout his life. The idea of lifelong education is the keystone of the learning society."

I 1970erne kom disse udmeldinger til at øve indflydelse på de nordiske landes arbejde med at udvikle en selvstændig politik for området. Det kan nævnes, at i Finland og Norge tog regeringerne udgangspunkt i UNESCOs definition, og at Stortinget i Norge vedtog en lov om „voksenopplæring“ (Kunnskapsdepartementet, 1976). i Danmark besluttede UNESCOs Nationalkommission sig for at oversætte begrebet som „livslang integreret uddannelse/udvikling“, men denne konstruktion fik ingen gang på jorden. K. Grue-Sørensen, der var professor i pædagogik ved Københavns Universitet, stillede sig afvisende overfor hele tankegangen, og i hans „Almen pædagogik. En håndbog i de pædagogiske grundbegreber" (1974) forsøgte han sig med begrebet „læren.“

I Sverige reagerede professor Torsten Husen fra Stockholms Universitet modsat. I „The Learning Society“ (1974), der udkom i flere oplag, argumenterede han for en implementering af princippet. I Norge anvendte man fra starten begrebet „læring“, og det faldt i god jord. Vi kan finde begrebet i en række norske udredninger som f.eks. „Livslang læring“ (Norges offentlige utredninger, 1986).

I 1980erne havde „det lærende samfund“ stadig en utopisk klang, og først i 1990erne begyndte de nordiske lande at gå ind i diskussionen. Samtidig var man i England begyndt at anvende begreber som „competence development" (Burke, 1989) og „learning outcomes“ (Jessup, 1991).

OECD havde siden 1973 benyttet begrebet "recurrent education“, der oprindelig stammede fra Sverige, hvor det hed „återkommande utbildning“, og argumenterede fra 1996 for „lifelong learning for all.“ EU udsendte rapporten „Teaching and learning - Towards the learning society“ (EU 1995) og gennemførte en omfattende kampagne, der blev kaldt „Year of Lifelong Learning“ i 1996. Også UNESCO stillede om til livslang læring, da der blev holdt i verdenskonference i Hamborg i 1997.

Man kan diskutere, om der i realpolitisk forstand er en forbindelseslinje mellem de policy-begreber, der blev diskuteret i 1970erne og dem, der kom på den politiske dagsorden i slutningen af 1990erne, men der synes at være enighed om, at de nordiske lande kom først med en udmelding af princippet om „livslang læring for alle.“ 


\section{Den kompetencepolitiske indsats siden 2000}

Efter anden verdenskrig kom de nordiske lande ind i et tæet samarbejde. Nordisk Råd bidrog væsentligt til en harmonisering af lovgivningen i landene, og denne proces kulminerede i 1968-71 med forhandlingerne om en nordisk økonomisk union (NORDEK). Imidlertid endte forhandlingerne uden et resultat, således at et enkelt nordisk land (Danmark) tilsluttede sig det europæiske fællesskab (EF). Dette medførte, at det nordiske samarbejde blev intensiveret gennem Nordisk Ministerråd, der oprettedes i 1971 som et fælles samarbejdsorgan. En omfattende aftale om kulturelt samarbejde mellem de nordiske lande indebar, at samarbejdet inden for forsknings- og uddannelsespolitikken blev permanent (Wendt 1979).

\subsection{Danmark}

I Danmark har kompetencepolitikkens mål været identiske med målene for Lissabonstrategien, der blev vedtaget af EUs Ministerråd i 2000. Herefter blev kompetenceudvikling anset for at være det værktøj, der kunne sikre konkurrrenceevnen og beskæftigelsen. Der blev især satset på kompetenceudvikling, der var formaliseret og erhvervsrettet.

I 2002 præsenterede regeringen en handlingsplan for udviklingen af de danske uddannelser, „Bedre uddannelser“ (Undervisningsministeriet 2002). Planen var resultatet af et samarbejde mellem Undervisningsministeriet, Ministeriet for Videnskab, Teknologi og Udvikling, Kulturministeriet, Økonomi- og Erhvervsministeriet, Ministeriet for Flygtninge, Indvandrere og Integration, Indenrigs- og Sundhedsministeriet, samt Beskæftigelsesministeriet. Det brede samarbejde bag rapporten understreger det brede felt, hvor uddannelse antages at spille en rolle. Planen, der var tæt forbundet med regeringens plan for vækst i Danmark - „Vækst med vilje“ - fra samme år, omhandlede blandt andet voksen- og efteruddannelse. I den forbindelse var fokus på uddannelser, der kvalificerer til videreud- 
dannelse eller til beskæftigelse, mens folkeoplysningen og den personlige udvikling, der ikke nødvendigvis kvalificerer til en uddannelse eller et job, ikke var nævnt. Af hensyn til voksnes muligheder for at deltage i uddannelse, blev der i planen blandt andet lagt vægt på at fremme en fleksibel tilrettelæggelse af uddannelserne (Undervisningsministeriet 2002). Planen førte blandt andet til en revision af loven om åben uddannelse (erhvervsrettet voksen- og efteruddannelse).

„Vækst med vilje“ blev i 2003 fulgt op med strategien „Viden i vækst“, der endnu en gang, med henvisning til blandt andet handlingsplanen „Bedre uddannelser", fremhævede behovet for en styrkelse af de erhvervsrettede voksen- og efteruddannelser (Ministeriet for Videnskab, Teknologi og Udvikling 2003).

I 2005 nedsatte regeringen Globaliseringsrådet, der fik til opgave at rådgive ministeriet om, hvordan Danmark kunne blive rustet til at klare sig i en global økonomi og blive et førende viden-, vækst- og iværksættersamfund. Resultatet af rådets arbejde blev globaliseringsstrategien, der blev offentliggjort i 2006 (Regeringen 2006). Blandt rapportens anbefalinger var, at „flere skal have lyst til og mulighed for at uddanne sig gennem hele livet" (Regeringen 2006, s. 8). For at nå dette mål lagde regeringen i strategien vægt på, at udbuddet af uddannelse skulle være målrettet og attraktivt især for personer med svage eller snævre kompetencer. Desuden skulle der indføres særlige opsparingsordninger til voksen- og efteruddannelse.

Samme år som Globaliseringsrådet udgav sin rapport, kom også en rapport fra „Trepartsudvalget for livslang opkvalificering og uddannelse for alle på arbejdsmarkedet." Trepartsudvalget var blevet nedsat af regeringen i 2004 med den opgave at kortlægge og analysere den eksisterende voksen- og efteruddannelsesindsats i Danmark og på den baggrund komme med anbefalinger til, hvordan målsætningen om livslang opkvalificering og uddannelse for alle kunne realiseres i et samspil mellem arbejdsgiverne, lønmodtagerne og det offentlige (Finansministeriet 2006). Som det indirekte fremgår af navnet på udvalget, lå fokus i rapporten på den erhvervsrettede voksenuddannelse. Det blev desuden fremhævet, at voksen- og efteruddannelse ikke alene havde sammenhæng med den grundlæggende uddannelsespolitik, men også med beskæftigelsespolitikken, social- og integrationspolitikken samt erhvervspolitikken. I lighed med Lissabonstrategien, skulle den danske voksenuddannelsespolitik således være med til at sikre økonomien, beskæftigelsen og den sociale sammenhængskraft. Blandt rapportens anbefalinger var en styrket efterspørgsel 
efter voksen- og efteruddannelse, blandt andet gennem systematisk kompetenceudvikling for beskæftigede og en bedre vejledning til såvel de beskæftigede som virksomhederne. Desuden skulle udbuddet målrettes behovet for voksen- og efteruddannelse, med særligt henblik på at styrke indsatsen over for personer med læse-, skrive- og/eller regneproblemer. Endelig foreslog udvalget en række ændringer i forhold til finansieringen af voksenuddannelse, blandt andet i form af øget deltagerbetaling på områder, der ikke kunne betegnes som kernefag, samt opsparingsordninger.

Den sidste strategi, der skal omtales her, er „Danmarks strategi for livslang læring“ fra 2007 (Undervisningsministeriet, 2007). Strategien, der var en redegørelse til EU for danske initiativer i relation til Lissabonstrategien, byggede i høj grad på rapporterne fra Globaliseringsrådet og Trepartsudvalget året før, samt en politisk aftale om oprettelse af en særlig globaliseringsfond, der var en del af implementeringen af globaliseringsrådets anbefalinger. Det nærmere indhold i strategien omtales nærmere i afsnit 3.2.1.

\subsection{Finland $^{2}$}

Den finske kompetencepolitik indgår i de fem-årige udviklingsplaner, som udarbejdes af ministerielle embedsmænd. Femårsplanerne skal godkendes af regeringen, der også godkender Social- og Sundhedsministeriets planer for udvikling af førskoleområdet og Beskæftigelses- og Økonomiministeriets planer for AMU-området.

Finland gik uden betænkning ind i den transnationale samordning, der byggede på EUs arbejdsprogram „Education and Training 2010“ (Commission of the European Communities 2003). Forfatterne bag den finske statusrapport for arbejdet i relation til planen i 2007, fremhæver dog også, at det efter deres vurdering ikke var nødvendigt at udarbejde en særlig strategi til brug for EU, der lå ud over det arbejde, der allerede blev gjort i Finland (Ministry of Education 2007).

I lighed med situationen i Danmark, er der også i Finland en tendens til at fokusere på erhvervsrettet voksenuddannelse. De folkeoplysende insti-

${ }^{2}$ Afsnit 2.2 om Finland bygger primært på Undervisnings- og Kulturministeriet 2008. 
tutioner i Finland organiserer således erhvervsrettet uddannelse på lige fod med erhvervsskolerne, fordi produktivitet og økonomisk vækst betragtes som et fælles mål for hele uddannelsesområdet. Den finske styring af området er i en sammenligning med de øvrige nordiske lande præget af, at voksenuddannelse forstås som et marked (Tuomisto, 1998). Finland bygger i dag på en efterspørgselsmodel, idet man har bevæget sig væk fra en udbudsmodel, hvor uddannelsesinstitutionerne sælger standardiserede kurser som „hyldevarer." Den effektive omstilling til en efterspørgselsmodel anerkendes af OECD i publikationen „Thematic Review on Adult Learning. Finland“ (OECD 2001b).

I 2001 anmodede Parlamentet regeringen om at nedsætte en komité, der kunne formulere en ny politik for området, herunder nye modeller for financiering. Komiteen udgav sin betænkning året efter. For det første blev det foreslået, at basisresourcerne for voksenuddannelse i den følgende tiårsperiode i højere grad end tidligere blev rettet mod erhverv, efteruddannelse og voksenuddannelse på universiteter og erhvervshøjskoler i overensstemmelse med udviklingen i befolkningens aldersstruktur og uddannelsesniveau, samt ændringerne i erhvervsstrukturen. Målet var, at alle borgere havde mulighed for at deltage i en-to ugers uddannelse hvert år, og med 10 til 15 års mellemrum havde mulighed for en mere grundlæggende revidering af deres kundskaber. Det frivillige uddannelsesarbejde skulle også spille en central rolle i voksenuddannelsen. For det andet foreslog gruppen, at den aktive voksenbefolkning som mangler eksamen på niveau 2 ifølge den nationale kvalifikationsramme (NQF), tilbydes mulighed for at skaffe sig en sådan eksamen gennem et separat „opretnings“ program (åtgärdsprogram). Programmet gennemføres som et femårigt projekt for et årligt antal på mellem 8.000 og 12.000 årsstudiepladser. Udover at øge volumen fokuseres der på målgruppens motivation og på den såkaldte opsøgende virksomhed. Sidstnævnte blev betegnet det finske „Kunskapslyftet“ eller „Lyftet" og kørte fra 2003-2009. For det tredje blev der etableret et samarbejde mellem voksenuddannelsesinstitutionerne i hver region mellem forvaltninger og virksomheder, med henblik på at møde den voksne befolknings behov. Formålet var dels at erhvervsuddannelsesudbudet skulle blive mere mangfoldigt, dels at styrke aktørerne inden for uddannelse for arbejdslivet og den regionale udvikling.

Efter rigsdagsvalget i 2007 og det følgende regeringsskifte, påbegyndte den nye regering en "totalreform" af den erhvervsmæssige voksenuddannelse (AKKU-projektet). Med erhvervsmæssig voksenuddannelse forstod 
man erhvervsuddannelse for voksne, lærlingeaftale, beskæftigelsesuddannelse for arbejdsløse eller folk som er truet af arbejdsløshed, personaleuddannelse af lønmodtagere samt universitetsuddannelse for voksne. Reformen blev annonceret i Undervisningsministeriets udviklingsplan for 2007-2012 (Mäenpää 2007). Modellen for voksnes erhvervsuddannelse påkalder sig opmærksomhed, fordi den inkluderer aktivitetsformer, der almindeligvis anskues hver for sig: Erhvervsmæssig efteruddannelse (formel), lærlingeuddannelse (formel og non-formel) og virksomhedsinterne kurser (non-formel). To principper er grundlæggende: Efterspørgselsstyring og offentlige-private partnerskaber. I et nordisk perspektiv er det den konsekvente individualisering og arbejdspladslæringen (en variant af en lærlingemodel), der er fornyende. Det synes at være virksomhederne - ikke uddannelsesinstitutionerne - der sætter dagsordenen, og dette er muligt pga. en fleksibilitet, der sikres gennem de 174 „eksamenskommissioner" (Friberg og Modig 2010), der til sammen dækker hele landet og alle brancher. Det er kommissionerne, der varetager de „fritstående" deleksaminer for voksne, der udgør den finske form for realkompetencevurdering.

Omfattende fusioner indgår i Finlands langtidsplanlægning: På det videregående niveau for erhvervsuddannelse (yrkeshögskolorna) har Finland p.t. 26 institutioner, og regeringen ønsker at reducere antallet til 18, idet målet er, at hver af disse institutioner skal have ca. 2.500 heltidsstuderende (Friberg \& Modig, 2010). Regeringen ønsker altså at forøge den „kritiske masse“ på den enkelte institution. Undervisningsministeriets udviklingsplan omfatter endvidere en reform af det „fria bildningsarbetet", hvor der lægges op til nye finansieringsformer, strukturelle ændringer, kvalitetssikring og forskningsforankring.

I forbindelse med en fusion af to ministerier, oprettedes i 2008 et Beskæftigelses- og Økonomiministerium. Ministeriet opstillede i juni 2010 fire strategiske mål (Interview med det finske embedsværk 26.-27. april 2010):

- At gøre virksomhederne i stand til at vokse

- At forøge iværksætteraktiviteten

- At gøre det nemmere at finde et job i en fart

- At støtte voksne med særlige problemer

Et af midlerne til at nå disse mål er voksnes læring. 


\subsection{Island $^{3}$}

Island har foretaget en gennemgribende revision af lovgivningen på førskoleområdet, på grundskoleområdet, på ungdomsuddannelsesområdet og på universitetsområdet, og dette er sket i overensstemmelse med den politiske proces, der gik i gang, da EU i 2000 vedtog Lissabonstrategien. På disse områder afviger de islandske modeller ikke væsentligt fra dem, der anvendes i de øvrige nordiske lande.

Island har efterlevet de fleste af de retningslinier, der er blevet lagt $\mathrm{i}$ forbindelse med arbejdsprogrammet „Education and Training 2010“, men har ikke formuleret en strategi for livslang læring efter EUs retningslinier, selvom landet allerede i 1995 tilsluttede sig princippet om „lifelong learning for all" (Nordic Council of Ministers 1995). Arbejdet med at udvikle en islandsk kvalifikationsramme er ved at være afsluttet, og det islandske undervisningsministerium har søgt EU om midler til at iværksætte en national oplysningskampagne.

Når det gælder arbejdet med kortuddannede voksne, anvender Island sin egen model. Siden 2003 har arbejdsmarkedets parter haft deres egen institution (FA), der koordinerer udbuddet af uddannelsestilbud til voksne. FA er en ikke-offentlig aktør, der har skrevet kontrakt med det islandske undervisningsministerium og derfor optræder som det organ, der i praksis sørger for forvaltningen af en decentral model med ti udbydere, der har specialiseret sig i uddannelse af kortuddannede. Udbyderne er „Mimir-simenntun“ i Reykjavik, ejet af LO, og ni uddannelsescentre på landet, som drives og ejes af en kreds af lokale interessenter. Disse interessenter er typisk arbejdsmarkedets parter, kommunen, foreninger og offentlige uddannelsesinstitutioner i lokalområdet. Denne landsdækkende „infrastruktur“ for uddannelse af kortuddannede, der også omfatter „minicentre" på mange af uddannelsescentrene, er opbygget inden for en halv snes år, og den har FA som sin centrale serviceorganisation.

FA forvalter de mange millioner, som staten efter trepartforhandlinger afsatte til arbejdet med kortuddannede. Den beslutningsproces, der gik forud for etableringen af den islandske model, ligner forløbet i Norge.

\footnotetext{
${ }^{3}$ Afsnit 2.3 om Island bygger primært på interviews med embedsmænd og interessenter, der var involveret i udviklingen af området. Interviewene blev gennemført i Reykjavik den 7.-8. april 2010.
} 
Således afsatte staten i 1997 efter langvarige forhandlinger med arbejdsmarkedets parter midler til uddannelse af voksne. Implementeringen afviger dog fra den norske: Den islandske stat overlod forvaltningen af de statslige midler til en ikke-offentlig aktør. Da Islands andel af deltagere i voksenuddannelse ifølge OECD (2008) ligger på det samme høje niveau som i de øvrige nordiske lande, må modellen siges at være effektiv.

Også når det gælder vejledning af kortuddannede synes Island at have udviklet en effektiv model. Alle ti uddannelsescentre samt to efteruddannelsescentre har ansat deres egne vejledere, og disse ca. 20 ikke-offentlige vejledere har en professionel baggrund, idet de er uddannet på Islands Universitet. Denne stærke bemanding kan bidrage til at forklare, hvorfor den islandske model for realkompetencevurdering har haft succes. Omkring 500 voksne har været igennem en vurdering, der er blevet gennemført af medarbejdere fra erhvervsskoleområdet. Det islandske undervisningsministerium holdt allerede i 2003 en national konference om temaet og FA deltog i et af EUs første udviklingsprojekter inden for området. Derefter indgik FA en overenskomst med ministeriet og fik til opgave at udvikle området. En vejledning blev trykt i 2006, og de første realkompetencevurderinger blev gennemført i 2007 af efteruddannelsescentrene i industrisektoren, som er ejet af arbejdsmarkedets parter

De kortuddannede, der har fået deres realkompetencer vurderet, synes at have haft en meget positiv oplevelse. Dette er resultatet af en interviewundersøgelse, der blev gennemført af en specialestuderende på Islands Universitet. FA laver introduktionsforløb for de fagpersoner, der skal gennemføre vurderingerne, og det er efter de første forløb lykkedes FA at få nedbragt gennemløbstiden. FA kan i dag beregne præcist, hvor mange penge der kan spares, hvis kortuddannede gennemfører en realkompetencevurdering, inden de går i gang med en formel erhvervsuddannelse. Disse beregninger gælder kun formel erhvervsuddannelse. FA har ikke gjort erfaringer med formel almenuddannelse.

Et andet eksempel på en succesrig islandsk model er en medarbejderuddannelse, der fra 2005 blev udviklet af ITIA, turistbranchens arbejdsgiverorganisation, SGS, største specialarbejderforbund i Island og FA. Turisme er efter finanskrisen blevet et satsningsområde i Island, og denne uddannelse for kortuddannede, der udspringer af et Leonardo-projekt, var klar allerede i 2007 og gennemføres i et samarbejde mellem turistbranchen og de ti uddannelsescentre for kortuddannede. Der er adskillige an- 
dre islandske eksempler på, at arbejdsmarkedets parter tager ansvar, når der opstår nye behov for uddannelse af voksne.

FA og de tolv udbydere har hidtil udelukkende arbejdet med voksne, der er medlem af det islandske LO (ASI), men den voksenuddannelseslov, som Altinget besluttede sig endeligt for i marts 2010 (Althingi, 2010), kommer til at gælde for alle kortuddannede i Island. Loven formaliserer en partnerskabsmodel, der allerede er udviklet. Staten vil stadig ikke styre forvaltningen af de offentlige midler, men overlader det til en bestyrelse på ni medlemmer. Formanden udpeges af ministeren, mens ASI (LO) og SA (arbejdsgiverne) kan besætte fire af pladserne. De sidste fire pladser gives til repræsentanter for de offentligt ansatte, kommunerne, Finansministeriet og Socialministeriet. Lovgivningen gør det muligt at fortsætte med en partnerskabsmodel, der bygger på en central ikke-offentlig forvaltning, der forvalter offentlige midler, organiserer kvalitetsudvikling, akkreditering m.v.

\subsection{Norge}

EUs beslutning om at udvikle medlemslandene til „vidensøkonomier" fik betydning for Norge. Omstillingen fra en tænkning i uddannelsespolitik til en tænkning i kompetencepolitik var imidlertid påbegyndt allerede, da Gudmund Hernes var undervisningsminister (1990-95). Det er karakteristisk for den langsigtede tænkning i livslang læring, at regeringen nu indgik to aftaler med OECD: Dels om levering af et „Thematic Review on Adult Learning" i lighed med dem, som OECD leverede til Danmark, Finland og Sverige, dels om et bredere review om "Lifelong Learning in Norway“ (OECD 2002).

Norge indgår i et større komparativt projekt om implementeringen af livslang læring, som forskere i 13 lande gennemfører under EUs 6. rammeprogram for forskning. Det vurderes i rapporten om Norge (Ure 2007), at dette nordiske land påvirkes afgørende af to drivkræfter, der bidrager til udvikling af livslang læring: 
- En stærk og vedholdende statslig styring og et tæt samspil med organisationer som UNESCO, OECD og EU. Ure anser dog ikke arbejdsmarkedets parter for at være væsentlige drivkræfter og anfører, at parternes engagement i Kompetansereformen var kortvarigt. F. eks. blev parternes fælles sekretariat hurtigt nedlagt, og det samme gjaldt det forum for national koordination, der var blevet nedsat af regeringen. Trepartssamarbejdet er imidlertid stadig aktuelt for området

- De internationale organisationer, der kontinuerligt påvirker landet gennem sammenligninger og policy papers. Desuden nævner forfatteren det nordiske samarbejde (Ure 2007)

Det kan i det samlede billede være interessant at notere sig, at studieforbundene og deres medlemsorganisationer fortsat har et deltagerantal i nærheden af en halv million. Folkehøjskolerne har større søgning end nogensinde før og spiller en vigtig rolle i kompetenceudviklingen af unge. Begge disse bidragydere i den tredje sektor har aktivt medborgerskab og demokratisering som hovedmålsætning i deres nationale og internationale virksomhed.

Den norske stats indsats for at reformere parallelt med udviklingen inden for „Education and Training 2010“ fremgår bl.a. af de aktiviteter, der administreres af Vox - det "nasjonale fagorgan for kompetansepolitikk“ der i 2001 blev dannet af tre statslige institutioner: Statens ressurs- og voksenopplæringssenter (SRV), Norsk fjernundervisning (NFU) og NVI. Vox fik det administrative ansvar for de 740 udviklingsprojekter i KUPprogrammet, som staten finansierede mellem 1999 og 2006, og det var også Vox, der gennemførte udviklingen af Realkompetanseprojektet (1999- 2003). Nyere initiativer under Vox drejer sig om den nationale koordinering af vejledning af voksne (Karriereveiledningsentrene) og administrationen af statstilskud til læring på arbejdspladsen (BKA), samt grundlæggende færdigheder i læsning, regning og IKT. Vox er endvidere forvaltningsorgan for statsstøtte til studieforbundene.

Siden 1960erne har norske ministerier produceret en række rapporter til Stortinget, der direkte eller indirekte bidrog til udviklingen af policies vedrørende livslang læring for alle, og de skiftende regeringer synes generelt at have haft en heldig hånd med at koordinere den nationale indsats (Ure 2007). Den seneste rapport til Stortinget diskuterer behovet for en styrket koordination (Kunnskapsdepartementet 2009a). 
Et karakteristisk eksempel på Norges vilje til international koordination er en rapport, som departementet udarbejdede i 2006 (Kunnskapsdepartementet 2007b). Baggrunden for rapporten var, at samarbejdet inden for arbejdsprogrammet „Education and Training 2010“ indebar, at EUs medlemslande og associerede lande skulle udarbejde nationale strategier for arbejdet med implementeringen af livslang læring. Departementet besluttede at udarbejde en omfattende „tilstandsrapport" på 40 sider og at offentliggøre den i en norsk og i en engelsksproget udgave.

\subsection{Sverige}

I maj 2001 antas regeringens proposition „Vuxnas lärande och utvecklingen av vuxenutbildningen“ (prop. 2000/01:72) och där den omstrukturering av vuxenutbildningen som initierades genom Kunskapslyftet permanentas. Den enskilde individens behov av utbildning skall vara styrande, inte en utbildningsorganisations utbud. Anställningsbarhet lyfts fram som ett central begrepp i utbildningssammanhang, en policy som inte enbart berör vuxenutbildningen (Fejes 2006). I propositionen om „Den öppna högskolan“, med underrubriken: „Från vaggan till graven“ (prop. 2001/02:15) sätts individens egna utbildningsönskningar och intressen i centrum, samtidigt som arbetsmarknadens och näringslivets behov av kompetens betonas. Högskolan, liksom vuxenutbildningen, ska nu växla över från att ha varit utbudsstyrd till att vara behovsstyrd. Förnyelse av innehåll, arbetsformer och distributionsformer blir därmed av central betydelse. Under 1960- och 70-talen företräds begreppet livslångt lärande av humanistiska värderingar, medan de ekonomiska värderingarna träder i förgrunden under 1990-talet. Att begreppet fick ett så begränsat genomslag under 1960- och 70-talen beror delvis på att begreppet var grundat i en ekonomi med full sysselsättning, till skillnad från det allt mer kärva ekonomiska klimatet som inträdde under 1990-talet.

Den omstruktureringen av vuxenutbildningen som initieras under 1990-talet inbegriper bland annat införandet av ett mål- och resultatorienterat styrsystem, en ekonomisk fördelningsprincip där kommunen själv ska förmedla medlen mellan olika sektorer, införandet av en marknadsorientering med lokala (kommunala) upphandlingsprocedurer och där privata utbildningsaktörer kan konkurrera med kommunens. Det lokala ansvaret för att reglera utbildningsverksamheten görs starkare. Känne- 
tecknande för vuxenutbildningens strukturella förändring är också en växande statlig kontrollapparat. Måldokument, planer och utvärderingar skall utarbetas och rapporteras såväl inom den enskilda kommunen som till staten. (Lumsden Wass, 2004). Undervisningsformerna styrs genom upphandlingsavtalen, från att i huvudsak ha inneburit gruppundervisning, till mer it-baserade former och individuell handledning. Man kan här konstatera att bland anordnare av formell behörighetsgivande vuxenutbildning återfinns både folkhögskolor och studieförbund. Folkbildningen finns samtidigt kvar, med sina statsunderstödda utbildningar av icke-formell karaktär, där medlen fördelas av Folkbildningsrådet.

Även arbetsmarknadsutbildningen har reformerats och upphandlas numera i konkurrens mellan utbildningsanordnare. Den är dock fortfarande inte en del av det formella utbildningssystemet. År 1999 infördes målet att 70 procent av deltagarna skall ha fått arbete inom tre månader efter avslutad utbildning. Likaså upphörde under 2001 möjligheten att använda utbildning som ett medel för att kvalificera sig till en ny ersättningsperiod inom arbetslöshetskassan. Det är rimligt att anta att detta sammantaget har påverkat urvalet av deltagare.

Här kan också nämnas nya satsningar som initierats av regeringen under 2000-talets senare del med betoning på yrkesutbildning för vuxna. Yrkesvux är en i tid avgränsad satsning på yrkesinriktad gymnasial vuxenutbildning som genomförs mellan åren 2009 och 2011 med syftet att motverka brist på yrkesutbildad arbetskraft (prop. 2009/10:1). Från och med hösten 2011 erbjuds landets kommuner möjlighet att ansöka om statsbidrag för anordnande av lärlingsutbilning för vuxna inom kommunal vuxenutbildning på gymnasial nivå och inom gymnasial vuxenutbildning för utvecklingsstörda (SFS 2010:2016). Detta initiativ ska genomföras mellan åren 2012 och 2014. En ny och mer långsiktig utbildningsform, Yrkeshögskolan, startade hösten 2009. Avsikten är att Yrkeshögskolans utbildningar ska anpassas efter branchers och arbetsmarknadens varierande behov. En ny myndighet med ansvar för frågor som rör yrkeshögskolan har etablerats, nämligen Myndigheten för yrkeshögskolan. Yrkeshögskoleutbildningarna ska ersätta utbildningsformen Kvalificerad utbildning (Kyutbildningar) som funnits i ca 15 år (www.yhmyndigheten.se). 



\section{Udviklingen af nationale strategier}

\subsection{Samarbejdet mellem myndigheder og arbejdsmarkedets parter}

På trods af forskelle i strukturen på arbejdsmarkedet, synes det at være et fællestræk ved de nordiske lande, at der er et tæt samarbejde mellem de offentlige myndigheder og arbejdsmarkedets parter, når det gælder formuleringen og implementeringen af politik af betydning for arbejdsmarkedet. Styringen af arbejdsmarkedsforhold samt økonomi- og socialpolitik har således bygget på forhandlinger mellem de tre parter: de offentlige institutioner, arbejdsgiverne og arbejdstagerne (Dølvik 2007; Mailand 2009).

Samarbejdet mellem myndigheder og interesseorganisationer, herunder arbejdsmarkedets parter, i de nordiske lande er således præget af korporative træk. Pekkarinen (1992) fremhæver i den forbindelse en høj organisationsgrad, centraliserede lønforhandlinger og organisationernes inddragelse i politikformuleringen som korporative træk, der går igen i de tre nordiske lande, som han har undersøgt: Norge, Sverige og Finland. Mailand konkluderer ligeledes i et studie fra 2009, at der er stærke korporative træk i både Danmark og Norge, men også at der er stor forskel mht. de måder, hvorpå arbejdsmarkedets parter interagerer med embedsværket.

Også Pekkarinen er inde på, at der er forskel på den konkrete udformning af organisationernes inddragelse, ligesom der er forskelle i den historiske fremvækst af de korporative træk. Mens de korporative træk i Norge og Sverige går tilbage til længe før krisen i 1970erne, er de korporative træk i Finland ifølge Pekkarinen blevet styrket efter krisen i 1970erne (Pekkarinen 1992). Fra 1968 fandt lønmodtagerorganisationerne, hvor de organiserede kommunister hidtil havde spillet en væsentlig rolle, sammen med staten og arbejdsgiverne i trepartsforhandlinger (Elvander 2002). Traditionen for at inddrage organisationerne i politikforberedelsen i Norge går ifølge Nordby tilbage til etableringen af de første udvalg i slutningen af 1800-tallet, men fik først egentlig betydning fra midten af 
1960erne, hvor antallet af udvalg steg kraftigt. I den norske magtudredning fremhæves således betydningen af organisationernes deltagelse i statslige udvalg som et permanent indslag i norsk politik i forbindelse med formuleringen af politikken (Nordby 1999). For Danmarks vedkommende har arbejdsmarkedets parter især haft indflydelse på arbejdsmarkedets forhold gennem et stærkt topartsystem, der går tilbage til parternes gensidige anerkendelse i 1899. Parterne har desuden en væsentlig indflydelse gennem deltagelse i diverse midlertidige trepartsudvalg nedsat af skiftende regeringer (Mailand, 2009).

\subsubsection{Danmark}

Organisationernes indflydelse på politikformuleringen i Danmark er tydelig i forbindelse med reformerne inden for voksenuddannelsesområdet. Arbejdsmarkedets parter deltog således sammen med andre relevante interesseorganisationer i forarbejderne til reformerne af voksenuddannelsessystemet både i 1999 og i 2006. Selv om arbejdsmarkedets parter ikke var repræsenteret i den komité, der stod bag 1999-rapporten „Mål og midler i offentligt finansieret voksen- og efteruddannelse“, blev resultaterne efterfølgende diskuteret i et trepartsforum, hvor arbejdsmarkedets parter accepterede hovedparten af reformen (Mailand, 2009).

Med hensyn til de løbende reformer af voksen- og efteruddannelsessystemet siden 2000, har arbejdsmarkedets parter været mere direkte involveret med repræsentanter i diverse udvalg (Jørgensen 2010). Da regeringen i 2005 nedsatte Globaliseringsrådet, bestod det blandt andet af repræsentanter for arbejdsmarkedets parter, samt fra uddannelses- og forskningsverdenen. Rådet havde i alt 26 medlemmer, hvoraf 10 kom fra enten en arbejdsgiver- eller en arbejdstagerorganisation. Blandt medlemmerne af rådet var desuden fem ministre, med statsministeren som formand for udvalget. Samtidig med Globaliseringsrådet nedsatte regeringen også et ministerudvalg, der skulle udarbejde en vision og strategi for at udvikle Danmark til et førende vækst-, viden- og iværksættersamfund. Globaliseringsrådets opgave var at rådgive dette ministerudvalg (Regeringen, 2006).

Også Trepartsudvalget for livslang opkvalificering og uddannelse for alle på arbejdsmarkedet havde, som det fremgår af navnet, repræsentation ikke alene fra regeringen, men også fra arbejdsmarkedets parter. Af de 24 medlemmer af udvalget var 17 fra arbejdsmarkedets parter. Derudover var Kommunernes Landsforening samt Amtsrådsforeningen og fem mini- 
sterier repræsenteret, med Finansministeriet som formand for udvalget. Trepartsudvalgets opgave var, at analysere og vurdere den eksisterende voksen- og efteruddannelse, samt komme med forslag til udvikling af området på baggrund af analyserne (Finansministeriet, 2006).

Udover deltagelsen i de diverse udvalg, har arbejdsmarkedets parter også været inddraget i processen om reformer af voksenuddannelsessystemet gennem blandt andet deltagelse i konferencer og seminarer. Da regeringen i 2007 præsenterede sin strategi for livslang læring, byggede den altså i høj grad på forarbejder præget af et samarbejde mellem staten og arbejdsmarkedets parter.

\subsubsection{Finland}

Interessegrupper inddrages også i vidt omfang i forberedelsen af uddannelsespolitikken i Finland. Det gælder ikke alene arbejdsmarkedets parter, men også de regionale og lokale myndigheder, samt repræsentanter for undervisere, elever/studerende og uddannelsesinstitutionerne (Ministry of Education, 2007). Det finske arbejdsmarked var i den første efterkrigstid præget af konstant uro. Fra 1968 fandt parterne sammen i „trepartsforhandlinger" med den finske stat, og denne model har stabiliseret forholdene $\mathrm{i}$ et sådant omfang, at arbejdsmarkedet i kriseperioder som 1970erne og 1990erne, hvor arbejdsløsheden blev meget omfattende, har været i ro. Fra 1968 og frem til i dag har arbejdsgiverorganisationer, fagforeninger og regeringen indgået indkomstpolitiske aftaler, som ofte har omfattet aftaler om lønmodtagernes uddannelsesmuligheder. Arbejdsgiverne, arbejdstagerne og staten har i de konkrete situationer været i stand til at indgå en „social pagt“ (Elvander 2002).

I det følgende omtales en række væsentlige fora for udviklingen af voksenuddannelsespolitikken og Finlands strategi for livslang læring. Fælles for de forskellige fora er en inddragelse af arbejdsmarkedets parter.

I 2001 nedsatte regeringen efter opfordring fra parlamentet en voksenuddannelseskomité, der skulle komme med forslag til voksenuddannelsespolitik og -finansiering i de kommende år. Udover de større politiske partier, samt Undervisningsministeriet og Arbejdsministeriet, var der i komitéen repræsentanter for arbejdsmarkedets parter og udbyderne af voksen- og efteruddannelse. Komitéen præsenterede, jf. kapitel 2.2, resultaterne af sit arbejde i 2002 (Ministry of Education 2008). 
Et andet væsentligt organ er Voksenuddannelsesrådet, der indtil 2009, hvor det blev afløst af Rådet for livslang læring, blev nedsat for perioder af tre år. Medlemmer af rådet var medlemmer af parlamentet, voksenuddannelseseksperter samt repræsentanter for arbejdsmarkedets parter. Rådets opgave var blandt andet at komme med forslag til udvikling af voksenuddannelsesområdet (Ministry of Education 2007; Statsrådet 2009; Ministry of Education 2008).

I 2007 nedsatte den finske regering en styregruppe, der fik til opgave at forberede en reform af de erhvervsrettede uddannelser (omtalt i afsnit 2.2.). Styregruppen skulle bl.a. foreslå nye modeller for administration, styring og finansiering. Gruppen omfattede dels repræsentanter for ministerier (Undervisnings- og Kulturministeriet, Arbejdsministeriet og Social og Sundhedsministeriet), dels repræsentanter for arbejdsmarkedets parter. Styregruppen forventes at afslutte sit arbejde med udgangen af 2010. Forberedelsen af totalreformen skulle dog være færdig tidsnok til at implementeringen af reformen kunne påbegyndes 1. januar 2009 (Undervisnings- och kulturministeriet 2007). Som støtte til styregruppen nedsatte Undervisningsministeriet desuden en samarbejdsgruppe med repræsentation fra "centrala aktörer" (Undervisnings- och kulturministeriet 2007).

Rådet for Arbejds-, Erhvervs- og Uddannelsesforhold, der er et trepartsudvalg under Arbejds- og Erhvervsministeriet samt Undervisningsministeriet, er nedsat for en treårig periode fra og med september 2008. Det har til opgave at beskæftige sig med centrale uddannelses- og arbejdsmarkedspolitiske analyser og strategier blandt andet vedrørende udvikling af uddannelsesområdet. Ligeledes i 2008 blev der nedsat en komité, der skulle forberede en reform af folkeoplysningsområdet med repræsentation fra organisationerne for udbyderne af folkeoplysning (Undervisnings- och kulturministeriet 2009).

I 2009 blev Rådet for Livslang læring etableret for perioden 20092011 som et ekspertorgan i tilknytning til Undervisnings- og kulturministeriet. Rådet har til formål at beskæftige sig med forudsætningerne for livslang læring, udvikling af voksenuddannelsespolitikken samt fremme af samspillet mellem uddannelse og arbejdsliv. Sammensætningen af dette råd, hvor formanden er hentet fra en lønmodtagerorganisation og næstformanden fra uddannelsesforskningen, er bred: De øvrige 14 medlemmer kommer fra arbejdsmarkedets parter, nationale, regionale og lokale myndigheder, uddannelsesinstitutionernes organisationer og de studerendes organisation. Statens repræsentanter beskrives som „eksperter“ - ikke 
som embedsmænd - og de er rekrutteret fra det nationale uddannelsesråd og fra ministerierne for undervisning, beskæftigelse og økonomi samt social- og sundhedsområdet. Arbejdspladslæring, unge uden uddannelse og udviklingen af en ny national strategi for livslang læring er væsentlige punkter på det nye råds dagsorden. (Undervisningsministeriet 2009c).

Udover diverse råd og udvalg har arbejdsmarkedets parter også været involveret i forberedelsen af voksenuddannelsespolitikken gennem deltagelse i blandt andet seminarer. Som eksempel kan nævnes konferencen Livslang læringspolitik 2012, der blev afholdt i februar 2007 som et samarbejde mellem Undervisningsministeriet og Arbejdsministeriet. Konferencens fokus var forberedelse af et nyt udviklingsprogram for uddannelse og forskning samt udvikling af en strategi for livslang læring (Ministry of Education 2007).

\subsubsection{Island}

Der er i Island en lang tradition for inddragelse af arbejdsmarkedets parter med hensyn til voksenuddannelse (Friberg \& Modig, 2010). Det gælder også i forhold til livslang læring. Ifølge den islandske rapport til EU om implementeringen af livslang læring fra 2009, er der blandt arbejdsmarkedets parter således en fælles forståelse af nødvendigheden af livslang læring, og parterne har indgået et samarbejde blandt andet med henblik på en generel forøgelse af befolkningens uddannelsesniveau. Arbejdsmarkedets parter er desuden involveret i voksenuddannelserne som udbydere af uddannelse, som også beskrevet i afsnit 2.3 (Iceland: National Report on the Implementation of the Education and Training 2010 Work Programme, 2009).

I 1998 oprettedes Mennt („Educate Iceland“), der er et forum for samarbejde mellem blandt andet uddannelsessektoren, arbejdsmarkedets parter og kommunerne. Samme år offentliggjorde Undervisningsministeriet en femårsplan for livslang læring. I planen fremhæves ikke alene regeringens men også arbejdsmarkedets parters ansvar for den livslange læring (Stefánsdottir, 2001). Mennt er blandt andet arrangør af den årlige uge for livslang læring.

Arbejdsmarkedets parter deltog desuden i forberedelserne af Lov om voksenuddannelse fra 2010, jf. afsnit 3.2.3 neden for, ligesom de er repræsenteret i bestyrelsen for den efteruddannelsesfond, der oprettes som følge af loven (Althingi, 2010). 
Endelig deltager arbejdsmarkedets parter i beskæftigelsesrådene, der har til formål at rådgive undervisningsministeren vedrørende erhvervsuddannelse, og nedsættes for fem år ad gangen (Friberg \& Modig, 2010).

\subsubsection{Norge}

I Norge opnåede arbejdsmarkedets parter en væsentlig indflydelse på kompetencepolitikkens udformning. Dette skyldtes først og fremmest de tætte realtioner mellem LO og Arbeiderpartiet (Mailand 2009). Som eksempel kan nævnes det forløb, der startede i 1993, hvor LO vedtog en strategi for kompetencepolitikken i Norge. Denne vedtagelse medførte hurtigt, at Stortingets flertal vedtog et forslag, der forpligtede regeringen til at udvikle en kompetencepolitik. Resultatet blev nedsættelsen af en national komité med stærk repræsentation fra arbejdsmarkedets parter (Tøsse 2005). Også i forbindelse med kompetencereformen fra 1999 spillede arbejdsmarkedets parter en væsentlig rolle. Reformen var således blandt andet en følge af længerevarende diskussioner mellem arbejdsmarkedets parter om finansieringen af uddannelsesorlov for ansatte (Ure 2007). I forbindelse med kompetencereformen blev der iværksat et kompetenceudviklingsprogram. Programmet var ifølge Døving og Skule (2002) resultat af et kompromis, hvor arbejdstager organisationerne accepterede en moderat lønpolitik mod en øget satsning på kompetenceudvikling. Dette indebar ifølge Døving og Skule en stærk følelse af ejerskab til programmet hos arbejdsmarkedets parter. Et forhold, der forstærkedes fordi programmet blev ledet af et udvalg, hvor staten var repræsenteret, men arbejdsmarkedets parter dominerede (Døving \& Skule 2002).

Ifølge Ure (2007) var der imidlertid i de ydre lag af organisationerne ikke den samme interesse for udvikling af kompetencereformen, og reformen har efter hans mening næppe ført til en styrkelse af samarbejdet mellem parterne. Arbejdsmarkedets parters involvering i reguleringen af efter- og videreuddannelse er derfor mindre omfattende end deres involvering i de grundlæggende erhvervsuddannelser, hvilket lægger en stor del af ansvaret på statens skuldre.

\subsubsection{Sverige}

Da Sverige i 2007 - senere end Danmark og Finland - vedtog at nedsætte et globaliseringsråd, valgte man at inddrage arbejdsmarkedets parter. 
Rådets opgave har været på baggrund af forskellige analyser at komme med forslag til økonomisk-politiske strategier, der skulle styrke Sveriges stilling i den globale konkurrence. Rådet bestod blandt andet af repræsentanter for arbejdsmarkedets parter, samt forskere og politikere. Rådet præsenterede resultatet af sit arbejde i en slutrapport i 2009 (Globaliseringsrådet 2009).

\subsection{Indholdet i de nationale strategier, herunder særlige indsatsområder}

Med reference til Lissabonstrategien vedtog EU-kommissionen i 2006 en meddelelse om voksenuddannelse, „Voksenuddannelse: Det er aldrig for sent at lære" (Kommissionen for de europæiske fællesskaber, 2006). I meddelelsen blev voksenuddannelse fremhævet som en væsentlig del af livslang læring. Voksenuddannelse blev i meddelelsen defineret som:

„alle former for læring, som voksne indgår i, efter at de har forladt den oprindelige grunduddannelse og faglige uddannelse, uanset hvor lang deres uddannelse har været (dvs. inklusive videregående uddannelse)“ (Kommissionen for de europæiske fællesskaber 2006, s. 2).

Det blev desuden fremhævet, at voksenuddannelse udover at bidrage til den enkeltes personlige udvikling og udnyttelse af evner også er afgørende for at nå Lissabonstrategiens mål om stigende økonomisk vækst, konkurrenceevne og social integration (Kommissionen for de europæiske fællesskaber 2006, s. 2). De overordnede mål i strategien var:

- Fjernelse af hindringer for deltagelse i voksenuddannelse

- Sikring af voksenuddannelsernes kvalitet

- Anerkendelse og validering af uddannelsernes resultater

- Investering i den aldrende befolkning og indvandrere

- Indførelse af indikatorer og benchmarking

En oversigt over deltagelsen i voksenuddannelse viste samtidig, at de fem nordiske lande alle lå blandt de seks lande, der havde den højeste deltagelsesfrekvens (Kommissionen for de europæiske fællesskaber, 2006). 
Meddelelsen blev i 2007 fulgt op af en handlingsplan for voksenuddannelse, „Handlingsplan for voksenuddannelsen: Det er altid et godt tidspunkt at lære" (Kommissionen for de europæiske fællesskaber, 2007). Fokus i handlingsplanen var dem, der var dårligst stillede på grund af „dårlige læse- og skrivefærdigheder, utilstrækkelige arbejdskvalifikationer og/eller kompetencer, der ikke kan integreres fuldt ud i samfundet" (Kommissionen for de europæiske fællesskaber 2007, s. 4). Med henblik på at styrke voksenuddannelsesområdet opfordrede kommissionen medlemslandene til at tage initiativer inden for områderne:

- Analyser af virkningerne af reformer med hensyn til voksenuddannelse

- Forbedre undervisningskvaliteten

- Bedre mulighed for voksne for at få en højere kvalifikation, der er mindst et niveau højere end før

- Fremskyndelse af evalueringsprocessen for kvalifikationer og sociale kompetencer, samt godkendelse og anerkendelse af disse som læringsresultater

- Forbedret overvågning af voksenuddannelsessektoren

Endelig offentliggjorde Rådet for den europæiske union i 2008 deres konklusioner vedrørende voksenuddannelse (Rådet for den europæiske union 2008). Af disse fremgår det, at medlemsstaterne frem til 2010 i samarbejde med kommissionen opfordres til at fremme udbuddet af og efterspørgslen efter voksenuddannelse. Dette skal blandt andet ske ved hjælp af et øget samarbejde mellem erhvervslivet og uddannelsesudbyderne, samt gennem et øget fokus på de kortest uddannede. Der lægges endvidere i konklusionerne vægt på individuel kompetencevurdering og karrierevejledning, samt på en aktiv inddragelse af arbejdsmarkedets parter og andre interessenter.

I midtvejsrapporten for Lissabonstrategien fra 2004, „Uddannelse og erhvervsuddannelse 2010, Lissabonstrategiens succes afhænger af gennemførelsen af hastende reformer“, opfordrede Rådet medlemslandene til senest i 2006 at have udarbejdet og gennemført „sammenhængende og omfattende strategier for livslang læring" (Rådet for den europæiske union 2004, s. 24). Det følgende bygger overvejende på indholdet i disse strategier fra såvel de tre nordiske EU-medlemslande (Danmark, Finland og Sverige) som fra de to EØS-lande (Island og Norge). 


\subsubsection{Danmark}

Danmarks strategi for livslang læring (Undervisningsministeriet 2007) bygger i høj grad på globaliseringsstrategien, den politiske aftale om etablering af en globaliseringsfond samt anbefalingerne fra trepartsudvalget for livslang opkvalificering og uddannelse for alle på arbejdsmarkedet. Ifølge forordet til strategien er det overordnede formål med de igangsatte reformer, at sikre kvalitet og sammenhæng i det danske uddannelsessystem, fra grundskole til videregående uddannelse samt voksen- og efteruddannelse. Der lægges med hensyn til voksenuddannelse i strategien vægt på uddannelse, der er relevant for arbejdsmarkedet, hvad enten der er tale om almen voksenuddannelse eller direkte erhvervsrettet voksenuddannelse, mens folkeoplysningen ikke er i fokus. Der lægges i strategien desuden vægt på udvikling af såvel udbud af som efterspørgsel efter voksenuddannelse, med et særligt fokus på de kortuddannede og andre udsatte grupper, for eksempel tosprogede.

De centrale elementer i strategien er:

- Vejledning og rådgivning over for beskæftigede og virksomheder

- Anerkendelse af realkompetencer

- Øget deltagelse i læse-, skrive- og regnekurser for voksne

- Bedre tilbud til tosprogede

- Mere „attraktive, målrettede og fleksible“ arbejdsmarkedsuddannelser

- Flere kompetencegivende voksenuddannelser på videregående niveau

- Flere voksenlærlinge

- Ny model for finansiering af de erhvervsrettede voksen- og efteruddannelser (mere fleksibel brugerbetaling)

- Systematisk kompetenceudvikling i små og mellemstore virksomheder

- Øgede offentlige og private investeringer i voksen- og efteruddannelse

- Øget overvågning af området på baggrund af indikatorer

Med hensyn til folkeoplysningen lægger strategien op til udvikling af prøveforberedende og kompetencegivende undervisning på folkehøjskolerne, samt øget anerkendelse af realkompetencer opnået gennem deltagelse i folkeoplysning og foreningslivet.

Siden 2007 har der i dansk voksenuddannelsespolitik primært været fokus på vejledning og rådgivning samt på anerkendelse af realkompetencer som et middel til at fremme livslang læring (Milana \& Larson, 2010). 


\subsubsection{Finland}

Der skelnes i Finland mellem voksenuddannelse, der hører under Undervisningsministeriet, og arbejdsmarkedspolitisk uddannelse, der hører under Arbejdsministeriet og primært er rettet mod arbejdsløse eller personer over 20 år i risiko for at blive arbejdsløse. Arbejdsministeriet udbyder ikke selv undervisning, men køber uddannelse hos uddannelsesinstitutionerne og andre udbydere. Der er som regel tale om kortere kurser og efteruddannelse, men der kan også være tale om eksamensforberedende uddannelse (Undervisnings- och kulturministeriet, u.å,).

Det finske Undervisnings- og kulturministerium udgiver hvert fjerde år en plan for uddannelse og forskning. I tiden siden 2000 er der udgivet to sådanne planer.

Finlands målsætning i forhold til livslang læring blev beskrevet i en udviklingsplan, der dækkede perioden 2003-2008. Hensigten med femårsplanen var dengang at sikre landet en arbejdskraft, der besad de kompetencer, der var nødvendige af hensyn til konkurrenceevnen og at udvikle medborgerskab i befolkningen. Dette skulle ske ved at hæve det generelle uddannelsesniveau. Et af målene var at øge deltagelsen i livslang læring fra $54 \%$ af den voksne befolkning i 2000 til $60 \%$ i 2008. Udviklingsplanen lagde særligt vægt på initiativer rettet mod de kortest uddannede. Desuden spillede vejledning og rådgivning af voksne en central rolle. Udviklingsplanen lagde endvidere vægt på den formelle voksenuddannelse. Der skulle i den forbindelse sikres et tilstrækkeligt udbud af uddannelse fokuseret på udvikling af færdigheder af relevans for informationssamfundet. Reformen omhandlede voksenuddannelse fra ungdomsuddannelsesniveau (gymnasium og erhvervsuddannelse) til universitetsuddannelse (Ministry of Education 2004).

Den næste femårsplan for perioden 2007-2012 udkom i 2008 (Undervisnings- och kulturministeriet 2008). Udviklingsplanen for 2007-2012 beskriver fem indsatsområder:

- Lige uddannelsesmuligheder

- Uddannelsens kvalitet

- Sikring af kvalificeret arbejdskraft

- Udvikling af de videregående uddannelser

- Lærerne som ressource 
Voksenuddannelsesområdet fremhæves blandt andet i forbindelse med de lige uddannelsesmuligheder som et middel til at støtte den enkeltes muligheder for at tage del i samfundet og arbejdslivet. Det skal ifølge planen desuden sikres, at de voksnes kompetence- og uddannelsesniveau opretholdes og udvikles, blandt andet gennem en sikring af, at „intelligensreserven“ blandt indvandrerne anvendes fuldt ud. I lighed med den forrige udviklingsplan, sættes målet for indsatsen inden for voksenuddannelsesområdet til, at mindst $60 \%$ af den voksne befolkning i den arbejdsduelige alder, skal deltage i uddannelse. På den baggrund lægger udviklingsplanen blandt andet op til den tidligere omtalte (kapitel 2.2) totalreform af den erhvervsrettede voksenuddannelse. Formålet med reformen er at skabe gennemsigtighed i forvaltningen, finansieringen og udbuddet af den erhvervsrettede voksenuddannelse. Med erhvervsrettet voksenuddannelse henvises i den forbindelse til erhvervsuddannelse for voksne, voksenuddannelse ved högskolerne, „arbetskraftspolitisk“ voksenuddannelse samt personaleuddannelse som arbejdsgiveren betaler og arrangerer. Som led i reformen skal der i lighed med den tidligere reform lægges vægt på information, rådgivning og vejledning. Desuden fremhæver reformen læring i jobbet (Ministry of Education 2008; Undervisnings- och kulturministeriet 2008).

Ved siden af reformen af den erhvervsrettede voksenuddannelse er der som nævnt i afsnit 3.1.2 igangsat en reform af den folkeoplysende voksenuddannelse. Komitéen bag reformen foreslår i deres midtvejsrapport fra 2008 blandt andet en øget vægt på global tænkning og kulturel mangfoldighed. Komitéen foreslår desuden, at finansieringen af de folkeoplysende voksenundervisninger fremover skal baseres på en kombination af en basisbevilling og kvalitets- og udviklingsmidler (Undervisningsoch kulturministeriet 2009). Der skal i udviklingen af den folkeoplysende voksenundervisning desuden lægges vægt på de sproglige færdigheder blandt indvandrere (Ministry of Education 2008).

\subsubsection{Island}

Selv om Island ikke er medlem af EU, har Island, som omtalt i afsnit 2.3, på mange områder efterlevet retningslinjerne fra EUs arbejdsprogram „Education and Training 2010" inden for grundskole- og ungdomsuddannelsesområdet, men har ikke anset det for relevant med en særlig strategi for livslang læring. 
Det islandske parlament har dog i 2010 vedtaget en lov om voksenuddannelse. Der lægges i loven særlig vægt på de kortuddannede samt uddannelse, der har til formål at fremme den enkeltes beskæftigelsesegnethed, samt aktive medborgerskab. Loven indebærer desuden oprettelse af en efteruddannelsesfond, der blandt andet kan yde tilskud til fornyelse og udvikling inden for efteruddannelsesområdet. Loven er trådt i kraft pr. 1. oktober 2010 (Althingi 2010).

\subsubsection{Norge}

Norge har i lighed med Island langt hen ad vejen fulgt EUs anbefalinger, selv om landet ikke er medlem. Politikken med hensyn til livslang læring og voksenuddannelse i Norge er i høj grad et resultat af kompetencereformen fra 1999 (Døving \& Skule 2002; Ure 2007). Med reformen ønskede Norge at leve op til de internationale anbefalinger vedrørende livslang læring fra organisationer som UNESCO, ILO, OECD og EU. Det overordnede mål med kompetencereformen var ifølge Døving og Skule, at „bidra til å dekke samfunnets, arbeidslivets og den enkeltes behov for kompetanse“ (Døving \& Skule 2002, s. 5). Som led i reformen blev der som omtalt i kapitel 2.4 iværksat et kompetenceudviklingsprogram (KUP), der gav økonomisk støtte til relevante projekter. Formålet med programmet var:

- At gøre virksomhederne bedre til at identificere, udtrykke og opfylde deres kompetencebehov

- At skabe arenaer for samarbejde mellem virksomheder og uddannelsesinstitutioner/-udbydere

- At udvikle efter- og videreuddannelsestilbud, der i højere grad var tilpasset arbejdsmarkedets behov

(Døving \& Skule 2002)

Udover oprettelsen af kompetenceudviklingsprogrammet, indebar kompetencereformen også en individuel ret til uddannelsesorlov, et system for dokumentation og validering af non-formel og uformel læring, samt en ret til videregående uddannelse for voksne. Dette blev et par år senere udvidet til også at omfatte uddannelse på grundskoleniveau. Mens ansvaret for den videregående voksenuddannelse blev placeret under fylkerne, var det kommunerne, der var ansvarlige for grundskoleuddannelsen. De kunne dog vælge at lade studieforbund, fjernundervisningsinstitutioner eller 
andre stå for den praktiske afvikling af undervisningen (European Commission 2007; NOU 2001:25).

I 2006/2007 iværksatte regeringen en række tiltag, kaldt Kunnskapløftet for voksne. Tiltagene omfattede blandt andet et program for basiskompetencer i arbejdslivet (BKA), og en informations- og motivationskampagne om voksnes rettigheder og værdierne i relation til deltagelse i uddannelse (European Commission 2007).

Fokus i norsk voksenuddannelsespolitik har siden 2000 været på udvikling af basiskompetencer hos voksne, anerkendelse af non-formel og uformel læring, mere fleksible læringsmetoder og -arenaer, karrierevejledning, samt et øget samarbejde mellem uddannelse og arbejdslivet, blandt andet gennem et øget fokus på arbejdslivet som læringsarena.

Som den nyeste udvikling, har Norge vedtaget en ny lov om voksenuddannelse, der trådte i kraft 1. januar 2010 (Kunnskapsdepartementet 2009b). Formålet med loven er ifølge § 1, „å fremme livslang læring ved å legge til rette for organiserte læringsaktiviteter ved siden av det formelle utdanningssystemet." Loven er altså rettet mod non-formel uddannelse og fastsætter regler for statstilskud til studieforbund og net-skoler (fjernundervisning).

\subsubsection{Sverige}

Blandt anbefalingerne i Globaliseringsrådets første rapport fra 2007, var blandt andet et øget fokus på uddannelse, med særlig vægt på at højne uddannelsesniveauet, samt på voksenuddannelse. I den forbindelse blev også statens rolle fremhævet: „Staten måste väl sköta sina grunduppgifter, däribland att främja höjd utbildningsnivå och att människor under sin yrkesversamma tid får återkommande möjligheter till utbildning" (Utbildningsdepartementet 2007, s. 24). Også i rådets afsluttende rapport fra 2009 fremhæves behovet for voksenuddannelse, hvis Sverige skal stå godt i den globale økonomi. Det fremhæves således, at et lands mulighed for at udvikle sig i høj grad afhænger af voksnes muligheder for at udvikle deres kompetencer. For at øge deltagelsen i voksenuddannelse foreslår rådet, at der indføres individuelle kompetence-konti finansieret af blandt andet 
staten ved siden af det eksisterende studiestøttesystem ${ }^{4}$ (Globaliseringsrådet 2009).

Et af de nyeste initiativer inden for voksenuddannelsesområdet er oprettelsen af "Yrkeshögskolan“ i 2009. Med etableringen af yrkeshögskolan samles en del efter- og videreuddannelse, lærlingeuddannelser for voksne samt nogle kvalificerende erhvervsuddannelser for voksne under samme lov. Uddannelserne under yrkeshögskolarne skal være præget af såvel en stærk tilknytning til arbejdsmarkedet som teoretisk funderede, og de skal udvikles i et samarbejde mellem virksomheder og uddannelsesudbydere (Regeringen 2008).

\subsection{Diskussion}

På baggrund af det tætte samarbejde mellem arbejdsmarkedets parter og de nordiske stater i forbindelse med arbejdsmarkedspolitikken, er det næppe overraskende, at der også har været et nært samarbejde i forbindelse med udformningen af strategier om livslang læring og voksenuddannelse. I alle de fem nordiske lande har arbejdsmarkedets parter, som det fremgår oven for, således været inddraget ikke alene i politikudformningen men også i den senere implementering enten via repræsentation i de styrende organer for de erhvervsrettede uddannelsesinstitutioner som i Danmark, eller som direkte udbydere af uddannelse, som det ses i Island. Udover arbejdsmarkedets parter, har der i nogle tilfælde også været tale om en inddragelse af repræsentanter for uddannelsesinstitutionerne. Det har for eksempel været tilfældet i Finland, hvor uddannelsesinstitutionerne har været repræsenteret i diverse udvalg på linje med arbejdsmarkedets parter.

Et andet træk, der går igen i forbindelse med udviklingen af de nordiske landes strategier for livslang læring og voksenuddannelse, er et gennemgående samarbejde mellem de uddannelsespolitiske og arbejdsmarkedspolitiske myndigheder. Et forhold, der i lighed med inddragelsen af arbejdsmarkedets parter afspejler voksenuddannelsens øgede betydning som arbejdsmarkedspolitisk redskab.

\footnotetext{
${ }^{4}$ Forslaget om at indføre individulle kompetencekonti er dog endnu ikke gennemført.
} 
Selv om kun tre af de nordiske lande er medlemmer af EU, bærer strategierne og planerne for livslang læring og voksenuddannelse i alle fem lande præg af fokusområderne i EUs Lissabonstrategi. Et gennemgående træk er et ønske om at øge voksnes deltagelse i uddannelse. Et forhold, der kan virke paradoksalt i betragtning af, at de nordiske lande generelt ligger i toppen på europæisk plan, netop når det gælder andelen, der deltager i voksen- og efteruddannelse. Ønsket om at øge deltagelsen i voksenog efteruddannelse kobles imidlertid generelt sammen med et fokus på de grupper, der deltager mindst i voksenuddannelse; typisk de kortest uddannede samt tosprogede.

Gennemgående for strategierne er desuden et fokus på uddannelser af relevans for arbejdsmarkedet. Det fremgår særligt tydeligt i den danske strategi, der blandt andet bygger på arbejdet i udvalget med det sigende navn „Trepartsudvalget for livslang opkvalificering og uddannelse for alle på arbejdsmarkedet" (vores understregning).

I de senere strategier er der særligt fokus på anerkendelse af realkompetencer samt på vejledning/rådgivning.

Selv om fokus i strategierne og planerne således langt hen ad vejen synes at være det samme i de fem nordiske lande, er der stor forskel på, hvordan de præsenteres. På trods af, at alle fem lande har afleveret en rapport til EU om deres strategi for livslang læring, er det i flere tilfælde vanskeligt at finde én overordnet strategi for livslang læring. I stedet er der snarere tale om en række strategier og reformer. I nogle tilfælde er der et særligt fokus på voksenuddannelse, mens voksenuddannelse i andre tilfælde blot er en del af en samlet strategi for og reform af hele uddannelsessystemet. Det hænger muligvis blandt andet sammen med de forskellige organiseringer af uddannelsessystemet, hvor voksenuddannelse ikke altid er klart adskilt fra de øvrige dele af uddannelsessystemet.

\subsection{Delkonklusion med anbefalinger}

På baggrund af det formaliserede samarbejde mellem staten og arbejdsmarkedets parter kan det næppe overraske, at de nordiske lande har benyttet denne model, da der skulle udformes strategier for livslang læring og voksenuddannelse. Inddragelsen af arbejdsmarkedets parter i udviklingen af voksenuddannelsespolitikken må antages at bidrage til en øget følelse af ansvarlighed for implementeringen af strategierne. Samtidig er 
det væsentligt at være opmærksom på, at støtten fra centralt hold i de faglige organisationer og arbejdsgiverorganisationerne ikke nødvendigvis deles længere nede i systemet, som fremhævet af Ure (2007) i forbindelse med Norge. Arbejdsmarkedets parter står således over for en væsentlig opgave i forhold til at „sælge“ idéen om livslang læring og voksenuddannelse samt de mere konkrete elementer i strategierne til de decentrale lag af organisationerne og medlemmerne.

Med hensyn til fokusområderne i strategierne for livslang læring og voksenuddannelse kan det desuden konkluderes, at det er vanskeligt at finde en egentlig samlet strategi for livslang læring. Det skal ikke tages som udtryk for, at der ikke er interesse for den livslange læring og voksenuddannelsesområdet, men snarere for, at udviklingen har været præget af en løbende række af planer og reformer. På trods af dette, er det dog muligt at identificere en række fællestræk på tværs af de fem nordiske lande. Det drejer sig blandt andet om et fokus på uddannelser af relevans for arbejdsmarkedet, hvilket må siges at være i fin overensstemmelse med inddragelsen af arbejdsmarkedets parter i processen. Livslang læring og voksenuddannelse er således i de nordiske lande i dag i høj grad et arbejdsmarkedspolitisk redskab. Desuden er det generelt et fokus på at øge deltagelsen blandt kortuddannede og tosprogede.

I det ovenstående har der været sat fokus på de overordnede strategier, således som de er beskrevet i forskellige policy papers. Som opfølgning herpå anbefales det at:

- Der igangsættes en udredning af den konkrete udmøntning af disse mere overordnede strategier og betydningen for deltagelsen i voksenog efteruddannelse

- Der iværksættes en undersøgelse af, hvilken betydning støtten fra de centrale dele af arbejdsmarkedets parter har for deltagelsen i voksenog efteruddannelse, herunder i hvilket omfang støtten deles af medlemmerne af organisationerne 


\section{Samspillet mellem uddannelsesinstitutioner og virksomheder}

\subsection{Uddannelsessystem vs. arbejdsliv}

Da de nordiske lande i 1960erne begyndte at udvikle systemer, der skulle give voksne mulighed for at komme i uddannelse, fulgte regeringerne $\mathrm{i}$ almindelighed tre spor:

- Et statsligt erhvervsrettet spor for korte kurser, der var forankret i et arbejdsministerium

- Et kommunalt alment eksamensforberedende spor, der var forankret $\mathrm{i}$ et undervisningsministerium

- Et ikke-offentligt folkeoplysende spor, der var forankret i frivillige organisationer, der modtog statstilskud

I dag kan vi stadig skimte disse spor, men det omgivende samfund, herunder arbejdslivet er afgørende forandret, og det indebærer, at rammer og vilkår for voksne brugere af systemerne er blevet anderledes. De aktiviteter, der modtager offentlig støtte, er blevet omfattende, de nationale modeller har fået andre strukturer og forankringen i statslige, regionale og kommunale myndigheder er blevet ændret. Telhaug, Mediås og Aasen (2004), der har foretaget historisk-komparative studier af dansk, norsk og svensk uddannelsespolitik, fremhæver, at kommunernes vilkår og rammer er ændret. I løbet af 1960erne faldt antallet af kommuner: I Danmark fra 1.388 til 275, i Norge fra 744 til 443 og i Sverige fra 2.498 til 284. Siden er nye omfattende kommunesammenlægninger gennemført, og de store kommuner, som vi kender i dag, har fået nye opgaver. Også regionerne (amter, len, fylker) er blevet færre, og deres arbejdsdeling i forhold til staten og kommunerne er blevet ændret. 
De statslige ministerier, styrelser m.v. har fået nye opgaver, men visse nationale strategier synes at være uændrede. Der er - i en kortlægning af samspillet mellem uddannelsessystem og arbejdsliv - afgørende forskel mellem i Danmark og Finland: De to lande er p.t. hinandens modsætninger inden for et nordisk kontinuum: Finland har slået ministerierne for arbejde og økonomi sammen, mens Danmark har flyttet arbejdsmarkedsuddannelserne fra Arbejdsministeriet til Undervisningsministeriet.

Allerede i 2001 var der, ifølge en sammenligning af de nationale strategier vedrørende realkompetencevurdering markant forskel på de to lande: Mens Finland ønskede at udvikle en model, der kunne gøre den enkelte arbejdstager attraktiv i forhold til arbejdsmarkedet, foretrak Danmark en model, der kunne få uddannelsessystemet til at godskrive kompetencer, der var udviklet i arbejdslivet (Nordisk Ministerråd, 2001b).

\subsubsection{Arbejdsdelingen mellem stat, region og kommune}

De nationale uddannelsessystemer i de nordiske lande stillede i 1990erne om til „decentralisering“ og „deregulering." Kommuner og regioner var blevet større gennem sammenlægninger, de udviklede egentlige uddannelsesforvaltninger, og deres uddannelsesinstitutioner fik mere autonomi. Denne proces er blevet kortlagt og analyseret af Telhaug, Mediås og Aasen (2004). Deres forskning drejer sig imidlertid især om forholdet mellem grundskoler og kommuner, mens de systemer, der beskæftiger sig med voksnes læring, især er styret af regionale myndigheder. Det er logisk, at regionerne måtte udvikle selvstændige strategier for deres egne uddannelsesinstitutioner, og det antages, at en del regioner har valgt at give de unges læring højeste prioritet. Hvis de voksne brugere kommer i anden række, når regionerne lægger budgetter, vil systemerne for voksne udvikle sig langsommere end systemerne for unge.

Der var i 1980erne politisk vilje til at adskille voksne brugere fra unge brugere og til at etablere uddannelsesinstitutioner med en „voksenprofil.“ Dette skete i samklang med datidens forskning, der var optaget af „voksenpædagogik“ (andragogik), og denne tænkning fik konkret udtryk gennem udarbejdelsen af særlige læreplaner for voksne (Lumsden Wass 2004). I 1990erne medførte sammenlægninger af uddannelsesinstitutioner i en del regioner, at uddannelsesinstitutionerne fik både unge og voksne som brugere. Dette gælder f.eks. for de uddannelsesinstitutioner i Danmark, der udbyder „højere forberedelseseksamen.“ En anden afgøren- 
de forandring var, at nationale læreplaner nu blev udarbejdet på basis af en tænkning i niveauer for „learning outcomes.“ Dvs. de offentlige retningslinjer for voksnes, unges og børns læring kan - hvis niveauerne for slutmålene er de samme - være en og samme tekst. Tendensen til at fusionere uddannelsesinstitutioner og myndighedernes anvendelse af certificering/akkreditering har medført, at antallet af uddannelsesinstitutioner der er relevante for voksne, er blevet reduceret, og læreplaner designet for voksne er ved at blive sjældne.

Der kendes eksempler på kommuner, der har nedprioritet voksne brugere. Den norske Riksrevisjon offentliggjorde i 2008 en undersøgelse af kommunernes forvaltning af de voksnes rettigheder til kompetenceudvikling på grundskoleniveau og påpegede en række kritisable forhold. Enkelte kommuner havde undladt at afsætte ressourcer til voksnes læring, og en del havde forsømt deres informationsforpligtelser. Riksrevisionens vurdering var, at statens tilsyn havde været utilstrækkeligt, og at relationen mellem Utdanningsdirektoratet og Vox, direktoratets fagorgan havde været uklar (Riksrevisjonen, 2008).

\subsubsection{Det nationale marked for voksnes kompetenceudvikling}

I de nordiske lande har New Public Management (NPM) spillet en væsentlig rolle for de offentlige forvaltninger (Ståhlberg og Klausen, 1998), og det giver god mening at tale om nationale markeder for voksen- og efteruddannelse og kompetenceudvikling.

De uddannelsesudbydere, der sælger ydelser til voksne brugere, kan opdeles i tre kategorier: De private, de offentlige og de „semi-offentlige.“ Den tredje kategori eksisterer i mere eller mindre tydelig form i alle landene, og den kan beskrives som en sektor, der modtager faste offentlige tilskud og er underkastet et offentligt tilsyn uden at være ejet af staten, regionen eller kommunen. Som eksempel på den tredje kategori kan nævnes de "folkeoplysende“ og de „selvejende“ uddannelsesudbydere.

Køberne på det nationale marked for kompetenceudvikling er virksomheder, og disse købere kan opdeles i tre kategorier: De private, de offentlige og de „semi-offentlige.“ Den tredje kategori af købere kan f.eks. være tidligere offentlige institutioner, der er blevet omdannet til aktieselskaber, hvor det offentlige ejer aktiemajoriteten. Mulighederne for samspil mellem de seks kategorier kan opstilles således: 


\begin{tabular}{llll}
\hline & \multicolumn{2}{c}{ Sælgere } \\
\cline { 2 - 3 } & $\begin{array}{l}\text { Private } \\
\text { virksomheder }\end{array}$ & $\begin{array}{l}\text { Offentlige uddan- } \\
\text { nelsesinstitutioner }\end{array}$ & $\begin{array}{l}\text { Semi-offentlige uddan- } \\
\text { nelsesinstitutioner }\end{array}$ \\
\hline \multirow{2}{*}{$\begin{array}{l}\text { Private virksomheder } \\
\text { Offentlige virksomheder }\end{array}$} & & \\
\hline
\end{tabular}

Det antages, at ejerforhold vil påvirke de salgsaftaler, der indgås på det nationale marked for kompetenceudvikling. Lumsden Wass (2004) har fundet eksempler på, at svenske kommuner foretrækker at handle med deres egne uddannelsesudbydere, og det kan tænkes, at norske fylker er tilbøjelige til at følge det samme mønster.

Forklaringen kan være økonomisk: Hvis den offentligt ejede uddannelsesudbyder mister en forventet kontrakt, vil dens produktion gå ned, hvilket kan medføre afskedigelser og mindre lønsomhed. De reducerede indtægter vil i sidste ende kunne mærkes i kommunens eller regionens økonomi.

Men forklaringen kan også være kulturel: Ledelsen af en offentlig virksomhed vil måske have nemmere ved at forhandle med ledelsen af en offentlig uddannelsesudbyder, fordi deres kulturer (værdier) ligner hinanden. Et norsk studie af de regionale forvaltningers implementering af ny lovgivning om voksnes læring nævner eksempler på, at medarbejdernes holdninger påvirker implementeringen (Engesbak \& Stubbe 2008).

Man kan på den baggrund opstille en hypotese for samspillet mellem sælgere (uddannelsesudbydere) og købere (virksomheder):

Hvis en privat virksomhed køber kompetenceudvikling hos en privat virksomhed (f.eks. et konsulentfirma) er der stor sandsynlighed, for at handlen indgås på markedsvilkår. Hvis en offentlig myndighed køber kompetenceudvikling af en uddannelsesudbyder, der ejes af den samme myndighed, er der mindre sandsynlighed for, at handlen indgås på markedsvilkår. 


\subsection{Rådgivning}

\subsubsection{Rådgivning vs. vejledning}

Vejledning (guidance and counselling), der i Norge kaldes karrierevejledning og i Danmark voksenvejledning betragtes i denne sammenhæng som en gratis serviceydelse, der modtages af voksne medborgere. Karrierevejlederen/voksenvejlederen kan i de nordiske lande være ansat af staten, regionen eller kommunen, men behøver ikke være det. De islandske vejledere er f.eks. ansat af en ikke-offentlig uddannelsesudbyder, og deres aflønning er finansieret af en offentlig bevilling. Det er karakteristisk for vejledning af voksne i de nordiske lande, at serviceydelsen betragtes som en rettighed. Ydelsen er gratis for medborgeren.

De forskellige former for karrierevejledning/voksenvejledning er serviceydelser, der modtages af individuelle brugere. Ofte drejer det sig om at vejlede borgeren i forhold til voksen- og efteruddannelse og kompetenceudvikling, men serviceydelsen omfatter mere end det. I de nordiske lande spiller medborgerens personlige situation også en rolle.

Rådgivning (consulting) betragtes i dette studie som en serviceydelse, der ydes virksomheder. Den kan være gratis, men behøver ikke være det. F.eks. yder private konsulentvirksomheder rådgivning mod betaling, mens de konsulenter, der laver opsøgende virksomhedsrådgivning for de semioffentlige VEU-centre i Danmark, ikke opkræver betaling. Dette studie beskæftiger sig kun med den rådgivning, der er gratis.

Det er virksomhederne, der modtager rådgivning, og der er oftest tale om „small and medium size enterprises“ (SME). Dette studie beskæftiger sig med SME, fordi der samlet set er relativt få store virksomheder i de nordiske lande. EU har særlige programmer for udvikling af SME, og siden den 1. januar 2005 har EU- og EØS-landene anvendt en fælles SME-definition. De nordiske lande har erhvervspolitikker, der forholder sig til SME.

Store virksomheder vil ofte have interne rådgivere eller en HRafdeling, der forholder sig til behovet for voksen- og efteruddannelse og kompetenceudvikling. I en SME er dette område ofte et emne for forhandlinger mellem ledelsen og tillidsrepræsentanterne, og arbejdsmarkedets 
parter har strategier på området. Både $\mathrm{A}-$ og B-siden ${ }^{5} \mathrm{i}$ en virksomhed kan have behov for ekstern rådgivning. Da dette studie kun beskæftiger sig med den rådgivning, der er offentligt finansieret, vil den rådgivning, der ydes af parterne på arbejdsmarkedet, herunder anvendelsen af „uddannelsesambassadører", ikke blive inddraget.

Det antages i dette studie, at professionel voksenvejledning/karrierevejledning og professionel virksomhedsrådgivning bygger på kompetencer, der er forskellige fra hinanden. Dvs. det er to forskellige medarbejdergrupper, der indgår i samspillet mellem uddannelsesinstitutioner og virksomheder. De danske VEU-centre kalder deres virksomhedsrådgivere „konsulenter“.

\subsubsection{Rammer og vilkår for rådgivning af virksomheder}

Studiet har fokus på den rådgivning, der ydes af offentlige institutioner samt den rådgivning, der ydes af semi-offentlige institutioner, der modtager offentlige midler. Det antages, at der er væsentlige forskelle mellem rammer og vilkår for den rådgivning, der ydes af en institution, der har en økonomisk interesse i at få afsat et produkt til en virksomhed, og rammer og vilkår for den rådgivning, der ydes af en institution, der ikke har en sådan interesse.

En kommune eller en region, der ikke ejer uddannelsesinstitutioner, der er relevante for voksne brugere, har ikke økonomisk interesse i, at virksomheden tegner kontrakt med en bestemt uddannelsesinstitution. Dette gælder også på det statslige niveau. Vox, der er en statslig institution i Norge, har f.eks. ikke økonomisk interesse i, at en virksomhed, der inden for BKA-programmet ønsker et partnerskab med en uddannelsesudbyder, vælger en bestemt institution. Men det antages, at der kan opstå interessemodsætninger for de norske regioner (fylker), der ejer uddannelsesinstitutioner og har en interesse i at fastholde deres medarbejdere.

Økonomisk interesse er et relevant tema i forhold til samspillet mellem uddannelsesudbydere og virksomheder, fordi de nordiske lande i almindelighed og i overensstemmelse med NPM og med OECDs rådgivning har ønsket at komme væk fra den udbudsstyring (supply), der var almindelig for voksen- og efteruddannelse i 1980erne. Man har i stedet tilstræbt en

${ }^{5} \mathrm{~A}$-siden og B-siden repræsenterer henholdsvis ledelse og medarbejdere i en virksomhed. 
efterspørgselsstyring (demand). Finland var formodentlig det nordiske land, der først stillede om til en konsekvent efterspørgselsstyring af voksen- og efteruddannelse og kompetenceudvikling (Tuomisto, 1998).

Hensigten med efterspørgselsstyring er at sikre, at uddannelsesudbyderen (den private, den offentlige eller den semi-offentlige) arbejder under markedsvilkår, og det drejer sig ikke bare om at sikre en fornuftig prisdannelse. Det handler også om relevans og kvalitet. Staten vil - i overensstemmelse med NPM - søge at undgå, at uddannelsesinstitutioner forsøger at afsætte produkter (hyldevarer), der er mindre relevante og mindre gode for den pågældende virksomhed. Staten kan gøre en sådan strategi mere effektiv ved at arbejde for, at der er konkurrence mellem de uddannelsesudbydere, der sælger voksen- og efteruddannelse og kompetenceudvikling. I et sådan tilfælde vil det være statens politik, at de private, den offentlige og de semi-offentlige uddannelsesinstitutioner kommer til at konkurrere på lige vilkår. Det indebærer undertiden, at staten må regulere for at sikre en reel konkurrence. Det vurderes, at staten i alle de fem nordiske lande er blevet indstillet på at regulere markedet for voksenog efteruddannelse og kompetenceudvikling.

De virksomheder, der modtager rådgivning, kan være private, offentlige eller semi-offentlige. Antallet af offentlige virksomheder må formodes at være faldende i alle nordiske lande, fordi offentlige virksomheder som f.eks. postvæsen og jernbane bliver privatiseret. Desuden er nogle offentlige virksomheder præget af en tænkning i NPM, og de vil ofte benytte sig af private rådgivningsfirmaer, der kræver betaling for deres serviceydelser.

\subsubsection{Rådgivning og medfinansiering}

Samspillet mellem den uddannelsesinstitution, der yder gratis rådgivning, og den virksomhed, der modtager gratis rådgivning, er et samspil på organisationsniveau. Samspillet kan være tæt og langvarigt, og man kan da tale om et „partnerskab.“ Hvis den rådgivende organisation er offentlig, og den modtagende organisation er privat, bygger samspillet på et „offentligt-privat partnerskab“ (public-private partnership). Hvis samspillet er mindre tæt og mindre langvarigt, kan vi tale om et „netværk“ (Jakobsson 2007).

Når gratis virksomhedsrådgivning ydes af en uddannelsesinstitution, der ønsker at sælge et produkt (kompetenceudvikling) til en virksomhed, og når salget skal foregå på markedsvilkår, er samspillet mellem de to organisationer præget af økonomisk interesse. Den medarbejder fra uddannelses- 
institutionen, der kontakter virksomheden, er både rådgiver og sælger. Dvs. han optræder dels som ekspert i kompetenceudvikling og dels repræsentant for en uddannelsesudbyder, der har en økonomisk interesse i, at der bliver indgået en salgsaftale. Hvis vi sammenligner med en handel, der f.eks. drejer sig om køb og salg af boliger, vil sælgerens ejendomsmægler både være ekspert i ejendomshandel og sælger. Køberen er ikke ekspert i ejendomshandel og sikrer sig derfor ved at benytte en advokat.

En lille eller mellemstor virksomhed (en SME) vil ikke have ansatte, der er eksperter vedrørende voksen- og efteruddannelse og kompetenceudvikling, og derfor vil en SME have behov for rådgivning. Private rådgivere vil ikke kunne levere denne serviceydelse gratis, men det vil offentlige eller semi-offentlige rådgivere ofte kunne, og de vil måske også kunne rådgive om mulighederne for at fremskaffe offentlig medfinansiering. Alle regioner i de nordiske lande vil kunne rådgive en SME om mulighederne for at søge regionale EU-midler. Måske vil det være fordelagtigt for en SME at benytte den gratis rådgivning, som tilbydes af offentlige og semi-offentlige rådgivere. Hvis disse rådgivere er ansat af en uddannelsesinstitution, en kommune eller en region, der har en økonomisk interesse i, at der indgås en salgsaftale, kan der dog opstå en interessemodsætning. Dette problem vil kunne løses ved at købe rådgivning $i$ en privat konsulentvirksomhed.

Hvis gratis virksomhedsrådgivning ydes af en ikke-uddannelsesinstitution - f.eks. en kommune eller en region, der ikke ejer uddannelsesinstitutioner, der opererer på kompetenceudviklingsmarkedet, er samspillet mellem virksomheden og rådgiveren ikke direkte påvirket af økonomiske interesser. Der kan imidlertid være tale om indirekte økonomiske interesser, fordi kommuner og regioner råder over udviklingsmidler, der vil kunne indgå som medfinansiering, hvis virksomheden beslutter sig for at starte et projekt, der omfatter voksen- og efteruddannelse og kompetenceudvikling.

\subsubsection{Strategier for erhvervspolitik og for beskæftigelsespolitik}

Rådgivning af virksomheder finder sted i de nordiske lande, og ofte forsøger man at kombinere hensynet til de kortuddannede (beskæftigelsespolitik) med ønsket om økonomisk vækst (erhvervspolitik). Systematisk opsøgende virksomhedsrådgivning vurderes at være et godt værktøj i begge henseender, og voksen- og efteruddannelse og kompetenceudvikling anses i almindelighed for at være et effektivt middel til at nå de politisk fastsatte mål. 
Regioner og kommuner har policies for økonomisk vækst og for beskæftigelse i SME, og det er derfor naturligt, at offentlige og semioffentlige uddannelsesinstitutioner opbygger netværk eller partnerskaber i forhold til SME regionalt og lokalt. Erfaringer fra de danske „voksenvejledningsnetværk" viser imidlertid, at uddannelsesinstitutionernes muligheder for at satse på begge dele er begrænsede. Det skyldes ikke mindst uddannelsesinstitutionernes forskellige traditioner. De danske VEUcentre - der blev oprettet i januar 2010 - rummer erhvervsskoler, der formodes primært at have været orienteret mod erhvervspolitikken, og AMU-udbydere, der formodes primært at have været orienteret mod beskæftigelsespolitikken. En evaluering af indsatsen, der blev offentliggjort i marts 2010 (Tønder Jessing 2010), viser, at disse uddannelsesinstitutioner har måttet bruge mange kræfter på intern afklaring, hvilket har medført, at de konkrete resultater i forhold til virksomhedernes behov har været sparsomme. Omstillingen fra en tænkning i salg til en tænkning i voksenvejledning/karrierevejledning og virksomhedsrådgivning har taget tid og må tage tid.

Begrebet „opsøgende virksomhed“ blev i 1970erne brugt i Sverige om den individuelle vejledning af voksne på arbejdsmarkedet (Mørch Jacobsen 1982), og i 2010 benyttes det i Danmark om den virksomhedsrådgivning, som VEU-centrene skal udføre. Opgaven er ny for de medarbejdere, der som „konsulenter" henvender sig til virksomheder i lokalområdet eller i regionen. Ifølge evalueringen har man måttet udvikle nye arbejdsformer for kontakten med virksomhederne (Tønder Jessing, 2010). Et samspil på organisationsniveau er anderledes end voksenvejledning/karrierevejledning, der er et samspil på individniveau.

Virksomhedsrådgivning bygger på udbudsstyring - hvis de offentlige og de semi-offentlige uddannelsesinstitutioner benytter begrebet „ops $\varnothing$ gende." Den private virksomhedsrådgivning må i sagens natur være baseret på efterspørgselsstyring.

\subsubsection{Danske modeller}

I 2010 har Danmark reelt to systemer for voksne brugere: VEU-systemet, der betjener de lavere niveauer inden for den nationale kvalifikationsramme (NQF) og Videreuddannelsessystemet for voksne, der betjener de højere niveauer inden for NQF. Videreuddannelsessystemet for voksne er unik i en nordisk sammenhæng - ingen andre nordiske lande er gået så 
langt i forsøget om at give de voksne brugere særlige betingelser, at de har udviklet et parallelt system, der inddrager universiteterne. Dette forklarer, hvorfor det tog fem år at udvikle systemet (Mortensen 2001).

Efter den seneste kommunesammenlægning i 2007 har Danmark 98 kommuner og fem regioner. Kommunerne har oprettet "jobcentre“, der spiller en central rolle inden for den nationale beskæftigelsespolitik. Kommunerne har deres egne strategier inden for erhvervspolitikken, men dette er også et anliggende for de nye regionale „vækstfora.“ Danmark er i lighed med Finland på vej mod at udvikle en politisk styring på to niveauer (Pedersen 2007). Kommunernes borgmestre sidder i de regionale vækstfora, der tilsyneladende ikke prioriterer de voksne brugere af voksen- og efteruddannelse og kompetenceudvikling højt. Således beskriver hjemmesiderne for de fem danske regioner fortrinsvis indsatsen i forhold til unges læring.

Antallet af uddannelsesinstitutioner, der er relevante for voksne brugere af VEU-systemet, er i løbet af de seneste år reduceret fra 140 til 100, og hver af de 100 institutioner indgår i et VEU-center. De 14 VEU-centres samarbejde med regionerne er under opbygning, hvilket fremgår af, at regionernes hjemmesider ikke omtaler voksen- og efteruddannelse og kompetenceudvikling.

Samspillet mellem danske uddannelsesinstitutioner og danske virksomheder er i 2010 præget af, at AMU-udbydere og erhvervsskoler, der har mange relationer til de lokale virksomheder, nu arbejder koordineret med deres samspil med virksomhederne. Dette samspil kan karakteriseres som semi-offentligt/privat, og VEU-systemet ser ud til at bevæge sig fra efterspørgselsstyring mod udbudsstyring.

\subsubsection{Finske modeller}

I Finland er virksomhedsrådgivning og vejledning af voksne brugere et anliggende for det kombinerede økonomi- og beskæftigelsesministerium. Ministeriet blev oprettet i 2008 og fik den 1. januar 2010 - efter omfattende fusioner af offentlige forvaltninger - rådighed over „TE-centraler" ude i landet, hvor et omfattende embedsværk arbejder med tre hovedopgaver: Økonomisk vækst, miljø og transport. Da politisk ledelse kun eksisterer på statsligt og på kommunalt niveau, skal det bemærkes, at det er staten, der med TE-centraler har etableret 15 store regionale forvaltninger. Dvs. den finske stat har skabt nye muligheder for at kunne følge ud- 
viklingen på de regionale markeder for voksen- og efteruddannelse og kompetenceudvikling og vil kunne regulere i tilfælde af "market failure“ (Rubenson 2006).

Finland har p.t. 342 kommuner, og det forventes, at der snart kommer sammenlægninger på det kommunale niveau. Også uddannelsesinstitutioner lægges sammen for at opnå en større „kritisk masse.“ Det gælder f.eks. for universiteter og for erhvervshøjskoler. Landet har tradition for en omfattende langtidsplanlægning, og dette gælder også brugen af de regionale EU-midler (ESF). Den nuværende plan, der skal skabe økonomisk vækst i de nordlige regioner, dækker perioden 2007-2013.

Detaljer om den offentlige rådgivning af SME er ikke kendt, men TEcentralernes samspil med virksomhederne antages at bygge på et offentligt/privat samarbejde. Systemet for voksnes læring er efterspørgselsstyret, men der er tegn på, at den finske stat vil regulere mere.

\subsubsection{Islandske modeller}

Samspillet mellem islandske virksomheder og uddannelsesudbydere drejer sig i udpræget grad om de individuelle brugeres behov for voksen- og efteruddannelse og kompetenceudvikling. Islands undervisningsministerium besluttede i 2006 at satse på udvikling af voksenvejledning/karrierevejledning, og siden har Islands Universitet uddannet medarbejdere, der kan løse opgaven på højt niveau. De islandske vejledere er organiseret i en forening, er stærkt involverede i realkompetencevurdering og har et godt omdømme. Rådgivning af virksomheder omtales ikke i den islandske lovgivning (Althingi, 2010), og det synes heller ikke at være noget, som den semioffentlige FA-organisation har en strategi for.

Det er el-branchens efteruddannelsesinstitution samt IDAN, der rådgiver virksomhederne, når det gælder voksen- og efteruddannelse og kompetenceudvikling. Efteruddannelsesinstitutionen IDAN er et resultat af en fusion mellem fire mindre efteruddannelsescentre i 2006, der også var ejet af brancherne, og den skal dække deres behov. El-branchens efteruddannelsesinstitution og IDAN påtager sig at analysere virksomheders kompetencebehov, og finansieringen af analyserne kommer efter det oplyste fra brancherne selv.

Kortlægningen af de islandske virksomheders kompetencebehov betragtes ikke som en offentlig opgave, og samspillet mellem den rådgivende 
uddannelsesinstitution og virksomhederne må derfor være en relation mellem to organisationer af privat karakter.

Det nationale system for voksnes læring i Island er efterspørgselsstyret, men staten fik nye muligheder for at regulere samspillet mellem uddannelsesvirksomheder og virksomheder, da Altinget i marts 2010 vedtog lovgivning om voksenuddannelse (Althingi, 2010).

\subsubsection{Norske modeller}

Telhaug, Mediås og Aasen (2004) konkluderede i deres studie, at Norge i løbet af 1990erne var blevet Nordens „anderledesland“, når det gælder styringen af uddannelsessystemet. Det norske system har politiske ledere på det statslige, det regionale og det kommunale niveau, og de regionale forvaltninger arbejder med voksnes og unges læring, mens de kommunale forvaltninger forholder sig til voksnes og børns læring. Fra 2010 er fylkeskommunerne (regionerne) blevet tillagt nye forvaltningsmæssige beføjelser i forhold til fagskolerne, der udbyder erhvervsuddannelser på tertiært niveau, hvilket indebærer, at det er regionerne, der administrerer de statslige bevillinger på området og har ansvar for kompetencepolitikken på „prioriterede samfundsområder“ lokalt, regionalt og nationalt. Fagskoleloven blev vedtaget i 2003.

Lovgivningen sikrer voksne brugeres ret til uddannelse på grundskoleniveau og på ungdomsuddannelseniveau. Den norske lovgivning forudsætter, at voksne brugere integreres i systemerne for grundskole og ungdomsuddannelse i modsætning til den danske lovgivning, der placerer de voksne i et parallelt system.

Begrebet „bedrift“ (virksomhed) benyttes sjældent i norske strategipapirer, hvor "arbeidslivet" er det almindeligste synonym for virksomhederne. I strategipapirerne står der ikke noget konkret om samspillet mellem uddannelsesinstitutioner og virksomheder eller om virksomhedsrådgivning, men det nævnes i Stortingsmelding nr. 44 (Kunnskapsdepartementet 2009a), at Nærings- og handelsdepartementet i samarbejde med Kunnskapsdepartementet vil vurdere tiltag, der kan styrke SME i forhold til kompetenceudvikling. Det oplyses desuden, at Norge vil oprette et nationalt system for kortlægning, analyser og dialog om fremtidige kompetencebehov. Dette system vil arbejde i tilslutning til de regionale analyser, som regionerne vil få myndighed til at udføre. 
Vox, Utdanningsdirektoratets fagorgan, vurderes at være den vigtigste offentlige rådgiver for virksomheder, og BKA-programmet, der giver Vox mulighed for at yde medfinansiering i forbindelse med kortuddannedes kompetenceudvikling, spiller antagelig en afgørende rolle for samspillet mellem norske uddannelsesinstitutioner og virksomheder. Medfinansieringen fra Vox medfører, at samspillet i forbindelse med BKA-programmet involverer tre parter: Uddannelsesinstitutionen, virksomheden og staten.

\subsubsection{Svenske modeller}

Begreberne "foretag“ (virksomhed) og virksomhedsrådgivning er sjældne i svenske policy papers om voksen- og efteruddannelse og kompetenceudvikling. Man kan imidlertid finde tekster, der omtaler „næringslivets“ behov og arbejdsmarkedets behov. Dvs. kompetencepolitik er tænkt sammen med erhvervspolitik og beskæftigelsespolitik. Uanset disse tekster antages det, at de lokale uddannelsesinstitutioner i praksis giver de individuelle brugeres behov førsteprioritet.

I et studie af uddannelsesinstitutionernes netværksdannelse i Ørebro Len (Jakobsson 2007) fandt forfatteren ingen tegn på et konkret samarbejde med områdets virksomheder. Det pågældende netværk var på den ene side en succes, fordi det var levedygtigt og kunne fortsætte efter udviklingsbevillingens ophør, og på den anden side var dets resultater begrænsede, når man sætter fokus på dets relationer til arbejdslivet. Netværket forblev et internt anliggende for områdets uddannelsesinstitutioner, og derfor diskuterer det pågældende studie, om „partnerskaber“ inden for voksen- og efteruddannelse og kompetenceudvikling kombineret med en regional styring ville kunne give bedre resultater (Jakobsson 2007).

Da den svenske stat under en arbejdsløshedsperiode overlod statens styring af det lokale udbud af voksen- og efteruddannelse og kompetenceudvikling til de 284 kommuner og ændrede finansieringen til en bloktilskudsmodel, udløste det både økonomisk krise for uddannelsesinstitutionerne og konflikter på personniveau. Det var nu kommunerne, der skulle finde frem til det bedste tilbud blandt de private, de offentlige og de semioffentlige aktører, og det kom til at betyde afskedigelser af voksenundervisere i kommuner som Gøteborg (Carlson 2004). Sveriges overgang til et nationalt marked for voksen- og efteruddannelse og kompetenceudvikling er blevet kaldt en "balkanisering" af uddannelsessystemet (Rubenson et al., 1999). I mange kommuner udbrød der magtkampe, der involverede 
kommunale ledere og politikere, og det kom til at tage lang tid, før der igen var skabt en lokal magtbalance.

Omstillingen indebar, at der opstod lokale modeller på et kontinuum, der strakte sig fra kommuner, der søgte at fastholde et monopol for den lokale offentlige uddannelsesinstitution (Komvux) til kommuner, der kørte Komvux ud på et sidespor; fra kommuner, der betragtede området som en investering til kommuner, der mente, at det var en omkostning osv. Lumsden Wass (2004) arbejder med fire typer af kommuner:

- Den „ikke Komvux-orienterede“ kommune

- Den „ideale“ kommune

- Den markedsstyrede kommune

- Den innovative commune

Reelt er der en mangfoldighed af modeller. Der er imidlertid tegn på, at Sverige vil slække på efterspørgselsstyringen til fordel for offentlig regulering på det nationale niveau kombineret med koordination på det regionale niveau.

En statslig myndighed for de privatiserede arbejdsmarkedsuddannelser blev oprettet i 2008, og Sverige har i 2009 fået en statslig myndighed på erhvervsuddannelsesområdet. Den nye „Yrkeshøgskolemyndighed“ har fået vide beføjelser og bygger på et princip om, at kompetencebehov altid skal dokumenteres. Desuden har regeringen i 2009 pålagt de regionale myndigheder at organisere „regionale kompetensplattforme.“ Dvs. den svenske stat vurderer, at kommunernes og kommuneforbundenes koordination og planlægning er utilstrækkelig: Der er opstået et behov for at udvikle en regional koordinations- og planlægningsfunktion.

Regeringens pålæg fra april 2010 nævner hverken samspil mellem uddannelsesinstitutioner og virksomheder eller virksomhedsrådgivning. Den giver ganske få retningslinjer i sit pålæg, og det må derfor forventes, at regionerne går deres egne veje i implementeringen af pålægget. Regeringen siger dog, at de svenske regioner skal sikre, at der arbejdes med erhvervslivets og arbejdsmarkedets behov på kort sigt og på langt sigt. De individuelle brugeres behov nævnes ikke.

De svenske uddannelsesinstitutioner er fortsat underlagt efterspørgselsstyring, og deres samspil med virksomheder må på det foreliggende grundlag karakteriseres som semi-offentligt/privat. Det svenske system synes at bevæge sig fra kommunalisering mod regionalisering, og staten 
har fået nye myndigheder, der kan regulere markedet for voksen- og efteruddannelse og kompetenceudvikling.

\subsection{Diskussion}

Det har vist sig, at en systematisk indsats for at styrke det lokale samspil mellem uddannelsesinstitutioner og virksomheder, herunder virksomhedsrådgivning er en relativt ukendt strategi på området. En sådan indsats harmonerer imidlertid med de strategier for regulering og koordination af kompetencepolitikken, som er under udvikling i de fleste af landene.

Når flere lande bevæger sig fra kommunal styring mod statslig og regional regulering og koordination, kan det tolkes som en svækkelse af den strategi om at udvikle nationale markeder for voksen- og efteruddannelse og kompetenceudvikling, der blev indført i 1990erne. Det er på det foreliggende grundlag svært at finde argumenter for at vælge den modsatte kurs.

Samspillet mellem udbydere og aftagere i de nordiske lande er noget forenklet illustreret i nedenstående tabel 4.2:

Tabel 4.2 Samspil mellem uddannelsesinstitutioner og virksomheder i de nordiske lande

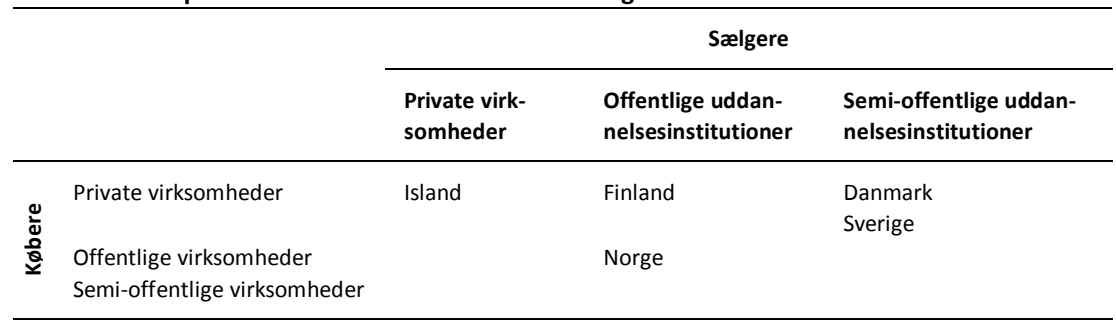

Danmark har gennemført en lovgivning, der gør det muligt at indføre en regional koordination af indsatsen vedrørende voksen- og efteruddannelse og kompetenceudvikling. Når Danmark er det eneste land, der lovgiver på dette område, skyldes det formodentlig, at lovgivning er det mest effektive, når staten ønsker at ændre vilkårene for semi-offentlige uddannelsesinstitutioner. Denne lovgivning svækker samtidig mulighederne for at fastholde en national strategi, der bygger på efterspørgselsstyring. Beslutningen om at indføre systematisk virksomhedsrådgivning må derfor antages at være en supplerende foranstaltning, der tages i anvendelse, fordi den danske stat opgiver tænkningen i et nationalt marked for voksen- og efteruddannelse og kompetenceudvikling. 
Finland og Danmark har afskaffet politisk ledelse på det regionale niveau og har derfor behov for at sikre, at der koordineres på dette niveau. Finland vælger at lade staten udfylde tomrummet ved hjælp af TEcentralerne, mens Danmark pålægger sine semi-offentlige uddannelsesinstitutioner at udvikle en ny koordinationsfunktion, der kan varetages af VEU-centre. Begge ændringer har været i kraft siden den 1. januar 2010, og det er derfor ikke muligt at sige noget om effekten af de nye foranstaltninger og om hvorvidt de vil kunne understøtte det lokale samspil mellem uddannelsesvirksomheder og virksomheder.

Den norske BKA-model er blevet permanent. Der er gjort gode erfaringer med det samspil mellem uddannelsesinstitutioner og virksomheder, der udspringer af den medierende virksomhed, som staten (via Vox) udøver. Modellen har interesse, fordi antallet af voksne brugere er stort, og fordi den bygger på en virksomhedsrådgivning, der ydes af Vox. Der er tre parter i samspillet, og det vurderes at være en kvalitet, der gør, at dette studie betragter BKA-modellen som god nordisk praksis. Formodentlig arbejder FA i Island som samme måde.

De svenske regionale „kompetensplattforme“ vil formodentlig kunne understøtte samspillet mellem uddannelsesinstitutioner og virksomheder og måske også sikre adgang til virksomhedsrådgivning. Der er imidlertid tale om en ny offentlig foranstaltning - i lighed med de danske VEU-centre og de finske TE-centraler - og derfor er der ikke basis for en vurdering af strategiens effektivitet.

\subsection{Delkonklusion med anbefalinger}

De fem nordiske lande scorer højt, når det drejer sig om voksnes deltagelse i voksen- og efteruddannelse og kompetenceudvikling. Det er en succeshistorie, men måske er nogle nationale strategier ved at være gamle, og det vurderes derfor at være fremsynet, hvis de nationale strategier for kompetenceudvikling justeres for at sikre, at de er effektive i forhold til den hastige omdannelse af samfundet. Landene har allerede besluttet at give staten bedre muligheder for at regulere, og de fleste af dem lægger desuden vægt på, at der koordineres på det regionale niveau.

Tænkningen i nationale markeder for voksen- og efteruddannelse og kompetenceudvikling synes at være svækket, mens mulighederne for offentlig regulering og regional koordination synes at være styrket. Denne 
omstilling vil formodentlig kunne give det lokale samspil mellem uddannelsesinstitutioner og virksomheder bedre vilkår og desuden bidrage til anvendelsen af systematisk virksomhedsrådgivning.

På baggrund af analysen af samspillet mellem uddannelsesinstitutioner og virksomheder anbefales det at:

- Der iværksættes komparative studier af regional regulering og koordination af voksen- og efteruddannelse og kompetenceudvikling

- De nordiske lande diskuterer relevansen af et fælles udviklingsprojekt om anvendelsen af virksomhedsrådgivning i det lokale samspil mellem uddannelsesinstitution og virksomhed

- Der igangsættes undersøgelser af, hvorledes rådgivning af en SME, som ydes af offentlige og semi-offentlige uddannelsesinstitutioner, kan gøres mere effektiv

- Der igangsættes analyser af, hvorvidt partnerskaber (langsigtede samarbejdsrelationer) er mere relevante og effektive end kortsigtede projekter på rene markedsvilkår, herunder hvilken rolle mulighederne for offentlig medfinansiering spiller

- Det undersøges, hvem virksomhedsrådgiverne er, herunder rådgivernes faglige profil, løn- og ansættelsesvilkår, samt hvordan de betragter deres opgaver

- Der igangsættes analyser af, hvorvidt modeller som den danske og den finske model, hvor semi-offentlige uddannelsesinstitutioner har ansvar for koordination, er effektive i forhold til samspillet mellem uddannelsesinstitutioner og virksomheder 


\section{Vuxnas nyckelkompetenser}

\subsection{Introduktion}

Huruvida det går att identifiera specifika nyckelkompetenser, nödvändiga för individers möjligheter att hantera utmaningar i dagens samhälle och arbetsliv har engagerat de internationella organisationerna OECD och EU. Båda organisationerna har också diskuterat hur sådana nyckelkompetenser skulle kunna formuleras. Nyckelkompetenser berör framför allt grundläggande aspekter av vad som krävs för att leva i dagens samhälle, och för att kunna klara ett arbete. Resonemangen knyter inte bara an till vuxna, utan även till barn och unga. Båda organisationerna har också ambitioner att påverka medlemsländernas utbildningspolitik genom rekommendationer, så kallad mjuk normgivning, om än med olika medel. Kerstin Jacobsson \& Niklas Noaksson (2006) använder uttrycken "expertorganisationen" respektive "den politiska organisationen" för att belysa en grundläggande skillnad mellan organisationerna, betraktat som idealtyper. De pekar bl a på att "OECD:s största tillgång är att det är en expertorganisation som producerar vetande", samt vidare att "OECD har en unik analyskapacitet att göra studier i ett jämförande perspektiv" (Ibid. s. 51). EU är, som vi vet, en politisk union. Frågan om nyckelkompetenser kan knytas till såväl utbildnings- som arbetsmarknadspolitik, två politikområden som emellertid bygger på nationell beslutsmakt. Samtidigt finns ett politiskt samarbete mellan medlemsländerna som påverkar EU:s rekommendationer och som kräver förhandling mellan skilda intressen. Jacobsson \& Noaksson (2006) menar att "till skillnad från OECD är inte EU:s primära roll är att producera vetande utan att skapa politiska handlingsprogram. Underlag tas fram för att motivera behovet av policies och för att övertyga politiska aktörer" (Ibid. s. 54). OECD:s legitimeringsgrund är med andra ord expertkunskapen och EU:s är gemensamma politiska mål, värden och intressen (Ibid. s. 73).

I det följande presenteras helt kort OECD:s respektive EU:s arbete med nyckelkompetenser. 


\subsubsection{OECD:s nyckelkompetenser}

OECDs projekt "Definition and Selection of Competencies: Theoretical and Conceptual Foundations" (DeSeCo), initierades 1997 och leddes av schweiziskan Dominique Simone Rychen. Projektet hade som inriktning att utveckla den teoretiska och begreppsliga grunden för nyckelkompetenser (Rychen \& Tiana 2004).

Människors lika möjligheter, liksom respekten för mänskliga rättigheter och fred framställs i projektets redovisning som mycket angelägna, och tillika oerhört komplexa, problemområden att komma tillrätta med. Det handlar å den ena sidan om människors grundläggande rätt till utbildning, och å den andra sidan om att läroplansbaserade och ämnesrelaterade kunskaper inte ensamt ger den slags utbildning som är relevant för utveckling. Projektet ger uttryck för en stark tilltro till utbildning som en samhällsförändrande kraft. Man ser emellertid inte enbart utbildning i institutionaliserad skolform som tillräcklig för uppnående av nyckelkompetenser, utan betonar även deltagande i arbets- och samhällsliv (Rychen \& Tiana 2004). Människors intellektuella förmågor betraktas inte som något isolerat och välavgränsat, utan som inflätade i sociala och kulturella sammanhang. Praktiskt handlag, samt svårfångade aspekter som attityder, känslor, värden, etik och drivkrafter, framhålls som viktiga, dvs allt en människa gör och är. Nyckelkompetenser beskrivs som en tredelad helhet:

"The focus on acting autonomously is on relative autonomy and identity. Using tools interactively is about an individual's interaction with the world through physical and socio-cultural tools /.../ functioning in socially heterogeneous groups emphasizes the individual's interaction with the other, the different other" (Rychen, 2004: 23).

Uppmärksamheten riktas såväl mot personlig utveckling som mot en grund för yrkesverksamhet. Ambitionerna är med andra ord mycket höga och arbetet är mycket omfattande och ambitiöst upplagt. Nyckelkompetenser i OECD:s version handlar emellertid om förmågor som är svårfångade, och därför inte helt okomplicerade att överföra till utbildningsprogram, eller ens till nationella utbildningssystem, annat än som inriktningsformuleringar, dvs något man möjligen uppnår genom viss utbildning med viss kvalitet. I policysammanhang kan detta syfte emellertid ha ett betydande värde och kan beröra människors förmåga och möjlighet att leva ett gott liv.

Konkretion uppnås bl a genom att nyckelkompetenser operationaliseras och görs mätbara vilket samtidigt ger uttryck för en mycket instru- 
mentell syn på frågan. Sådana mätningar rör ofta, på olika sätt, förmågan att kunna läsa, skriva och räkna samt problemlösning. En uttalad målsättning är att DeSeCo-programmet ska kunna formulera indikatorer och därmed ligga till grund för utveckling av internationella jämförelser, policystrategier för stärkandet av nyckelkompetenser samt utvärderingar (OECD 2005; Rychen \& Salganik 2003):

"Emphasis put on evaluation of skills and competencies derives from the awareness that transmitting knowledge is not enough if education has to respond to the growing demands it faces" (Tiana 2004, s. 52).

Befolkningars kompetens och hur denna ska kunna formas har under de senaste decennierna också kommit att bli en fråga om mätningar och internationella jämförelser (Tiana 2004, s. 37-38; Tuijnman, 1997).

Exempel på internationella jämförelser avseende den vuxna befolkningens kunskaper och kompetens, och som föregick DeSeCo:s arbete, var International Adult Literacy Survey (IALS) respektive Adult Literacy and Lifeskills Survey (ALL). IALS mätte läsförmåga samt förmågan att tolka dokument och att utföra beräkningar. Danmark, Finland, Norge och Sverige deltog i denna undersökning år 1998. Sverige deltog även år 1994. I tillägg till IALS, mätte ALL räkneförmåga, analytisk förmåga, samarbetsförmåga och förmåga att använda IT. Norge deltog i undersökningen år 2003.

OECD samordnar för närvarande en pågående undersökning av vuxna som kallas PIAAC (Programme for the International Assessment of Adult Competences) och som kommer att rapporteras år 2013. Danmark har för detta ändamål inrättat det statligt finansierade "Danskernes Kompetencer" (www.danskerneskompetencer.dk). I Sverige är det Statistiska centralbyrån som genomför undersökningen (www.scb.se). Även Finland (www.minedu.fi) och Norge (www.regjeringen.no) deltar. PIAAC undersöker vuxnas förmåga att lösa olika uppgifter som de stöter på hemma och i arbetet: hur läs- och matematikkunskaper används, hur information söks samt hur dator eller andra tekniska hjälpmedel används för att lösa olika former av problem. Avsikten är att de medverkande länderna ska använda undersökningen för att utveckla utbildningsinsatser (www.oecd.org; www.scb.se). 


\subsubsection{EU:s nyckelkompetenser}

EU antog år 2006 ett förslag om "Rekommendationer för nyckelkompetenser inom området livslångt lärande" och Lissabonstrategin från 2000 var utgångspunkten (EU 2006). Lissabonstrategin hade som mål att fram till år 2010 göra Europa till världens mest konkurrenskraftiga, dynamiska och kunskapsbaserade ekonomi. Bland annat identifierades nya, (här i engelskspråkig version p.g.a. att översättningen kan variera mellan de nordiska länderna): "basic skills for a knowledge-based economy: ICT, technological culture, entrepreneurship, foreign languages, and social skills" (European Commission 2004, s.1).

Till Lissabonstrategin fogas "Detaljerat arbetsprogram för uppföljningen av målen för utbildningssystemen i Europa" (EUT C142/2002) och som i Sverige kommit att benämnas "Utbildning 2010." Utbildning 2010 diskuterar bland annat frågan om kompetenser som alla bör förvärva. Arbetet mynnar ut i rekommendationerna om nyckelkompetenser år 2006. EU anger också "ett engagemang för mätbara förbättringar" avseende "läsförmåga, avbruten skolgång, antalet elever som avslutar gymnasieutbildning och vuxnas deltagande i livslångt lärande" samt konstaterar en nära anknytning till utvecklingen av nyckelkompetenser rörande dessa aspekter (EU 2006, punkt 5).

Lissabonstrategin löper ut vid årsskiftet 2010/2011 och ersätts därefter med "Europa 2020: En ny europeisk strategi för sysselsättning och tillväxt" (Europeiska rådet 2010). Europa 2020 lyfter fram sysselsättningsfrågan, betydelsen av att människor fullföljer sina gymnasiestudier och att fler går vidare till högre utbildning. Andra framträdande målområden är forskning och utveckling, klimat/energi samt fattigdomsbekämpning. Begreppet nyckelkompetens används även i Europa 2020, där man framhåller att nationella reformer inom området utbildning och fortbildning bör syfta till att:

\footnotetext{
"Ensure the acquisition of the key competencies that every individual needs for success in a knowledge-based economy, notably in terms of employability, further learning, or ICT skills" (EU 2010, s.22).
}

EU:s rekommendationer om nyckelkompetenser från år 2006 riktas mot ungdomars grundläggande utbildning, men också mot vuxnas lärande. Rekommendationerna bygger delvis på OECD:s arbete (Liedman 2008; 
Mark 2009). En ambition som uttrycks är att rekommendationerna ska underlätta läroplansreformer.

EU:s åtta nyckelkompetenser är:

- Kommunikation på modersmålet

- Kommunikation på främmande språk

- Matematiskt kunnande och grundläggande vetenskaplig och teknisk kompetens

- Digital kompetens

- Lära att lära

- Social och medborgerlig kompetens

- Initiativförmåga och företagaranda

- Kulturell medvetenhet och kulturella uttrycksformer

Inte heller EU:s nyckelkompetenser är direkt gripbara företeelser, som på något enkelt sätt kan omsättas och operationaliseras till nationella utbildningssystem och utbildningssatsningar. Här finns en vaghet, mångtydighet och formbarhet som paradoxalt nog kan göra det lätt att passa in dem i befintliga nationella sammanhang.

OECD:s respektive EU:s resonemang om nyckelkompetenser handlar inte enbart om vuxnas lärande, utan även om barns och ungas lärande, i och utanför formella skolsystem (se $t$ ex Carlgren, Forsberg \& Lindberg 2009 för en genomgång av den svenska skolans kunskapsdiskussion). Nyckelkompetenser berör samtliga examina och är inte knutet till ålder. När det specifikt gäller vuxnas utbildning och lärande har diskussionen inte varit särskilt framträdande i de nordiska länderna, inte heller finns en tydligt framträdande nordisk forskningsdebatt i frågan.

Floran av begrepp som knyter an till begreppet nyckelkompetenser är omfattande. Vi har till exempel att göra med kompetens, kvalifikation, attityd, färdighet, kunskap. Avsikten i detta arbete är inte att diskutera den kunskapssyn som ligger till grund för användandet av de olika begreppen. Vi lämnar istället frågan om kunskapssyn öppen. Det finns emellertid en tydlig vinkling i EU:s respektive OECD:s resonemang som kan vara värd att framhålla. Kompetens framställs som något kvantifierbart, och det görs också mätningar regelbundet. Därmed finns en risk att kompetenser som är svåra att kvantifiera ges liten vikt vid förverkligande av organiserade lärsituationer, även om kompetenserna är värdefulla för individer och samhälle. Det som kanske är det mest viktiga kan falla bort 
om det handlar om något som inte är enkelt att mäta. Utfallet kan då bli tvärtemot det önskade. Skolan har en uppgift att föra ett samhälls- och kulturarv vidare. Det måste också ses som allas rätt att få ta del av detta, även vuxna, vilket också betyder att en sådan kunskap inte alltid behöver vara nyttig i något specifikt avseende.

\subsection{Nyckelkompetenser i de nordiska länderna}

Följande utgör underlag för att beskriva de fem nordiska ländernas insatser för att stärka vuxnas nyckelkompetens i förhållande till deltagande på arbetsmarknad och i samhällsliv:

- År 2009 besvarade bland andra de fem nordiska länderna ett frågeformulär från EU angående progression och implementering av "Key competences for lifelong learning as part of coherent and comprehensive lifelong learning strategies." Frågorna knyter an till implementering av programmet Utbildning 2010. Det är EU:s nyckelkompetenser som står i centrum och svaren från de nordiska länderna berör hela utbildningsområdet, från obligatorisk skolgång till strategier för vuxenutbildning

- Relevanta utvärderingar och projektbeskrivningar (Finland och Norge)

Satsningarna i de nordiska länderna kan med utgångspunkt rapporteringen till EU genomföras som:

- Integrerat i statliga läroplaner och därmed knutna till formell utbildning

- Integrerat i annan utbildningsverksamhet utan att bygga på en statlig läroplan

- I tid avgränsade projekt

Satsningarna kan därmed antingen vara en fråga för det formella utbildningssystemet, för andra organisationer eller knytas till det lärande som sker på enskilda arbetsplatser. 


\subsubsection{Danmark}

\section{Integrerat i läroplaner}

I rapporten till EU svarar Danmark att de nationella läroplanerna genomsyras av rekommendationerna om nyckelkompetenser.

\section{Integrerat $\mathbf{i}$ annan utbildningsverksamhet}

I svaren på detta projekts frågeformulär betonas starkt betydelsen av arbetskraftens grundläggande och generella färdigheter. Det är framförallt kortutbildade vuxna som ska delta i kort allmänt inriktad utbildning. Man vill från danska statens sida öka möjligheterna att kombinera kurser i läsa, skriva och räkna med yrkesutbildningar för vuxna. Utbildning av detta slag ska kunna ske i samverkan mellan utbildningsanordnare och arbetsplatser. Arbetsmarknadens parter är involverade, även på lokal nivå. Det är arbetslivets behov av utbildning man framhåller. Utbildningen finansieras av extra medel från staten och undervisningsministeriet är ytterst ansvarigt. De olika utbildningsanordnarna är ansvariga för att möta den lokala arbetsmarknadens behov av utbildning men är dock relativt självständiga. Danmark framhåller även att den nationella satsningen utvecklades innan EU:s rekommendationer om nyckelkompetenser lanserades.

I rapporteringen till EU omnämns även en nationell handlingsplan angående en strukturell uppbyggnad av mycket korta IT-kurser (2-5 dagar) med totalt 25 olika program, likaså en handlingsplan som kombinerar yrkesutbildningskurser för vuxna med kurser i att läsa, räkna och skriva.

\section{Specifika projekt}

Åren 2006 och 2007 genomfördes ett nationellt projekt, delvis finansierat av Europeiska socialfonden, där 15 kompetenscentra för yrkesutbildning för vuxna etablerades. Kurser i att läsa, räkna och skriva kombinerades med yrkeskurser. Syftet var att öka attraktiviteten vad gäller yrkesutbildning för vuxna samt göra den mer fokuserad och flexibel relativt individens och företagets behov.

\subsubsection{Finland}

\section{Integrerat i läroplaner}

Finland svarar i sin rapport till EU att nyckelkompetenser för livslångt lärande är en del av de nationella läroplanerna för grundläggande och gymnasial utbildning. Nyckelkompetenser formar också delar av de stu- 
dier i allmänna ämnen som hör till kraven på yrkeskompetens. De nationella läroplanerna antogs före det att EU presenterade sina rekommendationer om nyckelkompetenser.

I enkätformuläret ställs frågan om samverkan med företag. I Finlands svar betonas särskilt företagaranda, något som är en del av all yrkesutbildning och implicit även i all annan utbildning, på alla nivåer.

\section{Integrerat $\mathrm{i}$ annan utbildningsverksamhet}

Ungefär hälften av den offentligt finansierade utbildningen för vuxna ges av utbildningsinstitut för fritt bildningsarbete. Dessa väljer själva innehållet i den utbildning de erbjuder, men i överenskommelse med undervisningsministeriet och de aktuella utbildningsanordnarna ska vissa områden vara prioriterade. Särskilt betonas språk och IT men även andra aspekter finns med. I rapporten till EU anges följande fem prioriterade områden som sägs svara för ungefär $10 \%$ av tiden i klassrummet:

1. Language and cultural education and other integration-promoting studies for immigrants

2. Studies enhancing citizenship skills and civil society skills

3. Information society skills

4. Health-promoting studies

5. Education preparing for open university studies

År 2007 införde Utbildningsministeriet ett voucherprogram till denna typ av utbildningsanordnare för att stödja och utveckla utbildning för specificerade målgrupper. Målgrupperna är invandrare, arbetslösa, pensionärer och äldre, personer med specialpedagogiska behov samt personer som saknar utbildning utöver den obligatoriska.

Det särskilda organet Rådet för livslångt lärande arbetar bland annat med att främja samverkan mellan utbildning och arbetsliv och i rapporten till EU anges att en av dess arbetsuppgifter är frågan om nyckelkompetenser.

\section{Specifika projekt}

Mellan åren 2003 och 2009 pågick det så kallade NOSTE programmet där vuxna mellan 30 och 59 år erbjöds yrkesinriktade kurser av olika slag eller datakört/delar därav. Det vanligaste området var datakörkort (42 \%).

Programmet initierades av Utbildningsministeriet tillsammans med Arbetsmarknadsministeriet, i överenskommelse med de politiska partierna och arbetsmarknadens parter. Syftet var dels att förbättra karriärmöjligheter och 
arbetstillfredsställelse bland personer som enbart hade grundläggande utbildning, och dels att motverka arbetskraftsbrist på grund av stora pensionsavgångar. Tanken var att stimulera till fortsatta studier. Målgruppen beräknades till 350.000 personer och ca 25.700 personer kom att delta, dvs 7,3\% av målgruppen. Målet var satt till $10 \%$ av målgruppen. Könsfördelningen var relativt jämn med 53 \% kvinnor och 47 \% män. Programmet finansierades av staten som avsatte 124,5 miljoner Euro. Programmet var utan kostnad för kursdeltagare och arbetsgivare. Det drevs i projektform och inkluderade sammantaget 59 projekt. Sammanlagt 600 partners var engagerade, såsom yrkesinstitut, vuxenutbildningscentra, folkhögskolor, gymnasieskolor, lärlingsutbildningscentra, fackförbund och jobbcentra. Programmet genomfördes nära arbetsplatser och tog stor hänsyn till arbetslivets behov (http://www.noste-ohjelma.fi/fin/bitmap.asp?R=1171).

En utvärdering (Hulkari \& Paloniemi 2008) pekade bl.a. på målgruppens heterogenitet där aspekter som personlig bakgrund, ålder, erfarenheter, motivation, förmåga att lära och behov av stöd kunde skilja sig avsevärt. Utvärderingen pekade vidare på att många uttryckte ett ökat intresse för studier som ett resultat av deltagande i programmet, likaså att man mer allmänt mådde bättre på jobbet.

Utvärderingen var också kritisk och pekade på svårigheterna vad gällde samverkan mellan olika verksamheter, trots de resurser som sattes in. Programmet startade långsammare än förväntat vilket tros kan ha berott på projektens strategiska inriktning relativt de medverkande verksamheternas egna intressen. Arbete i nätverk tog mycket tid i anspråk när det gällde att överbrygga konkurrens och motstridiga ambitioner bland partnergrupperna. Utvärderaren konstaterade att utbildningsinstitutioner inte styrdes enbart efter NOSTE programmets principer utan också efter egna institutionella regler och utbildningsområdets marknadsekonomi. Det varierade hur väl projektet passade in och hur strategiskt viktigt projektet ansågs vara, i förhållande till den egna verksamheten. Även projektledarnas kompetens var många gånger avgörande, likaså det stöd som gavs från utbildningsorganisationerna. Resurserna kom heller inte alltid att användas som de var avsedda.

En rekommendation från utvärderarna var att alla involverade i projekten behövde utbildas innan projekten drogs igång, så att de bättre kunde uppmärksamma de äldres behov. 


\subsubsection{Island}

\section{Integrerat i läroplaner}

Island pekar i sin rapport till EU på ett pågående arbete med revidering av de nationella läroplanerna på samtliga skolnivåer och att dessa kommer att grundas på EU:s rekommendationer om åtta nyckelkompetenser. Den nya vuxenutbildningslagen inkluderar brobygge mellan validering av reell kompetens och det formella utbildningssystemet.

\section{Integrerat $\mathrm{i}$ annan utbildningsverksamhet}

I samverkan mellan arbetsgivar- respektive arbetstagarorganisationer har särskilda fonder skapats för utbildning av anställda. Målgruppen är vuxna i avsaknad av gymnasieutbildning. Andelen vuxna som saknar formell utbildning utöver grundläggande nivå är cirka $35 \%$ av befolkningen, vilket den isländska staten anser vara alldeles för högt. Målet är att denna siffra ska ha sjunkit till $10 \%$ år 2020 .

\section{Specifika projekt}

I rapporten till EU anges att ett antal projekt har initierats med syftet att identifiera personer som i förtid har hoppat av från yrkesutbildning, att validera deras yrkeskunskaper och att hitta vägar för dem att kunna avsluta studierna. Dessa projekt beskrivs dock inte närmare.

\subsubsection{Norge}

\section{Integrerat i läroplaner}

Norge anger i rapporten till EU att frågan om nyckelkompetenser är integrerad i de nationella läroplanerna.

I det norska utbildningssystemet har särskild uppmärksamhet ägnats åt frågan om baskompetenser genom den så kallade Kunnskapsløftet, något som också särskilt lyfts fram i rapporten. Baskompetenserna innefattar att kunna uttrycka sig muntligt, att kunna läsa, räkna och skriva samt att kunna använda digitala redskap. De är integrerade i läroplanerna från skolans årskurs 1, som en del av alla skolämnen men utan att vara ämnesberoende. Nationella test har utvecklats som mäter uppnående av de grundläggande färdigheterna (att kunna läsa norska och engelska samt att kunna räkna). Resultaten av testen publiceras offentligt på kommunal, 
regional och nationell nivå. Rapporten till EU pekar på att frågan om baskompetenser även är giltig för vuxna.

\section{Integrerat $\mathrm{i}$ annan utbildningsverksamhet}

Det har beräknats att omkring 430000 vuxna norrmän har så låga kunskaper när det gäller språket att de kan få problem i framtidens arbetsliv. Beräkningen grundas på resultatet av Norges deltagande år 2003 i OECD:s internationella undersökning ALL (Adult Literacy and Life Skills). Norge rankades lågt när det gällde vuxnas förståelse av tal och skrift. Många av de lågt rankade hade arbete, men ansågs att vid eventuell arbetslöshet kunna få svårt att hitta ett nytt jobb. Särskilda grupper som pekas ut är vuxna som inte har fullföljd utbildning på grund- och gymnasial nivå, vuxna som har svårigheter när det gäller att läsa, skriva och räkna, vuxna som saknar digital kompetens, flyktingar och invandrare samt arbetslösa i avsaknad av grundläggande färdigheter (http://www.vox.no).

Vox, det nationella organ som inrättades år 2001 som en följd av kompetensreformen, har ett särskilt uppdrag när det gäller frågan om vuxnas grundläggande färdigheter (www.vox.no). Det nationsövergripande "Program for basiskompetanse i arbeidslivet" (BKA), som startade år 2006, organiseras genom Vox, på uppdrag av Kunskapsdepartementet.

\section{Specifika projekt}

BKA utlyser statliga medel för projekt rörande grundläggande färdigheter i att läsa, skriva, räkna och datakunskap. Privata och offentliga verksamheter samt andra organisationer från hela landet kan söka. Utbildningsorganisationer kan också söka i samarbete med en eller flera verksamheter. Medverkande företag måste delfinansiera det aktuella beviljade projektet. En bärande idé är alltså att ge ekonomiskt stöd till arbetsgivare som vill utveckla sina anställda. Stödet ses som ett incitament till företag och utbildningsanordnare att satsa på den grupp som anses behöva utveckla kunskaper i läsa, skriva och räkna samt i datakunskap. I samverkan med lärarutbildningen har en kurs utformats som är inriktad mot lärare som undervisar i grundläggande färdigheter för vuxna. Kursen ger lärarna formella utbildningsmeriter.

Målet med BKA är att inga vuxna ska vara utestängda från arbetslivet på grund av att de saknar grundläggande färdigheter. Genomgången utbildning ger inga formella kursbevis. Huvuddelen av deltagarna är anställda, endast en mindre andel är arbetslösa. 
Nedanstående tabell 5.1 ger en överblick över BKA-programmets omfattning. Tabellen visar också på det ökande intresset samt att programmet successivt har utökats:

Tabell 5.1 Vox, antal projekt och medel.

\begin{tabular}{lrrrr}
\hline År & $\begin{array}{c}\text { Antal sökande } \\
\text { verksamheter }\end{array}$ & Antal tilldelade & $\begin{array}{r}\text { Sökt belopp mill. } \\
\text { NOK }\end{array}$ & $\begin{array}{r}\text { Tilldelat belopp mill. } \\
\text { NOK }\end{array}$ \\
\hline 2010 & 343 & 204 & 168 & 78 \\
2009 & 270 & 162 & 122 & 56 \\
2008 & 279 & 96 & 119,5 & 30 \\
2007 & 70 & 78,2 & 20 \\
2006 & 167 & 65 & 85,5 & 14,5 \\
\hline
\end{tabular}

Källa: http://www.vox.no

Ett exempel på ett projekt inom BKA-programmet är det som kom att kallas "Nya möjligheter" och som innebär ett samarbete mellan Vox, Opplæringskontoret for teknologifag i Agder, och en utbildningsanordnare. Förutom kursdeltagarna rekryterades ett antal företag till projektet. Projektet skulle motivera och rekrytera unga vuxna med avbruten ungdomsutbildning. Målet var att de skulle få arbete eller gå vidare till fortsatt utbildning. Utgångspunkten för projektet var Vox kompetensmål i läsning, skrivning och vardagsmatematik, men hela tiden i kombination med yrkesrelevans. Det handlade om utbildning som grundades i arbete och det var de mest svaga vad gällde utbildning och möjligheter att få arbete som skulle rekryteras. Målgruppen fick själva anmäla sitt intresse för projektet och deltagarna valdes sedan ut genom ett intervjuförfarande där intresse och motivation kartlades. Totalt 32 personer hade anmält sitt intresse för deltagande och totalt nio kunde starta (Byholt 2009).

Av projektets rapport framgick att utöver frågan om läsa, skriva och räkna var gränssättande instruktörer ett viktigt inslag. Projektet handlade inte enbart om att deltagarna skulle lära sig välavgränsade, diskreta kunskaper, utan även om att fungera och att handla kompetent i utbildning och i arbetsliv samt om social och kommunikativ kompetens. Eftersom antalet deltagare var få möjliggjordes nära kontakter mellan utbildare och deltagare. (Byholt 2009).

Konsultföretaget ECON genomför utvärderingar av BKA på uppdrag av Kunskapsdepartementet. I rapporten som avser år 2006 skriver ECON (2007) att motivet för verksamheternas medverkan är att utbildningen ska leda till att de anställda bättre klarar sitt arbete. Främst efterfrågas utbildning i datakunskap. 
Utvärderingen pekar på problem där medel tilldelas projekt i konkurrensurval (ECON 2007). Alla är till exempel inte lika bra på att skriva ansökningar, och många små- och medelstora företagare kan ha lika svårt med baskunskaperna som de anställda. Det är inte givet att det finns en välutbildad stab att tillgå för att formulera en ansökan. Därmed finns en risk att stora grupper ställs utanför om projekten utgår från enskilda verksamheters ansökningar.

I utvärderingen framkommer också problem med att betrakta gruppen kortutbildad som enhetlig. Problematiken med bristande baskompetenser behöver inte heller sammanfalla med utbildningsnivå. En person med längre utbildning kan ha svårigheter och en person med kort utbildning kan ha mycket goda baskunskaper. För många vuxna kan det också kännas stigmatiserande att bli uttagen av sin arbetsgivare till att gå en kurs med inriktning mot att lära sig läsa, skriva och räkna. ECON framhåller vikten av rätt kompetens bland de lärare som utbildar vuxna i frågan (ECON 2007).

Mot bakgrund av det stora intresset för datakunskap diskuterar utvärderingsrapporten verksamheternas efterfrågan relativt BKA:s mål och prioriteringar. BKA riskerar, menar ECON, att stödja ett område där viljan till finansiering redan är hög och utbildningssatsningen troligen skulle ha genomförts ändå, oavsett ekonomisk stöd. Utbildning i att läsa, skriva och räkna riskerar att inte bli genomförd. ECON menar å ena sidan att det är mot det senare området som projekten bör inriktas. Å andra sidan kan datakunskap upplevas som mindre stigmatiserande för den enskilde kursdeltagaren och datakurser kan även stimulera till andra studier. ECON framhåller dock att strategin att gå vägen via datakursen är mer osäker och kräver en mycket genomtänkt uppläggning (ECON 2007).

\subsubsection{Sverige}

\section{Integrerat i läroplaner}

I rapporten till EU svarar Sverige att nyckelkompetenser är integrerat i de nationella läroplanerna. De läroplaner texten refererar till utformades redan 1994. Rapporten framhåller även folkbildningens betydelse när det gäller nyckelkompetenser. Här kan nämnas att en ny läroplan för gymnasieskolan introduceras hösten 2011. Inom vuxenutbildningen införs den hösten 2012. 
Utgångspunkten för all vuxenutbildning är individens behov av utbildning. De grupper som anses utbildningsmässigt svaga prioriteras vid antagning. Ambitionen är också att bereda för samverkan i olika former när det gäller frågan om vuxenutbildning. Samverkan mellan utbildningsanordnare, branscher, arbetsmarknadens parter ska ske på lokal kommunal nivå samt mellan politikområden på nationell nivå. Genom så kallade regionala kompetensplattformar, inrättade år 2010, ska samverkan uppnås på regional nivå.

Den svenske idéhistorikern Sven-Eric Liedman (2008) har på Skolverkets uppdrag granskat den statliga läroplanen från år 1994 angående frågan om EU:s nyckelkompetenser. Liedman menar att EU:s skrivning om nyckelkompetenser innehåller många oklarheter, bl a hur begreppet nyckelkompetens ska tolkas: "Dokumentets oklara punkter gör det inte lätt att omedelbart relatera det i förhållande till de gällande styrdokumenten för den svenska skolan Lpo 94 och Lpf 94. Tydligt är dock att de gällande styrdokumenten långt mer betonar lärandet som en sammanhängande bildningsprocess där reflektion och kritiska ställningstaganden spelar en stor roll, medan EU-dokumentet snarare betonar kunskapen som en fråga om god och ändamålsenlig teknik" (Liedman 2008, s3). Liedman betonar alltså att de svenska styrdokumenten från år 1994 går längre i sina ambitioner att betona lärandet som en bildningsprocess än vad EUdokumentet gör.

\subsection{Diskussion}

Begreppet nyckelkompetens är svårfångat och inte alls framträdande $\mathrm{i}$ den nordiska debatten rörande vuxnas lärande. Detta avsnitt bygger främst på de nordiska ländernas rapporter till EU. Dessa texter besvarar specifikt frågor om nyckelkompetenser. Flera länder har också uttryckligen hänvisat till denna rapportering i samband med de frågor som ställts inom detta projekt. I rapporterna är det inte entydigt vad som framstår som utveckling av nyckelkompetenser alternativt utveckling av vuxnas lärande i allmänhet. Därför bör denna text läsas med försiktighet, det finns ju hela tiden en risk att rapporteringar blir policy i sig, en risk som för övrigt gäller alla komparativa studier.

De nordiska länderna bedömer i sina respektive rapporter att EU:s rekommendationer om nyckelkompetenser på olika sätt stämmer väl överens med innehållet i de nationella läroplanerna, trots att läroplanerna i de flesta 
fall har tillkommit före det att rekommendationerna lanserades. EU:s rekommendationer anses av de nordiska länderna som uppfyllda. Det är därför rimligt att anta att EU:s respektive OECD:s skrivningar i frågan om nyckelkompetenser har haft ett litet inflytande i de nordiska länderna. Ett skäl kan vara den långa tradition som finns när det gäller utbildning för vuxna och att läroplanerna är liknande eller samma som dem inom ungdomsskolan. Ett annat skäl kan vara sysselsättningskrisen under 1990-talet och som kom att bli särskilt kännbar för Finland och Sverige. Frågor som berör vuxnas lärande i förhållande till arbetsmarknadssituationen har fått stor politisk uppmärksamhet under de senaste decennierna, inte minst genom att frågan om anställningsbarhet placeras i centrum (se t ex Fejes 2010).

Insatser för att stärka vuxna i grundläggande kommunikativa färdigheter står ofta i fokus när det gäller specifika projekt. De specifika projekten är inriktade mot vad som krävas för att kunna få eller behålla ett arbete. Norge lyfter särskilt fram begreppet baskompetens i sin rapport till EU. BKA-projektet är ett exempel på ett mer omfattande program med statligt stöd och som vänder sig till verksamheter. Projektet gör tydligt hur omfattande problematiken med bristande baskompetenser anses vara. 400.000 personer är många, och antalet har uppskattats med utgångspunkt från resultatet av Norges deltagande i OECD:s undersökning ALL (Adult Literacy and Life Skills). Det finska NOSTE är ett annat exempel på ett mer omfattande projekt med statligt stöd. Utvärderingar av båda dessa projekt pekar på problem av organisatorisk art när det gäller genomförandet, bl a när det gäller samverkan mellan olika slags verksamheter med skilda intressen.

\subsection{Delkonklusion med rekommendationer}

De nordiska länderna anser att EU:s rekommendationer om nyckelkompetenser är integrerad i nationella läroplaner. Läroplanen är statens styrdokument och berör frågan om vilka kunskaper som behövs för att kunna fungera väl som människa, medborgare och arbetskraft. Flera av de nordiska ländernas rapporter lyfter även fram andra verksamheter som betydelsefulla för att förverkliga EU:s rekommendationer om nyckelkompetenser och betydelsen av samverkan mellan verksamheter. Likaså rapporterar Finland och Norge större projekt. Arbetsmarknadens parter och arbetsgivare får ofta ett stort inflytande. 
Nyckelkompetenser som specifik fråga verkar dock spela en mer undanskymd roll i den nordiska debatten om vuxnas lärande. Svaren från samtliga länder innehåller mer allmänna beskrivningar av utbildningssystem och utbildningssatsningar, vilket kan vara en följd av den begreppsoklarhet som Liedman (2008) lyfter fram avseende EU:s rekommendationer om nyckelkompetenser. Värt att notera är emellertid att flera av länderna i sina rapporter särskilt omnämner vikten av satsningar på mer grundläggande färdigheter som att kunna läsa, skriva och räkna samt kommunikativa färdigheter, kompetenser som också är nära kopplade till möjligheten att få och behålla ett arbete. Det handlar då om vuxna som befinner sig i en utsatt position i arbetsliv och samhälle. Samtidigt lämnar staten över ett stort ansvar till andra aktörer som har sina egna unika institutionella normer, värderingar och intressen.

Mot denna bakgrund rekommenderas att:

- Initiera ett komparativt nordiskt projekt för att undersöka vilken betydelse nämnda samarbetsformer har för formandet av vuxnas utbildningsvägar samt i vilken riktning - och hur - staten styr 


\section{Generelle overvejelser}

Studiet handler om nordisk policy-making i relation til voksen- og efteruddannelse og kompetenceudvikling. Dette emne er relevant for de nordiske lande, fordi de har behov for at kunne sammenligne deres indsats i forhold til nabolandene, men også relevant for lande og grupper af lande uden for Norden. Tænkningen i vidensøkonomi er global.

Når studiet af nordisk policy-making har global relevans, skyldes det, at resultaterne af den nordiske policy-making er enestående. De nordiske lande har evnet at skabe nogle vilkår, der har givet store befolkningsgrupper adgang til formaliseret og ikke-formaliseret kompetenceudvikling, og de nordiske lande havner i toppen af enhver "ranking."

Studiets fire hovedafsnit bidrager på forskellig vis til en samlet fremstilling af „state of the art.“ Teksten er dokumenteret og baseret på omfattende læsning af videnskabelig litteratur, og dette gør det muligt at foretage sammenligninger og diskutere, hvordan og hvorfor de nordiske lande er blevet "frontløbere.“

Sigtet har først og fremmest været at skabe et overblik over de aktuelle kompetencepolitiske initiativer og at anskue disse initiativer i deres nationale kontekst. Landenes vilkår og kulturelle særpræg er forskellige, men studiet demonstrerer, at det nordiske samarbejde er og længe har været et nyttigt redskab for den langsigtede strategiudvikling. Dette samarbejde handlede oprindelig om et mindre politikområde, der kaldtes "folkeoplysning og voksenundervisning" (FOVU), men udviklingen af området kom snart til at give de nordiske lande „kompetencepolitisk“ tyngde i forhandlingerne med EU, fordi det handlede om en konkret eksisterende aktivitet. Det blev på dette område de nordiske lande, der kom til at præge EU. Ikke omvendt. Lissabonstrategien, men også senere EU-initiativer er påvirket af de nordiske landes evne til at skabe resultater.

Undersøgelsen dokumenterer de nordiske landes indsats i forhold til en kompetencepolitisk dagsorden, der er under stadig forandring. Det er nærliggende at se tilbage på situationen forud for Lissabonstrategiens vedtagelse, og det er muligt at vise, hvordan de nordiske lande også dengang var de fremmeste. Et komparativt studie, som Nordisk Ministerråd 
publicerede under titlen „Nordisk løft for voksnes læring“ (2000), giver et øjebliksbillede af datidens nationale strategier. De etablerede strategier, der havde været effektive i 1980erne og 1990erne, var på retur. Det var f.eks. statslig detailstyring, offentligt monopol og fokus på udbudsstyring. Nye strategier var dengang: Lokal og regional styring, institutionel autonomi, fokus på efterspørgselsstyring og orientering mod arbejdslivet.

Dette nye studie kortlægger tendenser i nordisk policy-making, og det sætter fokus på tre udvalgte temaer. Undersøgelsen viser, at de nordiske lande er i færd med at justere deres kompetencepolitiske kurs. Dette skyldes dels, at borgernes, samfundets og arbejdslivets behov er blevet anderledes og dels, at der er skabt ny viden og indvundet erfaringer om, hvad der virker.

\subsection{Hovedkonklusion}

I de nordiske lande gør arbejdsmarkedets parter og myndighederne en langsigtet indsats for at opbygge og fastholde et tillidsfuldt samarbejde. Studiet viser, hvordan dette samarbejde er blevet intensiveret i bredden og i dybden. Det omfatter det nationale niveau - hvor flere lande har oprettet nationale råd, hvor arbejdsmarkedets parter har en markant repræsentation - og ofte et regionalt, et lokalt og et institutionelt niveau. Myndighederne er blevet mindre synlige og tilsyneladende ikke mindre effektive, og arbejdsmarkedet parter er gået ind i et "forpligtende partnerskab." Et nyt træk er, at voksne brugere og uddannelsesinstitutioner visse steder har opnået repræsentation i områdets mange organer. Arbejdsmarkedets parter tager i stigende omfang ansvar for initiativers implementering, hvilket bidrager til at styrke effektiviteten af de nationale systemer for kompetenceudvikling. Det er imidlertid slående, at evaluering mhp at kunne måle initiativernes effekt synes at spille en begrænset rolle i drøftelserne mellem arbejdsmarkedets parter og myndighederne.

Studiets dataindsamling og arbejdet med videnskabelig litteratur har i sagens natur drejet sig om policy-making på det nationale niveau. Det indebærer, at vor viden om, hvad der reelt foregår i det lokale samspil mellem uddannelsesinstitutioner og virksomheder, er begrænset. Det er kun muligt at udtale sig om de intentioner for samspillet, der er formuleret på nationalt niveau. Den konkrete aktivitet inden for temaet er derfor underbelyst. Det antages imidlertid, at en effektiv strategi for udvikling af samspillet mellem disse to former for organisation - der er forskellige 
m.h.t. kultur, struktur og vilkår - kan fremmes, hvis myndighederne og arbejdsmarkedets parter udvikler forslag til nationale strategier for en uafhængig, professionel virksomhedsrådgivning.

Studiet af de nordiske landes indsatser for at styrke voksnes nøglekompetencer har vist, at landene på dette område følger en selvstændig kurs i forhold til de retningslinjer, der anbefales af EU. Baggrunden for dette synes at være, at de nordiske lande fastholder de initiativer, der understøtter kortuddannedes muligheder for kompetenceudvikling. Det har medført, at landene „overopfylder" i forhold til EUs anbefalinger. Det vurderes, at indsatsen på dette område aktuelt er så effektiv, at de nordiske lande næppe ville vinde noget ved at ændre deres faste kurs. Der er snarere anledning til at overveje at gennemføre en sammenlignende analyse af indsatsen for kortuddannede, der vil kunne give andre lande kendskab til de nordiske modeller. Begrebet „nøglekompetence“ forstås i denne sammenhæng som en politisk (dvs. en uvidenskabelig) „facitliste“ for EUs medlemslande. De nordiske lande har mange eksempler på god praksis inden for dette område.

\subsection{Hovedanbefalinger}

For 10 år siden fandt forskerne bag „Nyfikna sinnen..." (Nordisk Ministerråd 2001a) mange ligheder, men også væsentlige forskelle mellem de nordiske landes initiativer i forhold til voksnes læring. Det vurderes, at disse forskelle i dag er blevet mindre, hvilket indebærer, at mulighederne for at opnå relevante resultater gennem komparative studier er blevet større. Relevante resultater forstås i denne sammenhæng som identifikation af de strategier, der vil kunne have positiv effekt $\mathrm{i}$ andre lande.

Ved formuleringen af det udbud, der førte til gennemførelsen af dette studie, satte Nordisk Ministerråd fokus på strategier vedrørende livslang læring, ikke voksnes læring. Det anbefales, at denne tilgang fastholdes. Hovedargumentet er, at de nordiske lande er i besiddelse af konkrete erfaringer med udviklingen af et „lærende samfund“, hvor man søger at inddrage hele befolkningen, der er enestående på verdensplan.

De enkelte lande i Norden gennemfører deres egne erfaringsopsamlinger, der fungerer som pejlemærker ved formuleringen af nationale strategier. Ved at kortlægge, analysere og sammenligne de nationale erfaringer vil disse kunne nyttiggøres til gavn for livslang læring i ikke-nordiske lande, i nordiske lande og i det nordiske land, der oprindelig formulerede strategien. 
Vilkårene for komparative studier af livslang læring er siden 2001 blevet væsentligt bedre, idet landene kontinuerligt forsker i livslang læring, EU understøtter en sådan forskning og der er siden publiceringen af „Nyfikna sinnen..." etableret gode muligheder for at gennemføre omfattende statistiske undersøgelser.

Den aktuelle implementering af nationale kvalifikationsrammer (NQFs) vurderes at forøge Nordens muligheder for at opnå relevante resultater gennem komparative studier. Dette skyldes at:

- alle nordiske lande implementerer NQFs på samme tid

- retningslinierne for udvikling af $\mathrm{NQFs}$ er de samme

Nationale strategier for livslang læring og NQFs indgik i EUs arbejdsprogram „Education and Training 2010.“

Når alle fem lande implementerer NQFs, der bygger på et fælles grundlag, forbedrer det vilkårene for komparative studier af de nordiske befolkningers tilegnelse af viden, færdigheder og kompetencer. Da EU i arbejdsprogrammet „Education and Training 2020“ tænker livslang læring sammen med „mobilitet“, gør dette målinger af de nordiske befolkningers mobilitet i forhold til de otte kvalifikationsniveauer relevante.

Denne undersøgelse har dokumenteret en tendens til at styrke den regionale koordinering af samspillet mellem udbydere, virksomheder og arbejdsmarkedet parter. Derfor anbefales komparative studier af formuleringen samt effekten af regionale strategier for livslang læring.

Konkret anbefales komparative studier af:

- Nationale og regionale strategier, der modvirker marginalisering og understøtter kortuddannede i forhold til arbejdsliv og samfundsliv

- Formuleringen samt effekten af regionale strategier for livslang læring og mobilitet

- Samspillet mellem nationale, regionale og lokale myndigheder i det konkrete samarbejde med udbydere, virksomheder og arbejdsmarkedets parter

- Udbydernes, virksomhedernes og arbejdsmarkedets parters erfaringer med den konkrete anvendelse af NQFs

- De nordiske landes indsats for kortuddannede, der vil kunne give andre lande kendskab til de nordiske modeller 



\section{Referencer}

Althingi (2010). Lög um framhaldsfræðslu. nr. 27 af 31. mars 2010.

Antikainen, A. (2006). „In Search of a Nordic Model in Education.“ In: Scandinavian Journal of Educational Research, Vol. 50, No. 3.

Antikainen, A. \& Kauppila, J. (2002). „Educational generations and the futures of adult education: a Nordic experience. "In: International Journal of Lifelong Education, Vol. 21, No. 3.

Baldersheim, H. \& Ståhlberg, K. (2002). From guided democracy to multi-level. Trends in Central-Local Relations. In: Local Government Studies, Vol. 28, No. 3.

Balzer, C. \& Rusconi, A. (2007). „From the European Commission to the Member States and Back - A Comparison of the Bologna and the Copenhagen Process." In: New Areas of Education Governance. The Impact of International Organizations and Markets on Educational Policy Making. London: Palgrave Macmillan.

Bengtsson, J. (2008). National Strategies for Implementing Lifelong Learning (LLL): an International Perspective. http://www.pascalobservatory.org

Bomberg, E. (2007). „Policy learning in an enlarged European Union: environmental NGOs and new policy instruments." In: Journal of European Public Policy, Vol. 14, No. 2.

Burke, J. W. (1989). (Ed.), Competency Education and Training. The Falmer Press.

Byholt, V. (2009). Nye muligheter - et samarbeidsprosjekt for å få unge voksne med manglende grunnleggende ferdigheter i arbeid. Vox. Projektrapport.

Carlgren, I., Forsberg, E. \& Lindberg, V. (2009). Perspektiv på den svenska skolans kunskapsdiskussion. Stockholm: Stockholms universitetsförlag.

Carlson, M. (2004). „Restructuring of Swedish Adult Education: the involvement of economists and politicians in education policy." In: Troman, G., Jeffrey, G. \& Walford, G. (eds). Identity, Agency and Social Institutions. Studies in Educational Ethnography, vol. 10. . Amsterdam: Elsevier.

Commission of the European Communities (2003). Commission staff working document. Implementation of the „Education and Training 2010“ programme. Brussels: Commission of the European Communities.

Dahl, B. (2003a). „Tensions between the European and the Nordic dimension in education, with particular reference to Sweden." In: Implementing European Union Education and Training Policy. A Comparative Study of Issues in Four Member States. Dordrecht: Kluwer Academic Publishers.

Dahl, B. (2003b). „The Impact of EU education and training policies in Sweden.“ In: Implementing European Union Education and Training Policy. A Comparative Study of Issues in Four Member States. Dordrecht: Kluwer Academic Publishers.

Danmarks evalueringsinstitut (EVA) (2010). Anerkendelse af realkompetencer $i$ nordisk perspektiv. Rapport. København: EVA. 
Dølvik, J. E. (2007). The Nordic regimes of labour market governance: From crisis to success-story? Oslo: Fafo.

Døving, E. \& Skule, S. (2002). Evaluering av Kompetanseutviklingsprogrammet. Undervejsrapport 2002. Bergen: Samfunns- og næringslivsforskning.

ECON (2007). Evaluering av Program for basiskompetanse i arbeidslivet (BKA) Utarbeidet for Kunnskapsdepartementet. Rapport 2007:077.

Ehlers, S. (2006). „The decline and fall of „folkeoplysning“ and adult education: Nordic policy making during the transition from adult education to adult learning." In: Identity, education and citizenship - multiple interrelations. Frankfurt am Main: Peter Lang.

Ehlers, S. (2009). „Livslang læring som politisk strategi i 1900-tallets Danmark. Samspillet mellem civilsamfund, stat og marked.“ In: Ehlers, S. Uddannelseshistorie 2009.

Elvander, N. (2002). „The Labour Market Regimes in the Nordic Countries: A Comparative Analysis." In: Scandinavian Political Studies, Vol. 25, No. 2.

Eide, K. (1999). „Samfunnsendring og livslang læring.“ In: Hvor kommer utdanningspolitikken fra? Oslo: Norsk Institutt for studier av forskning og utdanning.

Engesbak, H. \& Stubbe, T. A. (2008). „Bureaucratic responses to policy change: implementation of adult education policy in Norway." In: International Journal of Lifelong Education, Vol. 27, No. 1.

Ertl, H. (2006). „European Union policies in education and training: the Lisbon agenda as a turning point." In: Comparative Education, Vol. 42, No. 1.

EU (1995). Teaching and Learning - Towards the Learning Society. White Paper on Education and Training. Lanham: Bernan Associates.

EU (2006). Europaparlamentets och rådets rekommendation av den 18 december 2006 om nyckelkompetenser för livslångt lärande (2006/962/EG). http://eurlex.europa.eu/LexUriServ/LexUriServ.do?uri=0J:L:2006:394:0010:0018:sv:PDF Hämtat maj 2010.

EU (2010). Europe 2020. Integrated Guidelines for the Economic and Employment Policies of the Member States. Broschyr. Europa-kommissionen. http://ec.europa.eu/eu2020/pdf/Brochure\%20Integrated\%20Guidelines.pdf Hämtad september 2010.

EU-tidende (2006). „Europa-Parlamentets og Rådets afgørelse nr. 1720/2006/EF af 15. november 2006 om et handlingsprogram for livslang læring" i: EU-Tidende nr. L 327 af 24/11/2006.

European Commission (2001). Making a European Area of Lifelong Learning a Reality. Communication from the Commission.

European Commission. (2004). Implementation of „Education and Training Work programme. “Working Group B „Key Competencies.“ Education. Lifelong Learning Policy Document.

European Commission (2007). 2007 National Report on the Implementation of the Education and Training 2010 Work Programme. Norway. Udskrevet 18. oktober 2010 fra http://ec.europa.eu/education/lifelong-learning-policy/doc/ nationalreport08/no07_en.pdf

European Communities (2008).The European Qualifications Framework for Lifelong Learning (EQF). http://ec.europa.eu/education/policies/educ/eqf/eqf08_en.pdf 
Europeiska kommissionen (2009). Den europeiska referensramen för kvalifikationer för ett livslångt lärande. Luxemburg: Byrån för Europeiska gemenskapernas officiella publikationer.

Europeiska rådet (2010). Europeiska rådet 25-26 mars 2010-Slutsatser-EUCO 7/10 CO EUR 4 CONCL 1.

EUT C142/2002. „Detaljerat arbetsprogram för uppföljningen av målen för utbildningssystemen i Europa." In: Europeiska gemenskapernas officiella tidning. 14/6 2002.

Faure, Edgar, et. al. (1972). Learning to be. The world of education today and tomorrow. Paris: UNESCO.

Fejes, A. (2006). Constructing the Adult Learner: A Governmentality Analysis. Linköping: Linköping University. Linköping Studies in Education and Psychology.

Fejes, A. (2010). Discourses of employability: Constitutiong the responsible citizen. Studies in Continuing Education.32 (2). pp. 89-102.

Finansdepartementet (2009). Budgetpropositionen för år 2010, utg.omr. 16. Prop. 2009/10:1. Stockholm: Finansdepartementet.

Finansministeriet (2006). Livslang opkvalificering og uddannelse for alle på arbejdsmarkedet. København: Finansministeriet.

Friberg, N. \& Modig, A (2010). Yrkesutbildning för vuxna i de nordiska länderna, NVL.

Globaliseringsrådet (2009). Bortom krisen. Om et framgångsrikt Sverige i den nya globala economin. Globaliseringsrådets slutrapport. Stockholm: Globaliseringsrådet.

Grek, S. (2009). „Governing by Numbers: the PISA „effect“ in Europe.“ In: Journal of Education Policy, Vol. 24, No. 1.

Grue-Sørensen, K. (1974). Almen pædagogik. En håndbog i de pædagogiske grundbegreber, København: Gjellerup.

Hartvig Pedersen, J. \& Holmquist-Larsen, N. (1994). Arbejdsministeriet. Et rids af fortid, opgaver og organization. København: Arbejdsministeriet.

Heikkinen, A. (2007). „Fragmentation of Adult Education Research.“ In: Adult Education - Liberty, Fraternity, Equality? Nordic Views on lifelong learning. Turku: Finnish Educational Research Association.

Hulkari, Kirsti \& Paloniemi, Susanna. (2008). „The NOSTE programme promoting lifelong learning for low-educated older workers in Finland." In: Innovative learning measures for older workers. Cedefop Panorama Series, 159. Luxembourg, Office for official publications of the European Communities.

Husén, T. (1974) The Learning Society, London: Methuen.

Husén, T. \& Härnqvist, K. (2000). Begåvningsreserven. En återblick på ett halvsekels forskning och debatt. Årsböcker i svensk undervisningshistoria.

Jacobsson, K. \& Noaksson, N. (2006). Kampen om kunskapen: OECD och EU om arbetsmarknaden. I K. Fernler \& C-F Helgesson (red). Kloka regler. Lund: Studentlitteratur.

Jakobsson, E. (2007). Mot en ny vuxenutbildningspolitik?: regional utveckling som policy och praktik. Linköping: Linköpings Universitet.

Jessup, G. (1991). Outcomes: NVQs and the emerging model of Education and Training. The Falmer Press. 
Jørgensen, J. R. (2010). Answers to Nordic B Denmark. Questionnaire on implementation and evaluation of general strategies for adult learning. Danish School of Education, Aarhus University.

Kommissionen for de europæiske fællesskaber (2006). Meddelelse fra kommissionen. Voksenuddannelse: Det er aldrig for sent at lære, KOM(2006) 614 endelig. Bruxelles: Kommissionen for de europæiske fællesskaber.

Kommissionen for de europæiske fællesskaber (2007). Meddelelse fra kommissionen til Rådet, Europa-parlamentet, Det Europæiske Økonomiske og Sociale Udvalg og Regionsudvalget. Handlingsplan for voksenuddannelsen: Det er altid et godt tidspunkt at lære KOM(2007) 558 endelig. Bruxelles: Kommissionen for de europæiske fællesskaber.

Kunnskapsdepartementet (2007a). Stortingsmelding $n r .16 . .$. og ingen sto igjen. Tidlig innsats for livslang læring. Oslo: Kunnskapsdepartementet.

Kunnskapsdepartementet (2007b). Tilstandsrapport om livslang læring i Norge. Status, utfordringer og innsatsområder. Oslo: Kunnskapsdepartementet

Kunnskapsdepartementet (2009a). Stortingsmelding nr. 44.Utdanningslinja. Oslo: Kunnskapsdepartementet.

Kunnskapsdepartementet (2009b). Lov om voksenopplæring (voksenopplæringsloven), LOV-2009-06-19-95. Oslo: Kunnskapsdepartementet.

Liedman, S-E. (2008). Nycklar till ett framgångsrikt liv? Om EU:s nyckelkompetenser. Skolverket. Intern rapport.

Lumsden Wass, K. (2004). Vuxenutbildning i omvandling. Kunskapslyftet som ett sätt att organisera förnyelse. Göteborg: Acta Universitatis Gothoburgensis. Gothenburg Studies in Educational Sciences.

Mailand, M. (2008). Corporatism in Denmark and Norway - yet another century of Scandinavian corporatism? Not published. Copenhagen: Department of Sociology, University of Copenhagen.

Mailand, M. (2009). „Perspektiven des skandinavischen korporatismus Dänemark und Norwegen im Vergleich." In: WSI-Mitteilungen, 2009(1).

Mark, E. (2009). Livslångt lärande ur bildningsperspektiv som strategi för högskolan. Grundtviginstitutetvid Göteborgs universitet, rapport nr 7. Göteborg: Göteborgs universitet.

Milana, M., \& Larson, A. (2010). BAEA - Becoming Adult Educators in the European Area. National Report: Denmark. Copenhagen: Danish School of Education, Aarhus University.

Ministeriet for Videnskab, Teknologi og Udvikling (2003). Viden i vækst - regeringens vidensstrategi. Baggrundsrapport. København: Ministeriet for Videnskab, Teknologi og Udvikling.

Ministry of Education (2007). Development of lifelong learning in Finland and the Education and Training 2010 work programme of the European Union. Education and Training 2010 - Finland's interim report for 2005-2007. Helsinki: Ministry of Education.

Ministry of Education (2008). UNESCO - National Report of Finland (2008). Helsinki: Ministry of Education.

Mortensen, L. (2001). „Videreuddannelsessystemet for voksne - en ramme for livslang læring." I: Uddannelse, Årgang 34 nr. 9 (2001). 
Myndigheten för yrkeshögskolan (2010). Förslag till ett svenskt kvalifikationsramverk. Myndigheten för yrkeshögskolans återrapportering 2010. Diarienr: YH 2010/YH2042. http://www.eqfinfo.se/aktuellt/ Hämtad 15 oktober 2010.

Mäenpää, H (2007). Utbildning och forskning 2007-2012. Preliminär kalkyl över målen för utbildningsutbudet 2012. Undervisningsministeriets arbetsgruppspromemorior och utredningar 2007:26.

Mørch Jacobsen, K. (1982). Voksenundervisning - for hvem til hvad? København: Nordisk Ministerråd.

Nordby, T. (1999). Samvirket mellom organisasjoner og stat: Norge. Makt- og demokratiutredningens rapportserie, Rapport 4. Oslo: Unipub.

Nordic Council of Ministers (1996). Golden Riches in the Grass. Lifelong learning for all. Copenhagen: Nordic Council of Ministers.

Nordic Council of ministers (1997). Lifelong Learning: From Idea to Reality. Report from the Nordic-European Conference at Eigtveds Pakhus. Copenhagen: Nordic Council of Ministers.

Nordisk Ministerråd (1978). Nye veier i voksenopplæring - en kartlegging av forsknings- og utviklingsarbeid i Norden. Stockholm: Nordisk Utredningsserie no. 41.

Nordisk Ministerråd (1983). Nye veje i voksenundervisning og folkeoplysning. En kortlægning af forskning, forsøgs- og udviklingsarbejde i Norden 1978-1983. Кøbenhavn: Nordisk Ministerråd.

Nordisk Ministerråd (1988). Handlingsplan for nordisk kulturelt samarbejde. København: Nordisk Ministerråd.

Nordisk Ministerråd (1995). Guldtavlerne i græsset - livslanglæring for alle, $\mathrm{nr}$. 1995:002. København: Nordisk Ministerråd.

Nordisk Ministerråd (2000). Nordisk løft for voksnes læring. København: Nordisk Ministerråd.

Nordisk Ministerråd (2001a). Nyfikna sinnen - Nordisk vuxenutbildning i jämförelse, nr. 2001:20. København: Nordisk Ministerråd.

Nordisk Ministerråd (2001b). Nordisk kartlegging om landenes parallelle initiativer knyttet til realkompetanse, nr. 2001:530. København: Nordisk Ministerråd.

Nordisk Ministerråd (2009). Komparativt studie af de nordiske læreruddannelser. TemaNord 2009:505. København: Nordisk Ministerråd.

Nordisk Råd (1974). Voksenopplæring i de nordiske lande - en kartlegging. Nordisk samarbeid på undervisningsområdet. København: Sekretariatet for nordisk kulturelt samarbejde i samarbejde med Nordisk Råd.

Norges offentlige utredninger (1986). Livslang læring. NOU 1986:23. Oslo: Norges offentlige utredninger

Norges offentlige utredninger (2001). Støtte til livsopphold ved utdanningspermisjon. NOU 2001:25. Oslo: Statens forvaltningstjeneste, Informasjonsforvaltning.

OECD (1989). Education and the economy in a changing society. Paris: OECD

OECD (1996). Lifelong learning for all. Paris: OECD.

OECD (2001b). Thematic Review on Adult Learning: Finland. Country Note. www.oecd.org

OECD (2002). Lifelong Learning in Norway. Reviews of national policies of education. Paris: OECD. 
OECD (2005). Definition and Selection of Key Competencies: Executive Summary. http://www.oecd.org/dataoecd/47/61/35070367.pdf

Pedersen, 0. K. (2007). Konkurrencestaten - den endeløse reform. http://www.cbs.dk/Forskning/Institutter-centre/Institutter/DBP/ Hoejreboks/Nyheder/7-artikler-i-Politiken/(language)/dan-DK.

Pekkarinen, J. (1992). „Corporatism and Economic Performance in Sweden, Norway and Finland." In: J. Pekkarinen, M. Pohjola \& B. Rowthorn, Social Corporatism: A Superior Economic System? Oxford: Oxford University Press.

Pepin, L. (2007). „The History of EU Cooperation in the Field of Education and Training: how lifelong learning became a strategic objective." In: European Journal of Education. Volume 42, Issue 1.

Regeringen (2006). Fremgang, fornyelse og tryghed. Strategi for Danmark i den globale økonomi. København: Regeringen.

Regeringen (2008). Yrkeshögskolan. Regeringens proposition 2008/09:68. Stockholm: Regeringen.

Rinne, R. \& Vanttaja, M. (2000). „New directions of adult education policy in Finland." In: Reform and Policy. Adult education research in Nordic countries. Trondheim: Tapir Academic Press.

Rinne, R. et al. (eds.) (2007). Adult Education - Liberty, Fraternity, Equality? Nordic Views on lifelong learning. Turku: Finnish Educational Research Association.

Riksrevisjonen (2008). Riksrevisjonens undersøkelse av tilbudet til voksne om grunnskoleopplæring og opplæring på videregående skolenivå. Dokument nr. 3:14 (2007-2008).

Rubenson, K. (1994) „Adult Education Policy in Sweden 1967-1991.“ In: Review of Policy Research. Vol. 13, No. 3-4.

Rubenson, K. Tuijnman, A. \& Wahlgren, B. (1999). Från kunskapslyft till en strategi för livslångt lärande: ett perspektiv på svens vuxenutbildningspolitik. I: SOU 1999:141. Från Kunskapslyftet till en strategi för livslångt lärande - Ett perspektiv på svensk vuxenutbildningspolitik. Kommittén om ett nationellt Kunskapslyft för vuxna. Stockholm.

Rubenson, K. (2006). „Constructing the lifelong learning paradigm: Competing visions from the OECD and UNESCO." In: S. Ehlers (Ed.), Milestones towards lifelong learning systems (pp. 151-170). Copenhagen: Danish University of Education Press.

Rychen, D.S. (2004). „Key Competencies for All: an Overarching Conceptual Frame of Reference." In: D.S. Rychen. \& A. Tiana, A. Developing Key Competencies in Education: Some Lessons from International and national Experience. UNESCO: International Bureau of Education.

Rychen, D.S. \& Salganik, L.H. (Eds) (2003). Key competencies for a successful life and a well functioning society. Gottingen: Hogrefe \& Huber.

Rychen, D.S. \& Tiana, A. (2004). Developing Key Competencies in Education: Some Lessons from International and national Experience. UNESCO: International Bureau of Education.

Rådet for den europæiske union (2004). Uddannelse og erhvervsuddannelse 2010. Lissabon-strategiens succes afhænger af gennemførelsen af hastende reformer. Fælles midtvejsrapport fra Rådet og Kommissionen om gennemførelsen af det de- 
taljerede arbejdsprogram for opfølgning af uddannelsessystemernes mål i Europa. Bruxelles: Rådet for den europæiske union.

Rådet for den europæiske union (2008). Rådets konklusioner af 22. maj om voksenuddannelse. Brussel: Rådet for den europæiske union.

SCB (2007). Förvärvsinkomster och bidrag i de nordiska länderna under 1990-talet. Örebro. Statistics Sweden. http://www.paula-liukkonen.se/pdf/V\%E4lf\% E4rdsrapporten\%20slutversionen\%20fr\%E5n\%20SCB.pdf Hämtad oktober 2010.

Schuetze, H. G. (2006). „International concepts and agendas of lifelong learning.“ In: Compare, Vol. 36, No. 3.

SFS 2010:2016. Förordning om statsbidrag för lärlingsutbildning för vuxna

Skolverket (2010). Kartläggning av kvalifikationsbeskrivningar för EQF. PM. Dnr 69-2010:163.

Sonne, L. (2007). NORDEK. A Plan for Increased Nordic Economic Cooperation and Integration. 1968-1970. Helsinki: Finnish Society of Sciences and Letters.

Statsrådet (2009). Statsrådets förordning om rådet för livslångt lärande. Helsingfors: Statsrådet

Stefánsdottir, D. (2001). Vocational education and training in Iceland. Short description. Thessaloniki: CEDEFOP.

Ståhlberg, K. og Klausen, K. K. (1998). New Public Management i Norden: nye organisations- og ledelsesformer i den decentrale velfærdsstat. Odense: Odense Universitetsforlag.

Telhaug, A. O. et al. (2004). „From Collectivism to Individualism. Education as Nation Building in a Scandinavian Perspective." In: Scandinavian Journal of Educational Research, Vol. 48, No. 2.

Tiana, A. (2004). „Developing Key Competencies in Education Systems: Some Lessons from International Studies and National Experiences." In: D.S. Rychen. \& A. Tiana, A. Developing Key Competencies in Education: Some Lessons from International and national Experience. UNESCO: International Bureau of Education.

Tuijnman, A. (1992). „Paradigm Shifts in Adult Education.“ In: Tuijnman, A. Learning Across the Lifespan: Theories, Research, Policies. Pergamon Press.

Tuijnman, A. (1997). „Nödvändiga basfärdigheter för vuxna i kunskapssamhället.“ In: Mäkitalo, Å. \& Olsson, L-E. Vuxenpedagogik i teori och praktik. Kunskapslyftet $i$ fokus. En antologi från Kommittén om ett nationellt kunskapslyft för vuxna. SOU 1997:158. Stockholm: Utbildningsdepartementet.

Tuijnman, A. (2003). „A Nordic model“ of adult education: What might be its defining parameters?.“ In: International Journal of Educational Research, Vol. 39.

Tuijnman, A. \& Bostrøm, A-K. (2002). „Changing notions of lifelong education and lifelong learning." In: International Review of Education, Vol. 48, No. 1/2.

Tuomisto, J. (1998). „Market-Oriented Adult Education Policy - a Finnish Perspective." In Alheit, P. \& Kammler, E. (eds.), Lifelong Learning and its Impact on Social and Regional Development. Bremen: Donat Verlag.

Tønder Jessing, C. et al. (2010). Bedre vejledning og rådgivning til beskæftigede og virksomheder. Afsluttende evaluering af 22 voksenvejledningsnetværk. København: Nationalt Center for Kompetenceudvikling. 
Tøsse, S. (2004). „Målsettning, rolle og funsjon i vaksenopplæringa 1945-2004.“ In: Utfordringar for voksnes læring. Et nordisk perspektiv. Festskrift til Lars Arvidson. Trondheim: Vox/Mimer.

Tøsse, S. (2005). Folkeopplysning og vaksenopplæring. Idear og framvekst gjennom 200 år. Oslo: Didakta Norsk Forlag.

Tøsse, S. (2006). „Lifelong learning and new competence. The reasoning behind the Norwegian Adult Education Reform Policy in the 1980's and 1990's." In: Milestones towards lifelong learning systems. Copenhagen: Danish Education University Press.

Undervisningsministeriet (2002). Bedre uddannelser. Handlingsplan. København: Undervisningsministeriet.

Undervisningsministeriet (2004). Utbildning och forskning 2003-2008. Helsingfors: Undervisningsministeriet.

Undervisningsministeriet (2007). Danmarks strategi for livslang læring - Uddannelse og opkvalificering for alle. København: Undervisningsministeriet.

Undervisningsministeriet (2009a). Den danske kvalifikationsramme for livslang læring. Et redskab til at få overblik over uddannelser i Danmark. Broschyr.

Undervisningsministeriet (2009b). Nationell referensram för examensbaserat och övrigt kunnande. Undervisningsministeriets arbetsgruppspromemoror och utredningar 2009: 24. D nr 40/040/2008.

http://www.oph.fi/instancedata/prime_product_julkaisu/oph/embeds/120545_ nqf-muistio09_SV_lopullinen.pdf Hämtad oktober 2010.

Undervisningsministeriet (2009c). Statsrådets förordning om rådet for livslångt lärande af 20. maj 2009.

Undervisningsministeriet (2010). Vejledning for opsøgende vejledning og rådgivning.

Undervisnings- och kulturministeriet (u.å.). Arbetskraftpolitisk utbildning. Hentet fra Internettet 26. oktober, 2010, fra adressen

http://www.minedu.fi/OPM/Koulutus/aikuiskoulutus_ja_vapaa_sivistystyoe/aik uiskoulutusjaerjestelmae/tyoevoimapoliittinen_koulutus/?lang=sv.

Undervisnings- och kulturministeriet (2007). Pressmeddelande - Ledningsgrupp skall förbereda en totalreform av den yrkesinriktade vuxenutbildningen $(2007,17$ 08-2007). Helsingfors: Undervisnings- och kulturministeriet. Hentet fra Internettet 26. oktober, 2010, fra adressen: http://www.minedu.fi/OPM/Tiedotteet/2007/08/Johtoryhma_ammatillisesti_s uuntautuneen_aikuiskoulutuksen_kokonaisuudistus.html?lang=sv

Undervisnings- och kulturministeriet (2008). Utbildning och forskning 2007-2012. Utvecklingsplan. Undervisningsministeriets publikationer 2008:10. Helsingfors: Undervisnings- och kulturministeriet.

Undervisnings- och kulturministeriet (2009). Utvecklingsprogram för fritt bildningsarbete 2009-2012. Helsingfors: Undervisnings- och kulturministeriet.

Ure, O.B. (2007). Lifelong Learning in Norway. A Deflating Policy Balloon or an Act of Piecemeal Implementation?. Oslo: FAFO.

Utbildningsdepartementet (2001a). Vuxnas Lärande och utvecklingen av vuxenutbildningen. Prop. 2000/01:72. Stockholm: Utbildningsdepartementet

Utbildningsdepartementet (2001b). Den öppna högskolan. Prop. 2001/02:15. Stockholm: UtbildningsdepartementetUtbildningsdepartementet (2007). Kun- 
skapsdriven tillväkst - En första rapport från Globaliseringsrådet. Stockholm: Utbildningsdepartementet.

Waldow, F. (2009). „Undeclared imports: Silent borrowing in educational policymaking and research in Sweden." In: Comparative Education, Vol. 45, No. 4.

Wendt, F. (1979). Nordisk Råd 1952-1978, Struktur-arbejde-resultater. Stockholm: Nordiska Rådet.

Weymann, A. et al. (2007). „International Organizations, Markets and the National State in Education Governance." In: New Arenas of Education Governance. The Impact of International Organizations and Markets on Educational Policy Making. London: Palgrave Macmillan.

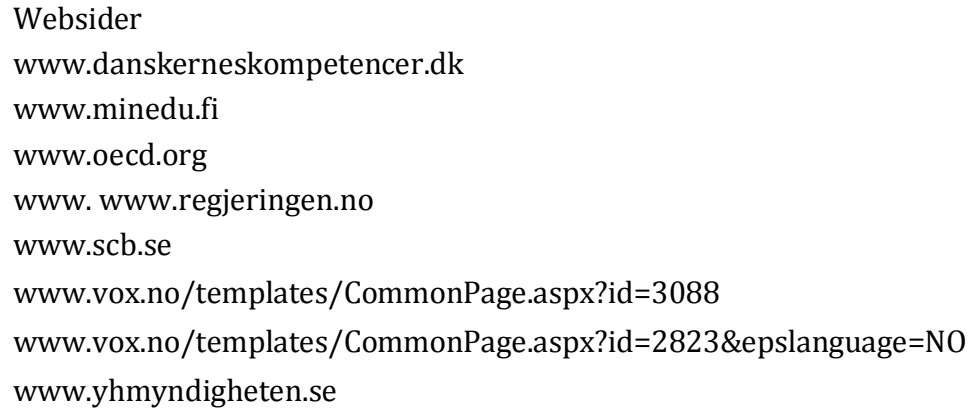

Nationale rapporter, EUs Education and Training 2010 Work Programme

Denmark: National Report on the Implementation of the Education and Training 2010 Work Programme (2009)

Finland: National Report on the Implementation of the Education and Training 2010 Work Programme (2009)

Iceland: National Report on the Implementation of the Education and Training 2010 Work Programme (2009)

Norway: National Report on the Implementation of the Education and Training 2010 Work Programme (2009)

Sweden: National Report on the Implementation of the Education and Training 2010 Work Programme (2009)

Notat fra fire ministerier (2007) 



\section{Bilag}

\subsection{Oversigt over det ordinære uddannelsessystem i Danmark}

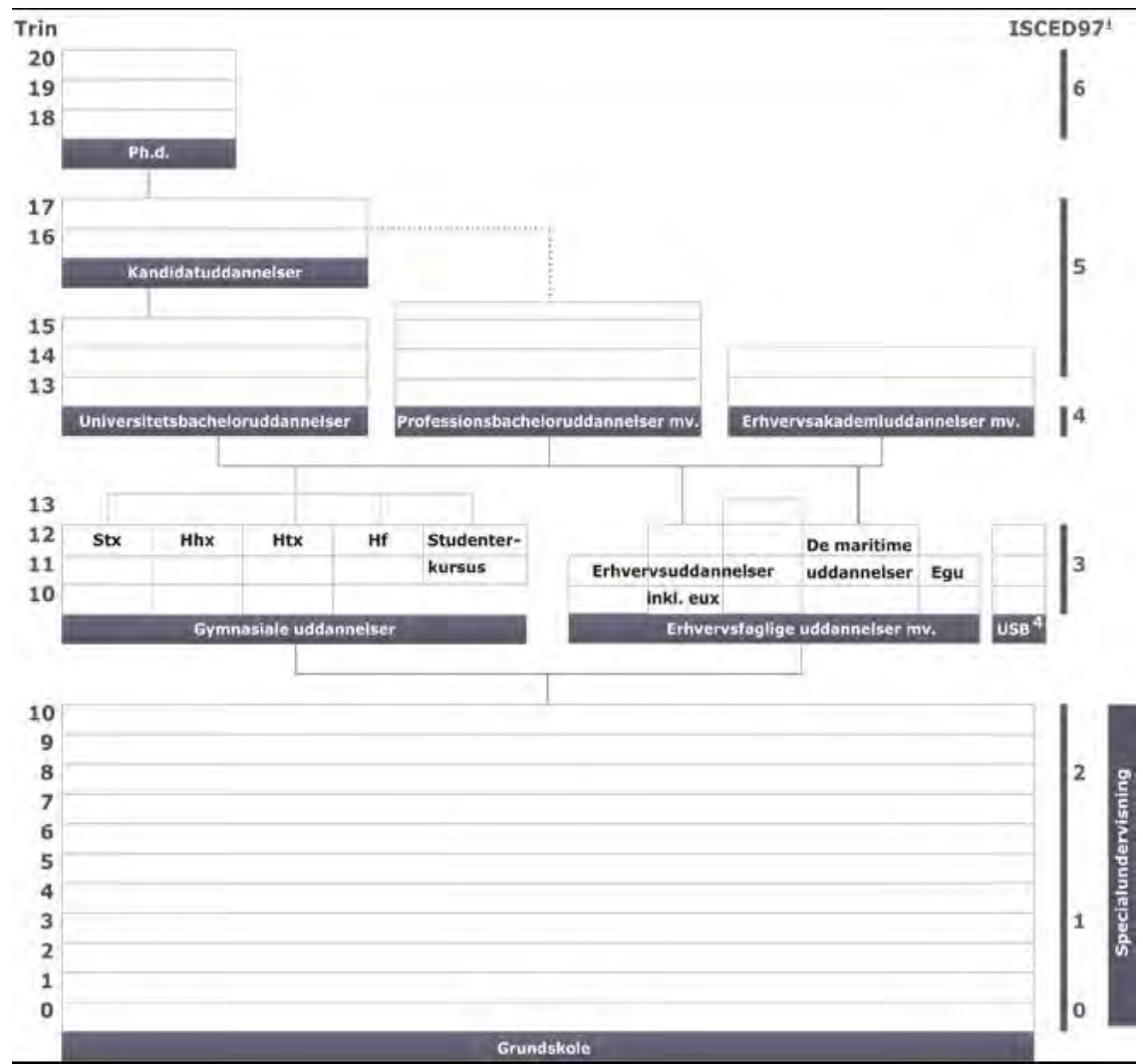

Kilde: www.uvm.dk 


\subsection{Oversigt over voksen- og efteruddannelsessystemet i Danmark}

Det ordinære uddannelsessystem Voksen- og efteruddannelsessystemet

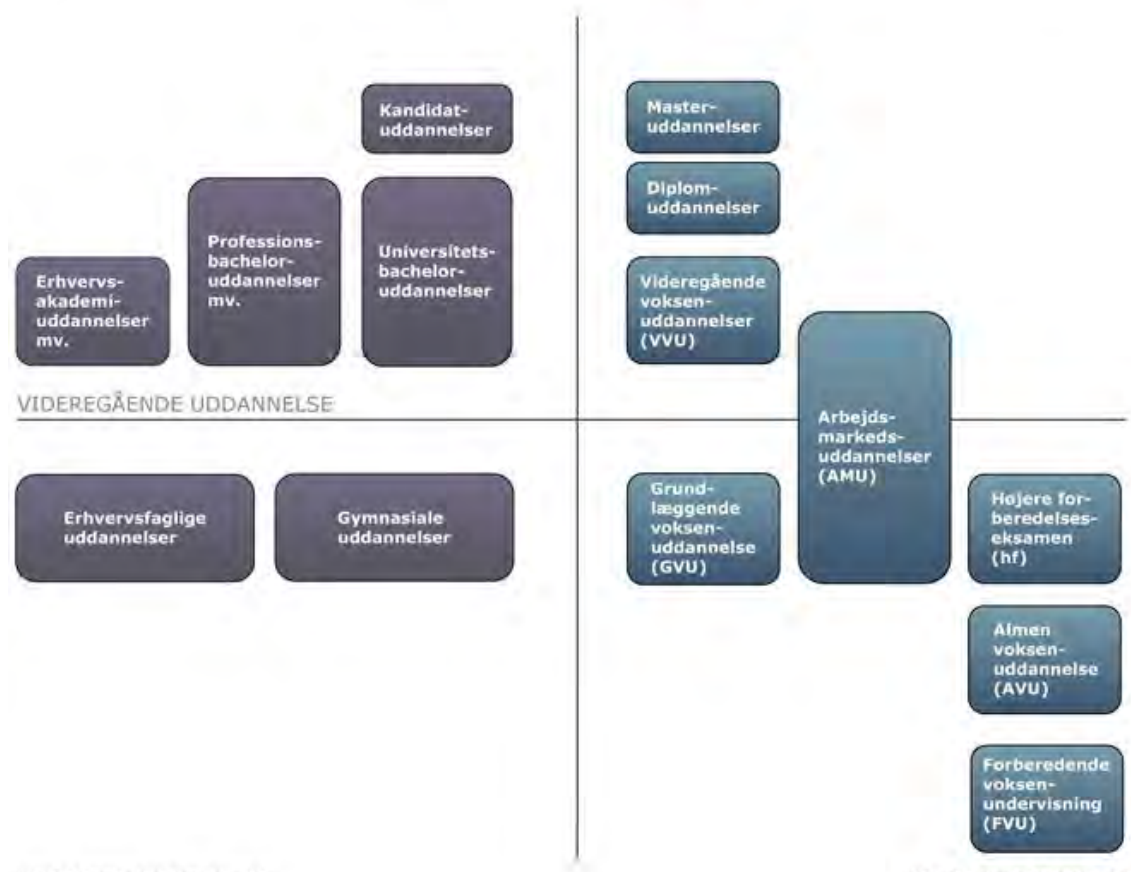

Kilde: http://www.uvm.dk 


\subsection{Oversigt over uddannelsessystemet i Finland}

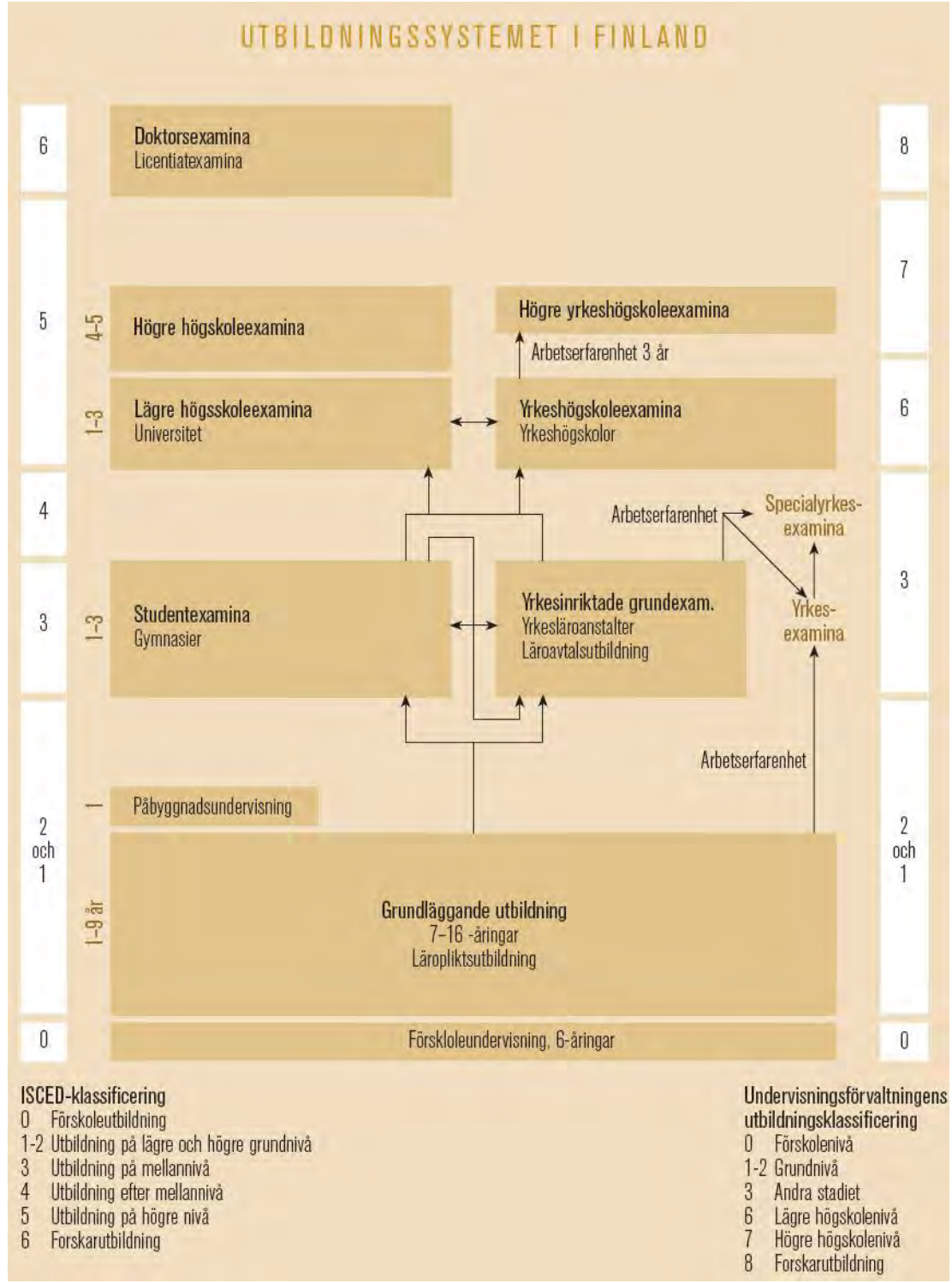

Kilde: http://www.minedu.fi 


\subsection{Oversigt over uddannelsessystemet i Island}

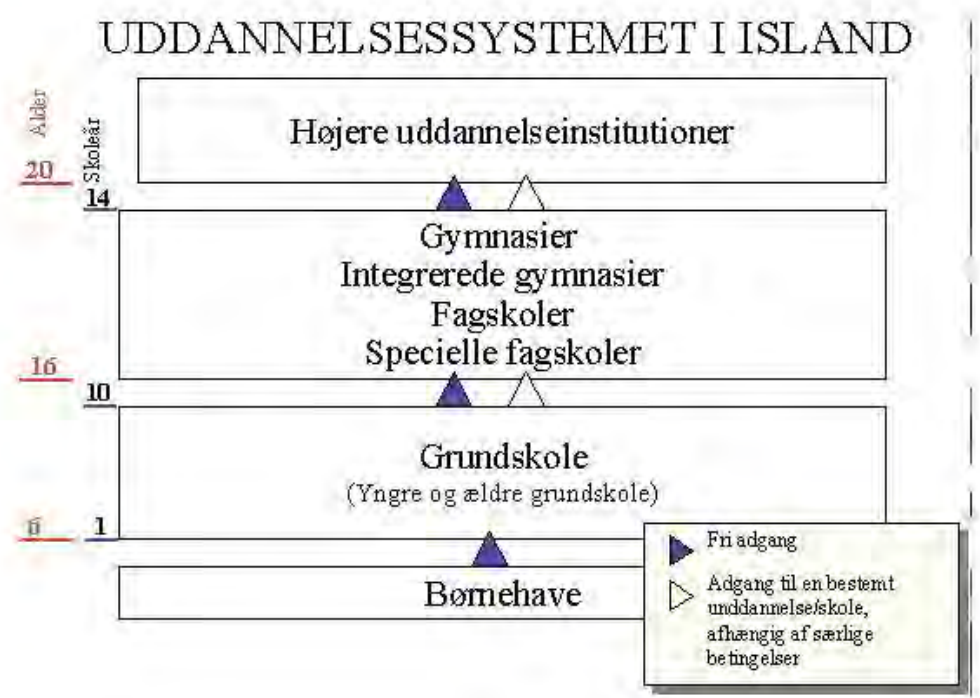

Kilde: http://nor.menntamalaraduneyti.is 


\subsection{Oversigt over uddannelsessystemet i Norge}

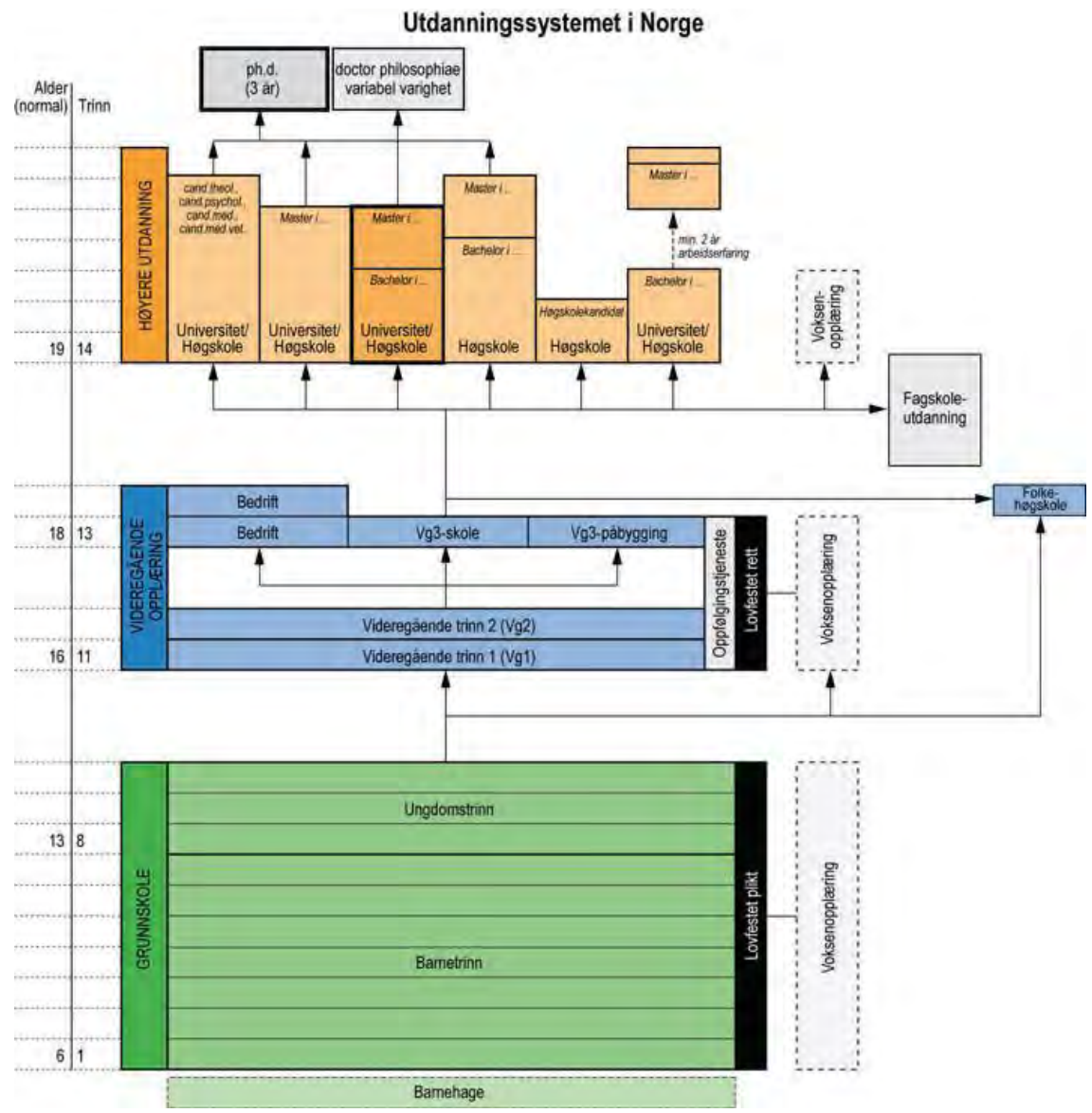

Kilde: Nordisk Ministerråd, 2009. 


\title{
8.6 Oversigt over uddannelsessystemet i Sverige
}

\author{
SVERIGES UTBILDNINGSSYSTEM 2007
}
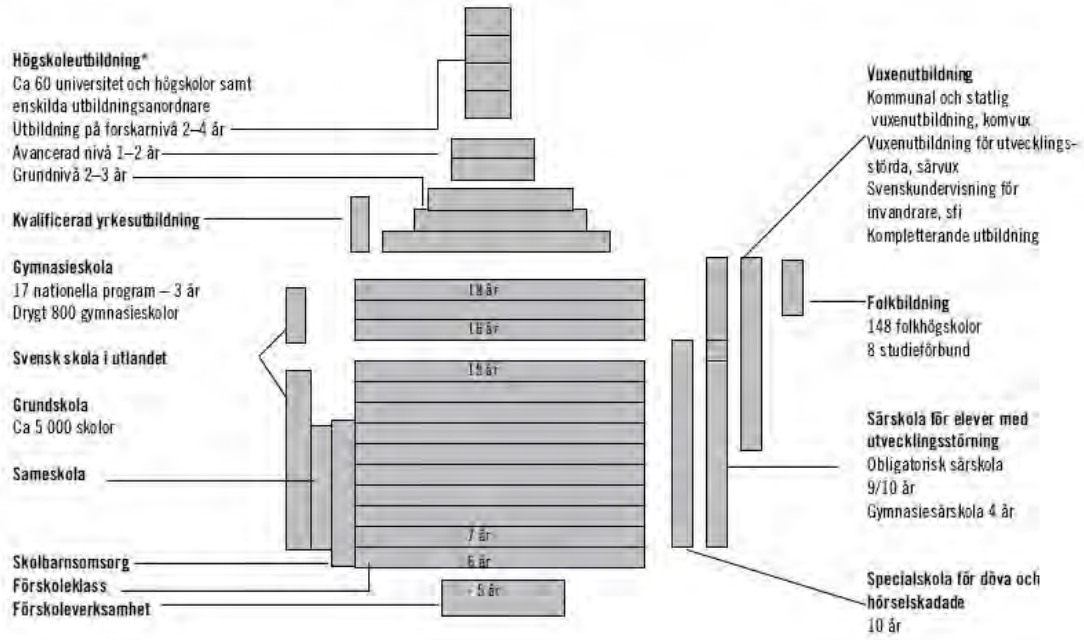

Kilde: Nordisk Ministerråd, 2009. 


\subsection{Oversigt over forkortelser}

\begin{tabular}{|c|c|}
\hline AKKU & Voksenuddannelsesreform initieret I 2007, m.h.p. øget flexicurity; Finland \\
\hline ALL & Adult Literacy and Lifeskills Survey \\
\hline AMO & Arbeidsmarkedsopplæring; Norge \\
\hline AMU & Arbejdsmarkedsuddannelser; Danmark, Finland, Sverige \\
\hline AOF & Arbejdernes oplysningsforbund; Danmark, Island, Norge \\
\hline ASI & Islands st $\varnothing$ rste arbejder-organisation (LO); Island \\
\hline AVU & Almen voksenuddannelse \\
\hline BFU & Betalt frihed til uddannelse \\
\hline BKA & Basiskompetanse i arbeitslivet (kompetenceudviklingsprogram); Norge \\
\hline CERI & Centre for Educational Research and Innovation (forskningsorganisation under OECD) \\
\hline ECON & Internationalt rådgivningsselskab fra Norge \\
\hline $\mathrm{EF}$ & Det Europæiske Fællesskab (efter 1993 EU) \\
\hline EQF & European Qualifications Framework \\
\hline ESF & Den Europæiske Socialfond \\
\hline EU & Den Europæiske Union (før 1993 EF) \\
\hline EUD & Erhvervsuddannelser; Danmark \\
\hline$E \varnothing S$ & Europæisk $\varnothing$ konomisk Samarbejdsområde \\
\hline FA & The Education and Training Service Centre for the Employment Sector; Island \\
\hline $\mathrm{FN}$ & Forenede Nationer \\
\hline FOVU & Nordisk Ministerråds styregruppe for nordisk folkeoplysning og voksenundervisning \\
\hline GVU & Grundlæggende voksenuddannelse; Danmark \\
\hline IALS & International Adult Literacy Survey \\
\hline IDAN & Vocational centre; Island \\
\hline IKT & Informations- og kommunikationsteknologi \\
\hline ILO & International Labour Organization \\
\hline ITIA & Icelandic Tourist Industry Association \\
\hline Komvux & $\begin{array}{l}\text { Kommunal vuxenutbildning, uddannelse for voksne på grundskole- og gymnasieniveau; } \\
\text { Sverige }\end{array}$ \\
\hline KUP & Kompetanseutviklingsprogrammet; Norge \\
\hline LO & $\begin{array}{l}\text { Landsorganisationen, centralorganisation for fagforbund; Danmark, Norge, Sverige (SAK i } \\
\text { Finland, ASI i Island) }\end{array}$ \\
\hline Mennt & $\begin{array}{l}\text { (Educate Iceland) Forum til samarbejde mellem uddannelsessektoren, sociale parter, } \\
\text { kommuner og andre; Island }\end{array}$ \\
\hline NFU & Norsk Fjernundervisning \\
\hline $\mathrm{NHO}$ & Næringslivets Hovedorganisasjon; Norge \\
\hline NORDEK & $\begin{array}{l}\text { Organisationen för nordiskt ekonomiskt samarbete, et ikke-virkeliggjort projekt om et } \\
\text { nordisk fællesmarked }\end{array}$ \\
\hline NOSTE & Voksenuddannelsesprogram, Finland \\
\hline NQF & National Qualifications Framework \\
\hline NVI & Norsk Voksepedagogisk Institutt \\
\hline
\end{tabular}


OECD Organisation for Economic Co-operation and Development

PIAAC Programme for the International Assessment of Adult Competences

SA Confederation of Icelandic Employers; Island

SGS Federation of General and Special Workers in Iceland; Island

SME Small and medium size enterprises

SRV Statens Ressurs- og voksenopplæringssenter; Norge

SVL Rådgivningsgruppen for Nordisk Samarbejde om Voksnes Læring

TE-centraler Arbets- och näringscentraler, statens regionala tjänste- och utvecklingsorganisationer; Finland

UNESCO United Nations Educational, Scientific, and Cultural Organization

VEU Voksen- og efteruddannelse

Vox Nasjonalt fagorgan for kompetansepolitikk, med særlig vekt på voksnes læring; Norge

VUC Voksenuddannelsescentre; Danmark 


\section{Kompetencepolitikkens forudsætninger}

\subsection{Danmark}

Der var i Danmark i 20105.5 mio. indbyggere, hvoraf $9 \%$ var indvandrere eller efterkommere af indvandrere. Med et areal på $43.000 \mathrm{~km}^{2}$, er befolkningstætheden i Danmark på ca. 129 individer $/ \mathrm{km}^{2}$ (Danish Ministry of Foreign Affairs 2010). Danmark er traditionelt et landbrugsland, og landbrugssektoren har spillet en betydelig rolle for dansk økonomi. I den forbindelse har andelsbevægelsen også spillet en væsentlig rolle i organiseringen af forarbejdningen af de mange landbrugsprodukter til eksport (Østergård 2006). Selv om Danmark fra midten af 1960erne udviklede sig til at være et industrisamfund, og betydningen af industrieksporten overhalede eksporten af landbrugsprodukter, spiller landbruget fortsat en væsentlig rolle (Danish Ministry of Foreign Affairs 2010).

Danmark er medlem af EU, og har været det siden 1973. Danmark er desuden medlem af FN siden oprettelsen i 1945, af Nordisk Råd siden det blev etableret i 1952, og af OECD siden 1961.

\subsubsection{Udviklingen af et voksenuddannelsessystem}

Traditionen for voksenuddannelse går i Danmark tilbage til det 17. århundrede i form af kristen undervisning ikke alene for børn og unge, men også for voksne. Voksenuddannelse i form af folkeoplysning blev for alvor en del af det danske uddannelsesbillede med etableringen af den første folkehøjskole i Rødding i 1844. Målet med folkehøjskolen var en kombination af (national) dannelse og undervisning rettet mod arbejdet i landbruget. Siden da har folkehøjskolerne udviklet sig, så der i dag ikke er en relation til landbrugserhvervet. Selv om etableringen af den første folkehøjskole var et privat initiativ, har de danske folkehøjskoler siden 1851 modtaget offentlig støtte. 1800-tallet var også det århundrede, hvor aftenskolerne så dagens lys. I første omgang på landet, men efterhånden bredte 
de sig til byerne, hvor først borgerskabet og senere også arbejderbevægelsen stod bag (Korsgaard 1997; Milana \& Sørensen 2009; OECD 2001a).

1930erne var i Danmark som i store dele af den vestlige verden præget af økonomisk krise og arbejdsløshed. Som led i bestræbelserne på at mindske ungdomsarbejdsløsheden besluttede folketinget i 1933 at give tilskud til, at kommuner og organisationer kunne igangsætte aktiviteter for arbejdsløse i alderen 18-22 år. Aktiviteterne skulle kombinere fysisk arbejde, uddannelse og sport, og deltagerne fik kost og logi imens. I 1940 blev der ligeledes, med ønsket om at bekæmpe ungdomsarbejdsløsheden, oprettet lejre for ugifte unge, der havde været arbejdsløse i to måneder. Nogle af disse lejre blev senere omdannet til skoler for voksne arbejdsløse. Med udviklingen af Danmark til et industrisamfund i 1960erne kom en øget opmærksomhed om behovet for uddannelse af industriarbejderne. Fra 1960 med loven om specialarbejderskoler (fra 1985 AMU-centre) blev uddannelsesvirksomheder formaliseret. Loven indebar blandt andet oprettelse af korte arbejdsmarkedsrelevante kurser for ikke-faglærte arbejdere, og i 1966 fik også faglærte arbejdere adgang til kurser på AMUcentrene (Johanson 2002; Lassen 1998; Lov om tilskud i anledning af ungdomsarbejdsløsheden 1933; Ringsted 2002).

Sideløbende med etableringen af de erhvervsrettede voksenuddannelser, skete der en udbygning af de almene voksenuddannelser. I begyndelsen af det 20. århundrede blev der etableret studenterkurser, der var eksamensforberedende undervisning for privatister til latinskole-eksamen. I 1958 blev der oprettet tekniske forberedelseskurser målrettet unge og voksne. Kurserne, der var organiseret som deltidsuddannelse om aftenen, var en del af en generel styrkelse af de tekniske fag, og havde til formål at kvalificere til optagelse på de mellemtekniske uddannelser. I 1967 blev den højere forberedelseseksamen (hf) introduceret som en mulighed for voksne for at kvalificere sig til at begynde på en videregående uddannelse. I de efterfølgende ti år udviklede kurserne sig væsentligt. Det tekniske sigte forsvandt, og tilbuddet blev udvidet med kurser svarende til niveauet i grundskolens 9. og 10. klasse. Siden 1989 har hf og almen voksenuddannelse (AVU), svarende til grundskolens 9. og 10. klasse, været udbudt som enkeltfag af voksenuddannelsescentrene (VUC) (Klinkby 2004; Undervisningsministeriet 2001b; OECD 2001a). 


\subsubsection{Reformer 1980-2000}

Voksenuddannelsesområdet i Danmark har i løbet af de sidste 30 år været genstand for stor politisk opmærksomhed, og en lang række planer og reformer har set dagens lys. Fælles for de mange reformer er, at der i høj grad har været et ønske om at øge deltagelsen i voksenuddannelse. Men det konkrete fokus for planerne har ændret sig. Hvor der i første del af perioden var et fokus på uddannelse som et gode ikke alene i relation til arbejdsmarkedet, men også for den enkeltes personlige udvikling, er fokus i anden del af perioden langt overvejende på arbejdsmarkedets behov for en veluddannet arbejdskraft ud fra samfundsøkonomiske begrundelser. Den danske udvikling afspejler her en international tendens, hvor fokus i 1970erne lå på retten til uddannelse og den enkeltes personlige udvikling til et fokus på økonomisk konkurrenceevne og beskæftigelse fra omkring midten af 1990erne. Blandt andre Rubenson taler i den forbindelse om første og anden generation af livslang læring (Rubenson 2006).

I 1984 vedtog Folketinget et 10-punkts-program for voksenundervisning og folkeoplysning (Korsgaard 1999). Programmet indeholdt en opfordring til regeringen om „at forbedre rammerne for udviklingen af voksenundervisningen og folkeoplysningen samt øge voksnes muligheder for deltagelse heri." (Folketinget 1984). Som led i implementeringen af programmet blev der blandt andet igangsat en række forsøgs- og udviklingsprojekter. Ligeledes vedtog folketinget i 1989, inspireret af blandt andet ILOs konvention om betalt frihed til uddannelse, Lov om voksenuddannelsesstøtte (Undervisningsministeriet 1989), der havde til formål „gennem tildeling af støtte til voksenuddannelse at skabe økonomisk grundlag for at voksne med kortvarig uddannelse får mulighed for at deltage i uddannelse i arbejdstiden." Voksenuddannelsesstøtten var rettet ikke alene mod erhvervsrettede kurser og uddannelser, men også mod almen kompetencegivende voksenuddannelse og folkeoplysning. Dette var i overensstemmelse med det daværende officielle mål med voksenuddannelse i Danmark, der både skulle tjene arbejdsmarkedets og den enkelte voksnes interesser (OECD 2001a). Loven indebar dog ikke en automatisk ret for kortuddannede til at deltage i uddannelse i arbejdstiden, da det for beskæftigede fortsat krævede arbejdsgiverens accept. De kortuddannedes mulighed for at få økonomisk støtte til at deltage i uddannelse i arbejdstiden indebar ikke alene en stigning i interessen for at deltage i uddannelse, men også en stigning i den faktiske deltagelse (Larson 1994). 
En anden følge af 10-punkts-programmet var en ændring af læreplanen for den almene voksenundervisning, der hidtil havde været identisk med den, der var gældende i grundskolens 8.-10. klasse. Med Lov om almen voksenundervisning fra 1989 blev der indført en særlig læreplan tilpasset voksne (OECD 2001a).

I den nytiltrådte centrum-venstreregerings grundlag „En ny start“ fra 1993 blev der lagt op til at etablere 60.000 nye voksen- og efteruddannelsespladser og at øge efterspørgslen efter voksen- og efteruddannelse. Som led i implementeringen af planen introducerede regeringen et "taxameter"-system for finansieringen af voksen- og efteruddannelserne, hvor tilskuddet til uddannelsesinstitutionerne blev gjort afhængigt af gennemstrømningen af studerende, samt nye regler for uddannelsesorlov. Reformen indebar en betragtelig forøgelse i voksen- og efteruddannelsesaktiviteten (Arbejdsministeriet, Undervisningsministeriet \& Finansministeriet 1999; OECD 2001a).

I 1999 præsenterede Arbejdsministeriet, Undervisningsministeriet og Finansministeriet i fællesskab rapporten „Mål og midler i offentligt finansieret voksen- og efteruddannelse." Det forhold, at arbejdsgruppen bag rapporten blev ledet af Finansministeriet er en indikation af det tidligere omtalte skifte i fokus for voksenuddannelsespolitikken i Danmark. Voksenuddannelse var således nu i høj grad et økonomisk og arbejdsmarkedspolitisk redskab. I introduktionen til rapporten fremhæves da også den formodede sammenhæng mellem voksenuddannelse på den ene side og øget beskæftigelse på den anden side (Arbejdsministeriet, Undervisningsministeriet \& Finansministeriet 1999). Rapporten medførte blandt andet en reform af voksenuddannelsessystemet i 2001 (Mailand 2009).

Som en af de sidste reformer inden for uddannelsesområdet i det 20. århundrede, etableredes i 2000 med Lov om åben uddannelse (Undervisningsministeriet 2000) videreuddannelsessystemet for voksne. Det blev i loven fremhævet, at uddannelserne skulle tilrettelægges på en måde, der tog hensyn til „voksnes praktiske muligheder for at kombinere uddannelse og tilknytning til arbejdsmarkedet" (Undervisningsministeriet 2000). Dette system omfatter ikke alene grundlæggende almene og erhvervsrettede uddannelser, men også uddannelser organiseret som åben uddannelse ved de videregående uddannelsesinstitutioner. Systemet beskrives i en rapport fra Undervisningsministeriet fra 2001 på følgende måde: 


\begin{abstract}
„De ordinære uddannelser består af ungdomsuddannelserne på gymnasialt niveau eller erhvervsuddannelsesniveau (EUD) med de ordinære videregående uddannelser på 3 slutniveauer som den uddannelsesmæssige forlængelse. Tilsvarende findes voksenuddannelser på ungdomsuddannelsesniveau, f.eks. hf eller grundlæggende voksenuddannelse (GVU), og i forlængelse heraf 3 videregående uddannelsesniveauer, der er parallelle til de ordinære uddannelsesniveauer. Masteruddannelserne svarer således til kandidatniveau på de lange videregående uddannelser, diplomuddannelserne til bachelorniveau på de lange videregående uddannelser samt afslutningsniveauet for de mellemlange videregående uddannelser, og VVU svarer til niveauet på de korte videregående uddannelser“
\end{abstract}

(Undervisningsministeriet 2001a, s. 21).

\title{
9.2 Finland
}

Befolkningstallet i Finland er stigende og er p.t. ca. 5,4 million. Finland havde, da den økonomiske krise toppede omkring 1969-70, nogen udvandring men har nu indvandring. Den er dog foreløbig begrænset: Ca. 2,5\% af befolkningen er indvandrere. I store dele af landet er bebyggelsen spredt, og den økonomiske vækst sker først og fremmest i de sydlige regioner. Den finske befolkning har siden krigene med Rusland (1939-44) oplevet store omvæltninger politisk, socialt og økonomisk. I 1950erne dominerede landsbrugsøkonomien, og Finland sprang i løbet af få årtier til en vidensøkonomi, der er baseret på forskning og højteknologi og har siden 1970erne scoret højt i de fleste former for ranking.

Finland blev medlem af FN 1955, af Nordisk Råd 1955, af OECD 1969, af EU 1995 og gik i 1999 over til Euro som møntfod. Finland er dermed en del af Eurozonen.

\subsubsection{Udviklingen af et voksenuddannelsessystem}

De folkeoplysende aktiviteter opstod under det russiske overherredømme (1809-1917) og var præget af en tænkning i nationalitet og kultur. Den første folkehøjskole blev grundlagt i 1889 og det første arbejderinstitut (det der i dag betegnes medborgerinstitut) i 1899. Arbejderinstitutter og folkehøjskoler efter dansk forbillede var de vigtigste institutionsformer, 
og traditionen er stadig levende. Finske sociologer har registreret en generel interesse for dygtiggørelse og gør opmærksom på, at den voksne del af befolkningen har meget forskellige forudsætninger.

Selv om erhvervsuddannelsesinstitutionernes aftenkurser har en længere historie, kan man sige, at voksenuddannelse startede efter 1966, da der blev etableret erhvervskursuscenternetværk for at forbedre de arbejdsløses kundskaber. Da Finland i 1971 beslutter sig for at få udviklet en selvstændig politik for uddannelsen af voksne, vælger regeringen at gøre dette gennem et langvarigt kommissionsarbejde. Kommissionens undersøgelser fører i 1976 til opstillingen af fire grundlæggende mål for det nationale udbud af voksenuddannelse:

- at øge den uddannelsesmæssige lighed

- at fremme produktionen - udvikle de erhvervsmæssige færdigheder

- at fremme demokratiet - udvikle beredskab for medvirken i samfundslivet

- at udvikle kulturen - at udvikle personligheden (Mørch Jacobsen, 1982)

Hovedvægten lægges på samfundsmæssig retfærdighed og økonomisk vækst, og de mål, der traditionelt forbindes med folkeoplysende virksomhed, er placeret som tredje og fjerde prioritet. Den økonomiske krise medfører, at den socialdemokratiske regering vælger at satse på at få Rigsdagen til at vedtage en lovgivning om arbejdsmarkedsuddannelser (Mørch Jakobsen 1982). Ganske vist vedtages der i 1980 en lov om betalt frihed til uddannelse (BFU), men da der ikke afsættes midler til lønkompensation, får denne lovgivning ingen effekt.

\subsubsection{Reformer 1980-2000}

Målet om „at fremme produktionen - udvikle de erhvervsmæssige færdigheder" blev Finlands førsteprioritet, og dette indebar, at to tredjedele af det sparsomme statsbudget til uddannelse af voksne gik til erhvervsrettet uddannelse (Mørch Jacobsen 1982). Denne nationale strategi blev i slutningen af 1980erne yderligere understøttet af de samfundsmæssige hensyn, der måtte tages i kølvandet på Sovjetunionens sammenbrud. Arbejdsløsheden steg til dramatiske højder, og den socialdemokratiske regering gik af. Trepartsforhandlinger baseret på en ny „social pagt“ blev afgørende 
for samfundsudviklingen, og det var en national samlingsregering (199599), der styrede Finland ind i eurozonen (Elvander 2002).

Som EU-land var Finland dengang det nordiske land, der mest helhjertet arbejdede for integration, og det er stadig tilfældet. Princippet om livslang læring for alle har været grundlaget for finsk uddannelsespolitik siden „Guldtavlerne i græsset" (Nordisk Ministerråd 1995), og Finlands engagement i „European Year of Lifelong Learning“ (1996) var uden forbehold. Det var endvidere vigtigt for Finlands engagement, at livslang læring også stod højt på OECDs dagsorden, blandt andet i form af OECDs Lifelong learning for All fra 1996. Året efter offentliggjorde Finland „The Joy of Learning: a national strategy for lifelong learning“ (Ministry of Education 1997).

Teksten byggede på et omfattende udvalgsarbejde. Regeringen havde udpeget repræsentanter for Undervisningsministeriet, Arbejdsministeriet, Rigsdagen, forskningen, medierne, virksomhederne og fagforeningerne til at formulere en strategi, der kunne opnå tilslutning fra alle parter. Deres forslag, der blev godkendt af regeringen, lagde op til en udvikling af grundskolen og til en øget indsats for at styrke elevernes motivation. I forhold til de voksne foreslog udvalget at udvikle grundlæggende færdigheder og relevante kompetencer i forhold til voksnes liv i et informationssamfund. Karakteristisk for „The Joy of Learning“ er det brede sigte og inddragelsen af arbejdslivet og civilsamfundet. Satsningen på informationsteknologi og på vejledning var fornyende elementer i denne strategi, der stemte overens med den korporative tilgang, der prægede arbejdsmarkedspolitikken.

\subsection{Island}

Island har været en selvstændig stat siden 1944. Pr. 1. januar 2011 havde landet godt 300.000 indbyggere, hvoraf 8,1\% var indvandrere (Statistics Iceland 2011). Med et areal på $103.000 \mathrm{~km}^{2}$ giver det en befolkningstæthed på ca. 3 pr km².

Island har været medlem af Nordisk Råd siden oprettelsen i 1961. Island har desuden været medlem af FN siden 1946 og af OECD siden 1961. Siden 1970 har Island været medlem af EFTA og fra 1994 af EØS. Der pågår p.t. forhandlinger mellem Island og EU om islandsk EU-medlemskab. 
De islandske modeller for udvikling og implementering af tilbud til voksne bygger overvejende på nationale erfaringer. Dette betyder ikke, at man har været uinteresseret i de modeller, der er udviklet i nordiske og europæiske lande. Islændingene synes at være meget udadvendte på dette område, men de modeller, der har vist sig at være effektive, er dem, hvor landet er gået egne veje. I 1992 vedtog Altinget et lovforslag om voksnes uddannelse samt et lovforslag om arbejdsmarkedsuddannelse, der ligner lovgivningen i de øvrige nordiske lande, men ingen af dem blev ført ud i livet (interview med det islandske embedsværk 7.-8. april 2010).

Island har siden oprettelsen af Nordisk Ministerråd i 1971 deltaget aktivt i en række nordiske projekter vedrørende voksnes læring og har som OECD-land leveret data til en række komparative undersøgelser. Som EØS-land har Island en aftale med EU, der på uddannelsesområdet giver Island de samme pligter og rettigheder som medlemslandene. Dette har medført islandsk deltagelse i et stort antal projekter under EUs uddannelsesprogrammer. Inden for ungdomsuddannelserne oplevede Island gennem mange år et stort frafald, hvor omfanget var dobbelt så stort som i de øvrige nordiske lande. Dette mønster forklares oftest som „kulturelt.“ Dvs. betinget af de vilkår, der gælder for de traditionelle erhverv, men omfanget steg også pga. en generel efterspørgsel efter arbejdskraft. Af denne grund har 31 \% af de 25-64-årige på det islandske arbejdsmarked ingen formel erhvervsmæssig uddannelse (2005). Der er derfor god mening i at sætte ind med foranstaltninger i forhold til kortuddannede, og Island har især satset på at få anerkendelsen af voksnes realkompetence sat i system på en effektiv måde.

\subsubsection{Udviklingen af et voksenuddannelsessystem}

Folkeoplysningstraditionen er gammel og rodfæstet og har udviklet sig uden tilskudslove. De foreninger, der udbyder folkeoplysende aktiviteter, har oftest været selvfinansierende, men staten har i mange tilfælde ydet tilskud, når foreningerne har henvendt sig. Reykjavik Kommune oprettede et voksenundervisningscenter i 1940, og det fremgår af en undersøgelse fra 1982, at 20 kommuner dengang drev skoler for voksne (Nordisk Ministerråd 1982). Folkehøjskolen har gammel hævd i Island, og i 1977 fik skoleformen sin egen tilskudslov. Også AOF har under skiftende navne spillet en væsentlig rolle. 


\subsubsection{Reformer før 2000}

Det er karakteristisk, at der siden 1974 har været fremlagt en række lovforslag om uddannelse af voksne, men selv om Altinget har vedtaget to af dem, har regeringen ikke implementeret lovgivningen fuldstændigt. Det gælder først og fremmest loven om voksenuddannelse fra 1992 (interview med det islandske embedsværk 7.-8. april 2010). Loven, der i høj grad byggede på de øvrige nordiske landes erfaringer, var bureaukratisk ifølge den daværende regering, og man kan da også pege på, at allerede i 1970erne blev mange uddannelsestilbud til voksne udviklet og organiseret af arbejdsgiver- og arbejdstagerorganisationer og ofte med tilskud fra andre ministerier end Undervisningsministeriet. De mest kendte eksempler er efteruddannelsestilbud til fiskere og elektrikere. I 1972 fik gymnasiet i Reykjavik lov til at oprette klasser for voksne, og denne model er siden blevet udviklet. I 1996 ved revisionen af ungdomsuddannelserne fik disse statslige institutioner - der i Island kombinerer det almene sigte med det erhvervsmæssige - mulighed for at optage voksne. På universitetsområdet synes den islandske model at virke godt, idet andelen af universitetsuddannede, er højere end OECD-landenes gennemsnit.

\subsection{Norge}

Befolkningstallet udgør ca. 4.8 millioner i 2009, og Norges andel af indvandrere og børn af indvandrere (personer med begge forældre født uden for Norge) er ca. $16 \%$. Statens styring af uddannelsessystemet er markant, og de 19 fylker og 431 kommuner er uddannelsesudbydere. Naturforholdene gør, at store dele af befolkningen bor spredt, hvilket kan forklare, hvorfor brevskole (nettskoler) havde stor gennemslagskraft, før radioen og andre medier tog over.

Norge er i lighed med Island medlem af EFTA og EøS. Norge var således i 1960 med til at etablere EFTA, og var i 1992 blandt medunderskriverne af EØS-aftalen, der trådte i kraft 1994. Norge har ligesom Danmark og Island været medlem af Nordisk Råd siden oprettelsen i 1952. Landet er desuden medlem af FN siden 1945, og af OECD siden 1961. 


\subsubsection{Udviklingen af et voksenuddannelsessystem}

Folkehøjskolebevægelsen, afholdsbevægelsen, nynorskbevægelsen (norskdomsrørsla) og ungdomsbevægelsen var de første initiativtagere inden for folkeoplysende virksomhed. De første organisationer blevet etableret i sidste halvdel af forrige århundrede, det gælder blandt andet Selskapet til Folkeopplysningens Fremme som blev stiftet allerede i 1851, studentenes forening for fri undervisning i 1864, mens arbejderakademierne kom i midten af 1880erne og Norges Ungdomslag i 1896. Fra 1918 fik afholdsbevægelsen IOGT også statsstøtte. Arbejdernes Oplysningsforbund (AOF) oprettedes i 1931 og blev hurtigt en landsdækkende aktør, og derefter opstod en række mindre organisationer, der efter en konsolideringsperiode blev anerkendt af departementet som modtagere af statstilskud. I mellemkrigstiden var der imidlertid en årrække, hvor staten ikke ydede nogen form for tilskud, og det var en af grundene til, at de folkeoplysende organisationer fandt sammen i et fællesorgan (Samnemnda for studiearbeid), der fungerede som en ramme for forhandlinger med statsmagten. I 1946 skiftede nævnet status og blev til „Statens Folkeoplysningsråd.“

I 1960erne var hele uddannelsessystemet i ekspansion, og allerede fra 1958 blev der organiseret offentlig arbejdsmarkedsuddannelse (AMO) for voksne. En socialdemokratisk regering varslede i 1965 via en „stortingsmelding", at offentlig voksenuddannelse var under planlægning, og samme år blev Statens Folkeoplysningsråd nedlagt og erstattet af „Statens Voksenopplæringsråd." Hovedargumenterne i stortingsmeldingen var den teknisk-økonomiske udvikling og de nye krav på arbejdsmarkedet. Desuden blev det anført, at forældregenerationen havde savnet de mange gratis uddannelsesmuligheder, som de unge nu fik adgang til. Dvs. retfærdighed var et argument. Der kom imidlertid til at gå en årrække, før uddannelsen af voksne blev et anliggende for det offentlige uddannelsessystem, og i 1970erne blev hovedargumenterne udvidet med behovet for (fordelingspolitisk) ligestilling, demokrati og personlig vækst. Udviklingen i Norge var i samklang med diskussionerne på UNESCOs verdenskonferencer: På konferencerne i 1949 (Helsingør) og i 1960 (Toronto) satte delegationerne deres lid til den frivillige sektor, men på konferencen i 1972 (Tokyo) var regeringerne, der spillede ud, og Norge blev det første europæiske land, der fik lovgivet i overensstemmelse med de planer, der blev fremlagt i Tokyo. Sigvart Tøsse (2005) nævner, at både „livslang læring“ (UNESCO) og „tilbagevendende uddannelse“ (OECD) kan efterspores i denne tidlige lovgivning. 
„Lov om Voksenopplæring“ (Kunnskapsdepartementet 1976) skelnede ikke mellem almen og erhvervsrettet uddannelse og var en relativ bred lov, der gav plads til udbydere fra de frivillige organisationer og fra de offentlige uddannelsesinstitutioner. Tre år efter 1976-lovens ikrafttræden var Norges budget for voksnes uddannelse blevet firdoblet, og voksenuddannelse var blevet til et selvstændigt område inden for uddannelsessystemet. Den offentlige styring af det nye område blev tredelt: Staten, fylkerne og kommunerne havde fåt opgaver. Fylkerne fik ansvar for voksenuddannelse på videregående niveau, mens kommunerne tog sig af det grundlæggende niveau. En direkte følge af loven var oprettelsen af Norsk Voksenpedagogisk Institutt (NVI), der blev placeret i Trondheim, og Norsk fjernundervisning, der blev placeret i Oslo.

\subsubsection{Reformer 1980-2000}

En længere periode med arbejdsløshed satte i 1980erne en stopper for udviklingen af det offentlige almene uddannelsestilbud til voksne. De frivillige studieforbund og deres medlemsorganisationer fortsatte deres virksomhed som tidligere, men deltagerantallet faldt støt, blandt andet som følge af faldende statsstøtte. Det blev i stedet AMO-systemet, der ekspanderede, og i midten af dette årti modtog AMO dobbelt så mange offentlige midler som de folkeoplysende organisationer. I begyndelsen af 1990erne var forholdet mellem statstilskuddene til folkeoplysende og erhvervsrettet uddannelse blevet 1:10. De folkeoplysende organisationers udbud var stagnerede pga. offentlige nedskæringer, mens virksomhedernes interne opkvalificering var i vækst. Dette forhold blev fremhævet af regeringen i en stortingsmelding om „Utdanning og arbeid“ (Barne-, likestillings- og inkluderingsdepartementet 1981), hvor arbejdslivet blev betragtet som „det tredje senter for læring." En senere statistisk unders $\emptyset$ gelse viste, at antallet af voksne i virksomhedsintern uddannelse var 3-4 gange højere end antallet af voksne i de uddannelsestilbud, der blev tilrettelagt i fritiden (Tøsse 2005).

OECD havde i 1989 gjort opmærksom på, at medlemslandenes uddannelsespolitik ikke harmonerede med deres økonomiske politik, og på det tidspunkt havde Norge lagt kursen om. Regeringen havde i 1981 nedsat et udvalg, der skulle udarbejde planer for „livslang læring for alle“ (forstået som fordelingspolitik), men da betænkningen udkom i 1986, ønskede regeringen ikke at realisere forslagene. Norge satsede på „kompetan- 
seutvikling“, og der er klar overensstemmelse mellem betænkningen „Med viten og vilje" (Norges offentlige utredninger 1988) og en stortingsmelding (1989), der blev kaldt „Mer kunnskap til flere“ (Kirke- og undervisningsdepartementet 1989). Sociologen Gudmund Hernes blev i 1990 udnævnt til undervisningsminister og fik gennem sin ministerperiode revideret lovgivningen på alle niveauer. Hovedargumentet bag skiftet var de udfordringer, som globaliseringen ville udløse. Den økonomiske kappestrid mellem nationalstaterne medførte ifølge Gudmund Hernes, at alle talenter i befolkningen måtte udvikle deres kompetencer. Departementets afdeling for „voksenopplæring og folkeopplysning“ skiftede navn til „,voksenopplæring og utdanningsfinansiering."

I 1991 ændrede både Norge og Sverige politik i forhold til de folkeoplysende organisationer. Den norske reform ændrede ved organisationsstrukturen inden for det, der nu blev kaldt „den tredje sektor“ eller „civilsamfundet." Efter forhandlinger med organisationerne blev der indgået en aftale, der indebar, at antallet af folkeoplysende aktører ville blive reduceret til det halve. For de mindre organisationer betød dette, at hvis de ønskede at fastholde deres folkeoplysende virksomhed, måtte de i løbet af en overgangsperiode, der blev sat til fem år, fusionere med andre organisationer og danne et „studieforbund“, eller gå ind i allerede eksisterende studieforbund. Den politiske argumentation for den folkeoplysende virksomhed blev ved denne lejlighed udvidet med det samfundsmæssige behov for udvikling af „,social capital“ (Tøsse 2005).

Det blev fagbevægelsen (LO), der kom til at tage det første afgørende skridt mod en norsk „kompetansepolitikk.“ På LOs kongres i 1993 var kompetenceudvikling blevet gjort til et strategisk mål, og året efter accepterede arbejdsgiverne (NHO), at der blev indsat et kapitel om kompetenceudvikling i parternes hovedaftale. I forbindelse med udviklingen af „Kompetansereformen“ som Stortinget vedtog i 1999, fremgik det af udvalgets betænkning (1997), at statens investering i kompetenceudvikling kun udgjorde $20 \%$ af de investeringer, som de private virksomheder foretog, og dette forhold illustrerede, hvordan de norske virksomheder reagerede på den internationale udfordring. Da staten øgede sine investeringer, skete det i et tæt samarbejde med arbejdsmarkedets parter. Under implementeringen af reformen blev der dannet et nationalt "forum" for at sikre en løbende koordination, og arbejdsmarkedets parter oprettede et fællessekretariat (Payne 2006). 
Der var ikke tale om en uddannelsesreform, men om en „arbejdslivsreform." Det var medarbejdernes vilkår, der blev reguleret på en ny måde, og årsagen til den politiske velvilje var ønsket om at sikre sig mod en storkonflikt på arbejdsmarkedet (Payne 2006). Stortinget gav arbejdstagerne nogle nye rettigheder i forhold til kompetenceudvikling, blandt andet ret til grundskole, ret til videregående oplæring, og til dokumentation af realkompetencer. LOs hovedkrav om løn under uddannelsesorlov blev dog ikke accepteret. Stortinget tilsluttede sig tanken om at udvikle et nationalt system for dokumentation af realkompetencer, der skulle gøre det muligt, at voksne med relevante kompetencer kunne få deres ophold i det formelle uddannelsessystem forkortet. Med ordningen blev også mulighederne for alternativ optagelse på universitetet og høgskoler, samt en bredere tilgang til arbejdsmarkedet, udviklet. Regeringen, der ønskede at sikre freden på arbejdsmarkedet, tilbød desuden arbejdsmarkedets parter op til 400 millioner NOK til udviklingsprojekter, der kunne bidrage til at gøre arbejdspladserne til „læringsarenaer" og sikre skabelsen af et marked for kompetenceudvikling. Det blev til „Kompetanseutviklingsprogrammet.“

(KUP) som blev styret av parterne i arbejdslivet. I 2001 under implementeringen af Kompetansereformen fik departementets afdeling for uddannelse og studiefinansiering et nyt navn. Det blev nu til „Avdeling for kompetanse og arbeidsliv“ (Tøsse 2005) Avdeling for kompetanse og arbeidsliv" blev nedlagt i 2005 og arbejdet blev integreret i øvrige afdelinger i departementet. Dvs. policy-begrebet „voksenopplæring“, som en socialdemokratisk regering havde indført som et supplement til policy-begrebet „folkeopplysning“, blev anset for at være irrelevant. Voksenuddannelsespolitik var blevet til kompetence-politik.

\subsection{Sverige}

Sveriges befolkning uppgår till knappt 9,4 miljoner invånare (juli 2010) fordelt på $450.000 \mathrm{~km}^{2}$. Befolkningstätheten är låg med koncentration till den södra tredjedelen av landet. Urbaniseringen har pågått oavbrutet sedan 1920- och 30-talen. Invandringen tog fort mot slutet av 1960-talet med en ganska betydande arbetskraftsinvandring. Under de senaste decennierna är det i huvudsak flyktingar och anknytningsfall som invandrat. 
Sverige blev medlem av EU 1995. Sverige er desuden medlem af FN siden 1946, og af OECD siden 1961. I lighed med Danmark, Norge og Island, har Sverige været medlem af Nordisk Råd siden etableringen i 1952.

\subsubsection{Utvecklingen av ett vuxenutbildningssystem}

Den svenska utbildningspolitiken växer fram från 1800-tal fram till 1960.

Etableringen av formaliserad vuxenutbildning i Sverige sätts ofta i samband med jordbrukarnas behov av utbildning och sådan kompetens att de kunde delta i det nya kommunala självstyret. Bakgrunden var dels nya kommunallagar 1864, dels tvåkammarriksdagens införande 1866. Bygemenskap hade sedan tidigare lösts upp genom en genomgripande skiftesreform. Självhushållningen inom jordbruket började sakta ersättas av marknadsekonomi. Antalet självägande bönder minskade successivt, men de som fanns kvar fick allt större enheter att bruka. Industrialiseringen i Sverige intensifierades runt sekelskiftet 1800/1900.

Redan 1868 grundades de första folkhögskolorna. Expansionen av skolan var till viss del ett sätt att utveckla såväl individ som samhälle (Runesdotter 2010), men framförallt ett sätt att möta genomgripande samhällsförändringar (Thång 2006). Under 1900-talets första decennier växte studieförbund och studiecirklar fram. Redan 1898 grundande Nils Svensson Hermod Sveriges första korrespondensinstitut efter brittisk förebild. Ända fram till mitten av 1960-talet var korrespondensstudier den vanligaste formen för behörighetsgivande vuxenstudier. Ett permanent problem var dock de höga avbrotten.

Första gången staten gick in mer aktivt i vuxenutbildningen var 1938 genom Statens aftonskola, som skulle möjliggöra för studiebegåvande vuxna att avlägga studentexamen. Statens engagemang för vuxenutbildning var dock mycket begränsat fram till 1960-talet (Henning-Loeb 2007; Thång 2006). Något studiefinansiellt stöd fanns ännu inte. Vad som också kan vara värt att nämna är den kursverksamhet som startades som en folkbildningsverksamhet på olika universitetsorter under 1930-talet. År 1942 samordnades denna verksamhet under namnet Folkuniversitetet.

Det förslag om gymnasier för vuxna som framförde av 1946 års skolkommission (SOU 1948, s. 27) kom inte att genomföras, men senare utredningar påpekade kraftfullt vikten av att möjliggöra tillträde för vuxna till högre utbildning. Bland annat startades kvällsgymnasier av några studieförbund i de större städerna. Det första tillkom år 1953 i Stockholm. 
Verksamheten var dock inte statsunderstödd, utan finansierades genom deltagaravgifter. Det omedelbara motivet för kvällsgymnasierna var en förändring av universitetsbestämmelserna, som innebar att tillträde till universitetsstudier kunde medges utan studentexamen, om man hade betyg i ett begränsat antal ämnen.

De övergripande målen för en framtida vuxenutbildning formulerades idémässigt av 1946 års skolkommission (SOU 1948, s. 27), som hade uppmärksammat behovet av kompetensinriktad utbildning för vuxna. Tiden för en mer genomgripande reformering av vuxenutbildningen var emellertid ännu inte mogen under 1950-talet. De ekonomiska resurserna var därtill alltför begränsade.

1960-talets svenska arbetsliv kännetecknades också av en betydande strukturomvandling i näringslivet. Mindre lönsamma företag skulle tvingas att rationalisera, eller rent av gå i konkurs, varvid arbetskraften skulle föras över till expanderande företag genom en aktiv arbetsmarknadspolitik. Det handlade om att förstärka näringslivets produktivitets- och konkurrenskraft (Simonson 1988). Detta var huvudskälet till den kraftiga utbyggnaden av arbetsmarknadsutbildningen (AMU-center) som inleddes under början av 1960-talet. Arbetsmarknadsutbildningen var entydigt inriktad mot arbetsmarknad och olika yrken, och denna vuxenutbildningsform integrerades medvetet inte i det formella utbildningssystemet, trots att den enhetliga gymnasieskolan inkluderade yrkesutbildningarna.

De utredningar som under 1960-talet drev vuxenutbildningsfrågorna starkast i Sverige var den studiesociala utredningen (SOU 1962, s. 5), gymnasieutredningen (SOU 1965, s. 60) och yrkesutbildnings-beredningen (SOU 1966, s. 3). Samtliga dessa utredningar argumenterade för vuxenutbildning utifrån det snabbt föränderliga samhället, den ökade kunskapsmassan och näringslivets strukturomvandling. Det var den vuxenpolitiska delegationen inom den studiesociala utredningen som drev vuxenutbildningsfrågorna (Larsson 2003). Staten involverade sig alltmer i frågan om vuxenutbildningen. Den politiska ambitionen var kompensatorisk. De som inte fått så mycket utbildning i ungdomsskolan skulle nu få en andra chans. Sociala, ekonomiska och geografiska aspekter skulle inte behöva utgöra grunden för utbildningsmässiga orättvisor. Unga vuxna i avsaknad av gymnasieutbildning var en viktig målgrupp. Det övergripande motivet var att förse arbetsmarknaden med välutbildad arbetskraft (Rubenson, Tuijnman \& Wahlgren 1999; Lumsden Wass 2004). 
Vuxenutbildningens huvuduppgift var att tillgodose arbetsmarknadens behov och efterfrågan på utbildad arbetskraft. Här formades och konkretiserades idébakgrunden och motiven för den kraftiga utbyggnaden av vuxenutbildningen i och med 1967 års reform om kommunal vuxenutbildning. Detta var en ny behörighetsgivande och avgiftsfri utbildning för vuxna. Kommunerna blev huvudmän för den kommunala vuxenutbildningen (Komvux) och övertog därmed ansvaret från studieförbundens kvällsgymnasier. Sammanfattningsvis kan man konstatera att vuxenutbildningens starka institutionalisering genom 1967 års reform var en direkt följd av efterkrigstidens omfattande reformering av ungdomsskolan, med rötter i humankapitalismen och med kvällsgymnasierna som förebild.

1970-talet innebar en radikalisering av utbildningspolitiken. Vuxenutbildningen expanderade och målen diskuterades (Ahlén 1985). Det var ett årtionde som präglades dels av oljekrisen 1973, dels av en expansiv och kostnadskrävande välfärdspolitik. En lång period av högkonjunktur avklingade, med kraftigt stigande arbetslöshet och konflikter på arbetsmarknaden. Den utbildningsoptimism som präglat 1960-talet förbyttes mot pessimism. Utbildning framstod inte längre entydigt som lösningen på arbetslivets och samhällets alla problem. 1967 års reform uppfattades som elitistisk, och innebar att stora grupper med kort och bristfällig utbildning inte kom i åtnjutande av de nya möjligheterna till vuxenutbildning. Vuxenutbildningspolitiken radikaliserades, och kom att alltmer inriktas mot resurssvaga grupper i samhället. Utbildningsklyftor skulle överbryggas och demokratin skulle stärkas. Den viktigaste vuxenutbildningsrefomen under decenniet lades fram 1975 (Utbildningsdepartementet 1975, s. 23). Återkommande utbildning skulle underlättas och vuxenutbildningen skulle bidra till de studerandes personlighetsutveckling. Individens ställning på arbetsmarknaden skulle stärkas och de kortutbildades behov av överbryggande utbildning skulle tillgodoses. Återkommande utbildning, som blev ett begrepp i 1968 års utredning om högskolan (SOU 1973, s. 2). Begreppet återkommande utbildning definieras av OECD:s forskningsorganisation CERI 1973.

Reformer under 1970-talet gav arbetstagare rätt till ledighet för studier, och ett särskilt vuxenstudiestöd infördes. Detta förändrade vuxenutbildningens förutsättningar och stärkte kommunerna som anordnare av vuxenutbildning. (Fransson \& Lunquist 1988; Johansson \& Salin 2007). En debatt om livslångt lärande hade inletts under 1960- och 70-talen. Den bärande tanken var återkommande utbildning. Begreppet diskuterades redan av universitetsutredningen om återkommande utbildning (SOU 1959, s. 45; 
SOU 1973, s. 2), som en principlösning för vuxenutbildning. Alternering mellan arbete och utbildning skulle möjliggöras. Strategin innebar att en omfördelning av utbildningsresurserna. En förlängd ungdomsutbildning ansågs inte ge de effekter man önskade, varför ökade anslag till vuxenutbildning och den högre utbildningen var att föredra. Även om U 68 inte kom att få något större genomslag, så var idén ett sätt att åstadkomma en bättre anpassning mellan arbetsmarknadens behov och utbildningssystemets produktion. Genom att möjliggöra återkommande utbildning, skulle utbildningsvalet inte få samma livsavgörande betydelse som under tidigare decennier. Avsikten var inte att förlänga människors sammanlagda utbildningstid, utan den skulle fördelas under livscykeln.

\subsubsection{Reformer 1980-2000}

I rapporten „Formell vuxenutbildning - utveckling och förutsägelser“ (Johansson \& Salin 2007) konstaterar författarna - två ledande profiler inom svensk vuxenutbildning under 1970- och 1980-talen - att Komvux av OECD-granskare i början av 1990-talet kallades för ,juvelen i kronan.“

Komvux, en vuxenanpassad kopia av ungdomsskolan, statligt reglerad och till stora delar statligt finansierad men decentraliserad med kommunerna som huvudmän, saknade motsvarighet på andra håll i världen. Ett par hundra tusen studerande i alla åldrar hade ett vuxenutbildningssystem med ett utbud som omspann allt från alfabetisering och svenska för invandrare till eftergymnasiala yrkesutbildningar. Under litet mer än tjugo år hade detta system byggts upp och etablerats i alla svenska kommuner (Johansson \& Salin 2007, s. 3).

1982 fick Komvux en egen läroplan, och två år senare (1984) infördes en vuxenutbildningslag. Båda avskaffades dock i samband med 1990talets decentraliserings- och kommunaliseringssträvanden. Ansvaret för skolan flyttades över från staten till kommunerna. Komvux fick åter en läroplan gemensam med ungdomsgymnasiet. Arbetsmarknadsutbildningen räknades alltjämt inte som en del i det formella utbildningssystemet, utan primärt en del av arbetsmarknadspolitiken. Den statligt finansierade arbetsmarknadsutbildningen gjordes om till en intäktsfinansierad uppdragsutbildning, och är sedan 1993 organiserad som ett statligt ägt bolag. 1980-talets reformstrategi innebar satt den kompetensgivande vuxenutbildningen fick alltmer tydliga socialpolitiska förtecken. Delvis nya grupper rekryterades, och strategin var att ge människor grundläggande intel- 
lektuella resurser för ett nytt avstamp i livet. En tydlig förändring är övergången från undervisning på kvällstid, till undervisning förlagd till dagtid. Utbildning på gymnasial nivå fick inte längre expandera. Under 1980-talet tonar insatser riktade mot enskilda grupper ner, och viss återgång sker till mer generella åtgärder som under 1960-talet. Anslagen till vuxenutbildningen stagnerar. Mot slutet av 1980-talet sattes åter relationen mellan vuxenutbildning och arbetslivet i förgrunden. $\mathrm{Nu}$ handlade det inte längre om arbetslivets demokratisering, utan om vuxenutbildningens betydelse för arbetslivets förändringar och till nytta för ekonomisk tillväxt.

Det tidiga 1990-talet var en period av djup ekonomisk kris. Arbetslösheten steg dramatiskt under några få år. Decenniet inleds med en styrningsreform, där relationen mellan vuxenutbildning och gymnasieskola åter stärks på bekostnad av den särskilda läroplanen för den kompetensgivande vuxenutbildningen. Målstyrning införs som styrningsprincip. Statsmakten ägnar åter ökat intresse för vuxenutbildningen. Regeringen tillsatte en kommitté om ett nationellt kunskapslyft för vuxna. Några år innan det femåriga Kunskapslyftet sjösattes 1997, anslog Regeringen en miljard kronor för en extrasatsning inom vuxenutbildning. Syftet var att halvera arbetslösheten. I mångt och mycket kan man betrakta Kunskapslyftet som ett sätt att organisera förnyelse av vuxenutbildningen (Lumsden Wass 2004) och där kommunerna fick stort inflytande när det gällde hur detta skulle gå till.

På den politiska policyskapande nivån i Sverige, tar man stort intryck av debatten inte bara inom EU, utan även inom UNESCO, OECD och Europarådet. Redan 1972 publiceras UNESCO-rapporten "Learning to Be", med den dåvarande franske utbildningsministern Edgar Faure som redaktör (Faure 1972). År 1996 gav UNESCO ut rapporten „The Treasures Within“ ut med Jacques Delors som huvudredaktör (Delors 1996). År 1995 publicerade EU vitboken „Teaching and learning: Towards the Learning Society“ (EU 1995). Begreppet livslångt lärande kom alltmer att prägla de nationella policydebatterna. Policynivån präglades alltmer av begreppen informellt lärande (lärande utan att någon tydlig undervisningssituation föreligger), icke-formellt lärande (utbildning organiserad vidd sidan av utbildningsväsendet) och formellt lärande (utbildning inom det reguljära utbildningsväsendet). 


\section{Referencer}

Ahlén, S. (1985). Ds U 1985:10. Vuxenutbildning - 1970-taletsreformer. En utvärdering Arbejdsministeriet, Undervisningsministeriet \& Finansministeriet (1999). Mål og midler i offentligt finansieret voksen- og efteruddannelse. Albertslund: Schultz Information.

Barne-, likestillings- og inkluderingsdepartementet (1981). Stortingsmelding $n r .45$ (1980-81) Utdanning og arbeid. Oslo: Barne-, likestillings- og inkluderingsdepartementet.

Danish Ministry of Foreign Affairs (2010). Factsheet Denmark. Denmark - an overview. Copenhagen: Danish Ministry of Foreign Affairs.

Delors, J. Ed. (1996). The Treasures Within. UNESCO.

Elvander, N. (2002). „The Labour Market Regimes in the Nordic Countries: A Comparative Analysis." In: Scandinavian Political Studies, Vol. 25, No. 2.

EU (1995). Teaching and Learning - Towards the Learning Society. White Paper on Education and Training. Lanham: Bernan Associates.

Faure, E., et. al. (1972). Learning to be. The world of education today and tomorrow. Paris: UNESCO.

Folketinget (1984). Forslag til folketingsbeslutning om et 10 punkts program for voksenundervisning og folkeoplysning. Beslutningsforslag nr. B 114, fremsat den 4. april 1984 af Ole Vig Jensen (RV), Bilgrav-Nielsen (RV), Estrup (RV) og Niels Helveg Petersen (RV).

Fransson, A. \& Lunquist, O. (1988). Komvux rekryterar rätt! En jämförelse av rekryteringsmönstret till etapp 1 höstterminenerna 1980 och 1987. Publikationer från institutionen för pedagogik 1988:04. Göteborgs universitet.

Henning-Loeb, I. (2007). Utveckling och förändring i kommunal vuxenutbildning: En yrkeslivshistorisk ingång med berättelser om lärbanor. Göteborg: Acta Universitatis Gothoburgensis. Gothenburg Studies in Educational Sciences 237.

Johanson, J. (2002). Fra beskæftigelseslejr til moderne AMU-Center - historien om AMU Hoverdal. Retrieved from http://www.hoverdal.dk/Generel/historie.htm

Johansson, K. \& Salin, S. (2007). Formell vuxenutbildning. Utveckling och förutsättningar. Hässleholm, Härnösand och Norrköping: Nationellt centrum för flexibelt lärande. Särtryck.

Kirke- og undervisningsdepartementet (1989). Stortingsmelding nr. 43. Mer kunnskap til flere. Oslo: Kirke- og undervisningsdepartementet.

Klinkby, E. (2004). Historien om VUC - fra teknisk forberedelse til livslang læring. Frederiksberg: Roskilde Universitetsforlag.

Korsgaard, O. (1997). Kampen om lyset. Dansk voksenoplysning gennem 500 år. Copenhagen: Gyldendal.

Korsgaard, O. (1999). Kundskabskapløbet - uddannelse i videnssamfundet. København: Gyldendal.

Kunnskapsdepartementet (1976). Lov om voksenopplæring (voksenopplæringsloven), LOV-1976-05-28-35. Oslo: Kunnskapsdepartementet.

Larson, A. (1994). VUS - effekten på længere sigt. Evaluering af Lov om voksenuddannelsesstøtte. København: Forskningscenter for Voksenuddannelse. 
Larsson, U. (2003). Olof Palme och utbildningspolitiken. Hjalmarsson \& Högberg.

Lassen, M. (1998). Da søstre lod våbnene lyne - om uddannelsespolitik i LO-familien siden 1960. (Arbejdspapir No. 1998:1). Ålborg: Aalborg Universitet, Institut for Økonomi, Politik og Forvaltning.

Lov om tilskud i anledning af ungdomsarbejdsløsheden. Lov nr. 186 af 20. maj 1933.

Lumsden Wass, K. (2004). Vuxenutbildning i omvandling. Kunskapslyftet som ett sätt att organisera förnyelse. Göteborg: Acta Universitatis Gothoburgensis. Gothenburg Studies in Educational Sciences.

Mailand, M. (2009). „Perspektiven des skandinavischen korporatismus Dänemark und Norwegen im Vergleich.“ In: WSI-Mitteilungen, 2009(1).

Milana, M., \& Sørensen, T. B. (2009). „Promoting democratic citizenship through non-formal adult education: The case of Denmark." In: Scandinavian Journal of Educational Research, 53(4), 347-362.

Ministry of Education (1997). The joy of learning. A national strategy for lifelong learning. Committee report: 1997, 14. Helsinki: Ministry of Education.

Mørch Jacobsen, K. (1982). Voksenundervisning - for hvem til hvad? København: Nordisk Ministerråd.

Nordisk Ministerråd (1982). Voksenundervisningen i Norden. København: Nordisk Ministerråd.

Nordisk Ministerråd (1995). Guldtavlerne i græsset - livslanglæring for alle, nr. 1995:002. København: Nordisk Ministerråd.

Norges offentlige utredninger (1988). Med viten og vilje. NOU 1988:28. Oslo: Norges offentlige utredninger

OECD (2001a). Thematic Review on Adult Learning: Denmark. Background Report. Paris: OECD.

Payne, J. (2006). „The Norwegian competence reform and the limits of lifelong learning." In: International Journal of Lifelong Education, Vol. 25, No. 5.

Raunio, T. (2007). „Always One Step Behind? National Legislatures and the European Union“, In: Government and Opposition, Vol. 34, Issue 2.

Ringsted, M. (2002). „AMU i en brydningstid.“ Uddannelse, (9). Retrieved from http://udd.uvm.dk/200209/index.htm?menuid=4515

Rubenson, K. Tuijnman, A. \& Wahlgren, B. (1999). „Från kunskapslyft till en strategi för livslångt lärande: ett perspektiv på svensk vuxenutbildningspolitik. "I: SOU 1999:141. Från Kunskapslyftet till en strategi för livslångt lärande - Ett perspektiv på svensk vuxenutbildningspolitik. Kommittén om ett nationellt Kunskapslyft för vuxna. Stockholm.

Runesdotter, C. (2010). I otakt med tiden?: folkhögskolorna i ett föränderligt fält. Göteborg : Acta Universitatis Gothoburgensis, Gothenburg studies in educational sciences, 296.

Simonson, B. (1988). Arbetarmakt och näringspolitik. Arbetslivsfonden.

SOU 1948:27. 1946 års skolkommissions betänkande med förslag till diskussion. Stockholm.

SOU 1959:45. 1955 års universitetsutredning. Universitet och högskolor i 1960-talets samhälle: riktlinjer och förslag till utbyggnad. Stockholm: Utbildningsdepartementet. 
SOU 1962:5. Vidgad vuxenutbildning på gymnasiestadiet. Studiesociala utredningen. Stockholm: Ecklesiastikdepartementet.

SOU 1965:60. Vuxenutbildning i gymnasium och fackskola. 1960-års gymnasieutredning. Stockholm: Ecklesiastikdepartementet.

SOU 1966:3. Yrkesutbildningen. Yrkesutbildningsberedningen. Stockholm: Ecklesiastikdepartementet.

SOU 1973:2. Högskolan: Betänkande av 1968 års utbildningsutredning (U 68). Stockholm: Utbildningsdepartementet.

Statistics Iceland (2011). „Population development 2010.“ Statistical series 96(18). Reykjavik: Statistics Iecland.

Thång, P-O. (2006). „Vuxenutbildningens framväxt.“ I: Larsson, S. \& Olsson, L-E. Om vuxnas studier. Lund: Studentlitteratur.

Tøsse, S. (2005). Folkeopplysning og vaksenopplæring. Idear og framvekst gjennom 200 år. Oslo: Didakta Norsk Forlag.

Undervisningsministeriet (1989). Lov om voksenuddannelsesstøtte, Lov nr. 336 af 24. maj 1989. København: Undervisningsministeriet.

Undervisningsministeriet (2000). Lov om åben uddannelse (erhvervsrettet voksenuddannelse) m.v. , Lov nr. 508 af 30. juni 2000. København: Undervisningsministeriet.

Undervisningsministeriet (2001a). Taxametersystemet for de videregående uddannelser. Rapport fra undervisningsministerens Idé- og Perspektivgruppe. København: Undervisningsministeriet.

Undervisningsministeriet (2001b). Rapport fra udvalget om de almene uddannelser. København: Undervisningsministeriet.

Utbildningsdepartementet (1975). Regeringens proposition om vidgad vuxenutbildning samt studiestöd till vuxna m.m. Prop. 1975:23. Stockholm: Utbildningsdepartementet.

Østergård, U. (2006). „Denmark: A Big Small State - The Peasant Roots of Danish Modernity.“ In J. L. Campbell, J. A. Hall \& O. K. Pedersen (Eds.), National Identity and the Varieties of Capitalism. Copenhagen: DJØF Publishing. 


\section{nordon}

\section{Nordisk ministerråd}

Ved Stranden 18

DK-1061 København K

www.norden.org

\section{Effektive strategier for livslang læring i de nordiske lande}

I tråd med Lissabonstrategien er det de nordiske landes mål, at øge befolkningernes deltagelse i voksenog efteruddannelse, særligt blandt kortuddannede og to-sprogede.

Det er baggrunden for undersøgelsen af landenes kompetencepolitiske indsatser til fremme af livslang læring for alle. Undersøgelsen fokuserer på samarbejdet mellem myndigheder og arbejdsmarkedets parter, samspillet mellem uddannelsesinstitutioner og virksomheder, samt indsatser for at styrke voksnes nøglekompetencer.

De nordiske strategier for livslang læring har flere fællestræk, herunder:

- samarbejde mellem de uddannelses- og de arbejdsmarkedspolitiske myndigheder

- $\emptyset g e t$ fokus på realkompetencer, vejledning og rådgivning

- tendens til mere offentlig regulering og frivillig koordinering

Rapporten afsluttes med anbefalinger til opfølgende arbejde og til videre analyser på området. 